\title{
Who is 'New Zealand'? \\ Publics in Aotearoa/New Zealand General Election Discourse
}

\author{
By lan Anderson
}

A thesis submitted to the Victoria University of Wellington in fulfilment of the requirements for the degree of Masters in Media Studies

Victoria University of Wellington

2016 



\title{
Acknowledgements
}

Each individual relies on a vast social web. It is impossible to name everyone who made this work possible.

With that in mind, and in alphabetical order, I would like to acknowledge:

\author{
Judith and Bruce Anderson \\ Hera Lindsay Bird \\ Sue and Bill Bradford \\ Anita Brady \\ Vita Bryant \\ Robbie Bunker \\ Uther Dean \\ Don Franks \\ Sandra Grey \\ Kassie Hartendorp \\ Gayaal Iddamalgoda \\ Sarah Johnstone \\ Robyn E Kenealy \\ Alison Laurie \\ Bill Logan \\ Heleyni and Marika Pratley \\ LaQuisha Redfern \\ Benedict Joseph Reid \\ Ruth, Emily and Andrew Russell \\ Dylan Sofa \\ Annette Sykes \\ Fetuolemoana Tamapeau \\ Rangimoana Taylor \\ Teresia Teaiwa \\ Sonny Thomas \\ Peter Thompson \\ Leilani Viseisio \\ Jenny White
}




\title{
Contents
}

\author{
Abstract (iii) \\ Figures and Tables (p. iv) \\ Introduction (p. v)
}

Chapter 0: Historicist and Analytical Methodology (p. xii)

Chapter 1: Institutionalism and Right-Wing Populism (p. 1)

Chapter 2: Recognition of the Subaltern (p. 22)

Chapter 3: Political Convergence and the Production of Nonpublics (p. 38)

Conclusion (p. 64)

Works Cited (p. 72)

Appendix: Coding schedule (p. 97) 


\begin{abstract}
2011 saw the lowest voter turnout in Aotearoa/New Zealand since women won the right to vote (Vowles, 2014). This decline in participation aligns with trends elsewhere in the Anglosphere (Ailes, 2015; Hansard, 2015). This organic crisis poses new questions for notions of the 'public sphere' and 'publics' - the forms of political engagement with citizens in a mass-mediated society. Fraser (1990) contends that in theorising the "limits of actually existing late capitalist democracy" (p. 57), we need a notion of pluralised and contesting 'publics' (ibid). The project asks how political parties named the 'public' (or publics) in the 2011 and 2014 Aotearoa / New Zealand General Elections. In order to consider the dominance of these political articulations, research will also consider whether these invocations of 'the public' found coverage in the national press. This is not intended as a sociological examination of actually existing publics, but an examination of dominant encoding (Hall, 2001). This analysis tests the thesis that dominant cross-partisan electoral discourses defined the 'public' in terms of dual identification with productive work and capital, in opposition to named subaltern publics. This formulation suggests that workers are called to identify with capital, following from Gramsci's (2011) theorisation of bourgeois hegemony. Research begins with a content analysis of party press releases and mainstream coverage during the 2011 \& 2014 General Elections, when official discourses hailing 'the public' are intensified. Content analysis quantifies nouns used for publics - for example, 'taxpayer', 'New Zealander', or even 'the public'. From this content analysis, the project proceeds to a critical discourse analysis, which seeks to historically contextualise and explain the patterns in content. Reworking Ernesto Laclau's (2005a) theorisation of populism to factor in the left/right axis (which Laclau considered outmoded), this critical discourse analysis considers what 'public' alliances are articulated, and what political programmes these articulations serve.
\end{abstract}




\section{Figures and Tables}

Figure 1: Levi Strauss' Zero Value (p. xi)

Figure 2: Harvey's historical "moments" (p. xiii)

Figure 3: Harvey's historical moments, my emphasis (p. xiii)

Figure 4: Three competing political frameworks: Institutionalism, Left-Wing Populism and Right-Wing Populism (p. xvii)

Figure 5: Categories for non-voting (p. xxxvii)

Figure 6: Party pronouns 2011-2014 (p. 4-5)

Figure 7: Power prices (p. 16)

Figure 8: National and ethnic terms, party releases 2011-2014 (p. 17)

Figure 9: House Prices vs Income (p. 19)

Figure 10: 'Māori'/'Pakeha' 2011-2014 (p. 24)

Figure 11: 'Women'/'Men' 2011-2014 (p. 28)

Figure 12: 3 Most Common Economic Terms (p. 31)

Figure 13: Asset sales "bonanza" (p. 33)

Figure 14: Economic terms, party releases 2011 (p. 37)

Figure 15: Major party references to minor parties, 2011-2014 (p. 40)

Figure 16: Political ideology, party releases 2011-2014 (p. 41)

Figure 17: Parties and leaders, coverage by press 2011 (p. 44)

Figure 18: Parties and leaders, coverage by press 2014 (p. 44)

Figure 19: NZ Herald conceptions of democracy (p. 47)

Figure 20: Gender/sex/sexuality, party releases 2011-2014 (p. 50)

Figure 21: Religion, party releases 2011-2014 (p.50) 


\begin{tabular}{|c|c|c|c|}
\hline Research question(s) & Data & Method & Theoretical framework \\
\hline $\begin{array}{l}\text { How did political parties } \\
\text { invoke the 'public' (or } \\
\text { publics) in the } 2011 \text { and } \\
2014 \text { Aotearoa / New } \\
\text { Zealand General } \\
\text { Elections? }\end{array}$ & $\begin{array}{l}\text { All parliamentary party } \\
\text { press releases and } \\
\text { national newspaper } \\
\text { coverage over the last } \\
\text { two weeks of } 2011 \& \\
2014 \text { General } \\
\text { Elections. }\end{array}$ & $\begin{array}{l}\text { Content analysis } \\
\text { identifying nouns. }\end{array}$ & $\begin{array}{l}\text { Context of "democratic } \\
\text { deficit," question of 'publics' } \\
\text { in this crisis of democracy. }\end{array}$ \\
\hline $\begin{array}{l}\text { What degree of } \\
\text { representation did these } \\
\text { articulations find in the } \\
\text { national press? }\end{array}$ & $\begin{array}{l}\text { Selected 'typical' and } \\
\text { 'atypical' releases and } \\
\text { articles. }\end{array}$ & $\begin{array}{l}\text { Critical discourse } \\
\text { analysis. }\end{array}$ & $\begin{array}{l}\text { Hegemonic constitution of } \\
\text { 'peoples'. }\end{array}$ \\
\hline
\end{tabular}

\section{Introduction}

2011 saw the lowest voter turnout in Aotearoa/New Zealand since women won the right to vote (Vowles, 2014). The Civics and Media Project, a "non-partisan, cross-institutional initiative", suggests that "civic engagement in New Zealand is under threat" (Civics and Media Project, 2016). Declining public participation in civic institutions has been termed a "democratic deficit" (Beetham 2002; Grey and Sedgwick 2013). This local decline of participations aligns with trends elsewhere in the Anglosphere (Ailes, 2015; Hansard, 2015). This crisis poses new questions for notions of the 'public sphere' and 'publics' - how citizens engage politically in a mass-mediated society. Fraser (1990) contends that in theorising the "limits of actually existing late capitalist democracy" (p. 57), we need a notion of pluralised and contesting 'publics' (ibid). Recent international trends have seen the emergence of new populist movements opposing neoliberalism. These include left-reformist electoral campaigns; Syriza's election in Greece, Bernie Sanders' campaign in the US and Jeremy Corbyn's successful leadership bid in UK Labour (Dean, 2016, p. 1-25). Conversely, right-wing populist campaigns have found new electoral 
currency; UKIP's Brexit campaign in the UK, Trump's campaign in the US. My research considers whether these international populist trends have found mainstream expression in Aotearoa/New Zealand electoral discourse, using an adaptation of Ernesto Laclau's (2005a) framework for examining populism, factoring in the left/right axis which Laclau considered outmoded. This research project seeks to identify how specific 'publics' are invoked within political frameworks such as populism. The project asks how political parties named the 'public' (or publics) in the 2011 and 2014 Aotearoa / New Zealand General Elections, as elections are a period of intensified appeals to publics. In order to consider the dominance of these political articulations, research also considers whether these invocations of 'the public' were covered in the national press. This is not intended as a sociological examination of actually existing publics, but an examination of dominant encoding (Hall, 2001). This analysis tests the thesis that dominant cross-partisan electoral discourses defined the 'public' in terms of dual identification with productive work and capital, in opposition to named subaltern publics. This formulation suggests that workers are called to identify with capital, following from Gramsci's (2011) theorisation of bourgeois hegemony. Research begins with a content analysis of party press releases and mainstream coverage during the 2011 \& 2014 General Elections, a period when dominant political actors seek consent from their 'publics'. Content analysis quantifies nouns used for publics - for example, 'taxpayer', 'New Zealander', or even 'the public'. From this content analysis, the project proceeds to a critical discourse analysis, which seeks to historically contextualise and explain the patterns in content. This critical discourse analysis considers what alliances are articulated, and what political programme these articulations serve.

\section{Political background}

My examination of local manifestions of the 'crisis in democracy' draws on normative notions of the "public sphere" or pluralised "publics." The notion of 'publics' is informed by Nancy Fraser's (1990) complication of Jurgen Habermas' public sphere theory. The 'public sphere' was initially theorised as a space of common democratic deliberation, where inequalities were bracketed, and which has been disrupted by 'refeudalisation' under late capitalism (Habermas, 1962). Critical scholars contend that the 'public sphere' in Aotearoa/New Zealand is undermined by increasing privatisation of media, with a lack of support for critical journalism undermining the space for public participation (Hope, 1996; Hope, 2012; Thompson, 2011). Conversely, many argue that the 'public sphere' never truly existed, as it 
involved exclusions from its inception - along class, race, gender and national lines (Fraser, 1990). Fraser concedes that the public sphere, as an egalitarian space, has never truly existed, but upholds it as a normative ideal (p. 78-79). Her work seeks to theorise "the limits of democracy in late capitalist societies" (p. 56), with the normative aim of conceiving a "post-bourgeois public sphere" (p. 58). For Fraser, the "bourgeois public was never the public" (p. 61), but was rather disrupted by "subaltern counterpublics" from the start (p. 67-68) Although focusing on dominant bourgeois discourse, rather than "subaltern counterpublic" discourse, my analysis considers the hailing of 'publics' along pluralised lines - national, ethnic, gendered et al. This analysis also considers the disavowed 'nonpublics' in dominant discourse. The 'nonpublic' was coined to consider power relations deemed outside the 'public sphere', particularly class relations in the factory, not considered a space for democratic deliberation (Negt and Kluge, 1972, p. 39). My analysis uses the terms 'public' and 'nonpublic' more broadly in reference to the way communities are invoked or disavowed in dominant discourse, for example the term 'foreigner' which disavows a community as outside the national 'public'. With record-high nonvoters in Aotearoa/New Zealand recently dubbed the "missing million" (Williams, 2014), the concept of 'nonpublics' may assist in considering relationships between political discourse and growing disenfranchisement.

My research also examines whether recent international populist trends have found expression in Aotearoa/New Zealand electoral discourse. This project's consideration of potential populist articulation draws on Gramscian theorist Ernesto Laclau's (2005a) framework for understanding 'populist reason'. For Laclau, the 'people' is the "central protagonist of politics (p. 249). Populism in constituting a 'people' is not a particular kind of political movement, or a pejorative term, but is rather necessary to various degrees for any political articulation (p. 117). Jovanovski (2016) calls Laclau's framework into question, examining populist projects in Southern Europe, and dubs these projects a form of 'radical centrism' that fail to challenge the structural nature of capitalism. Gurhanli (2013) also contends that populist figures like Italy's Berlusconi trouble Laclau's thesis, as they do not pose a structural challenge to the prevailing regime. Taking these critiques of Laclau's 'centrism' into account, my analysis considers to what degree populist articulations pose a challenge to the prevailing regime. Laclau (2005a) defines "populism" in contrast to "institutionalism" - while institutionalism limits discourse to forms that keep social structures intact, populism polarises discourse between the 'people' and some opposing group 
(p. 81). As neoliberalism is the prevailing organisation of capitalism in Aotearoa/New Zealand (Kelsey, 2016), my analysis defines 'institutionalist' articulations as those which seek to keep neoliberalism intact, while populist articulations polarise 'the people' with the neoliberal elite. However, in addition to Laclau's populist/institutionalist axis, my analysis factors in the left/right axis which Laclau considered outmoded..$^{1}$ In particular, my methodology distinguishes between left-wing and right-wing populism, which Laclau (2005a) considers less important than the moment of "radical anomie" which is not specific to left or right-wing politics (p. 88). The difference between left-wing and right-wing populism lies in the nature of 'the people' constituted to challenge the neoliberal elite. Whereas left-wing populism defines its 'people' through subalternity (wherever power exists a challenge will emerge), right-wing populism defines its 'people' through the nation-state. As the nation-state is a cross-class alliance, this formation cannot fundamentally challenge capitalism. As Indian Marxist Jairus Banaji (2016) argues in relation to India's right-wing "communalist" movement, neoliberalism and nationalism both serve rightwing purposes, each disarming the working class in different ways:

Neo-liberalism disarms the working class economically, destroying its cohesion in an industrial, economic sense. Racism, communalism and nationalism... do the same in more insidious ways, destroying the possibility of the working class ever acquiring a sense of its own solidarity and of what it really is (Banaji, 2016).

For Laclau (2005a), a 'people' is constituted through demands (p. 74-75). My analysis frames demands through Fraser's (2005) three-dimensional framework of (cultural) recognition, (economic) redistribution and (political) representation (p. 305-306). For example, the slogan 'recognise the union, pay a living wage'. Workers are recognised as a people, or a public, with legitimate demands. Political representation occurs through the union. Finally, the slogan demands economic redistribution through

1

In the 1970s, Laclau (1977) distinguished between left-wing and right-wing populism, defining right-wing populism as that which supports the dominating class (p. 173). However, my own definition of right-wing populism (as specifically nationalist) contradicts Laclau's politics, as Laclau supported Peronism (Keucheyan, 2015), a deeply nationalist project. I also consider his early definition of right-wing populism (that which supports the dominating class) to be a tautological truism within Marxist politics, lacking adequate explanatory value. Furthermore, this was before his epistemological break with classical Marxism (Laclau and Mouffe, 1985/2001). His post-Marxist framework for analysing populism (Laclau, 2005a), which my analysis employs in considering alliances, does not distinguish between left-wing and right-wing populism. My taxonomy is therefore distinct both from Laclau's 1977 definition and his 2005 non-definition of 'right-wing populism.' 
improved wages. A working-class 'people' is thus constituted through demands. In contrast, political actors may appeal to members of the same group through the slogan 'stop beneficiaries from ripping off the taxpayer'. The slogan makes a demand for redistribution of wealth, away from welfare recipients. The slogan also implies that the state is failing in its job of representing the taxpayer, by spending money wastefully. Finally, the taxpayer is recognised as a legitimate, productive citizen. The 'taxpayer' is a cross-class coalition - theoretically every citizen must pay taxes, but implicitly only 'productive' citizens do (an ironic mystification, given that capitalists have more capacity to evade taxes than beneficiaries). Therefore unlike the previous working class slogan, a cross-class 'people' is constituted in opposition to subalterns. A people is defined not only by its sociological position, but its political allegiance, which is constituted through demands.

\section{Methodology}

My analysis begins with a content analysis of a) party press releases and b) mainstream election coverage. Kimberley Neuendorf (2002) defines content analysis as a 'scientific' method, a quantitative method that can be reproduced or verified (p. 2). However, content analysis cannot necessarily identify how audiences may respond (Newbold et al 2002, p. 80). In Hall's (2001) framework, my analysis is more focused on the moment of hegemonic 'encoding' than audience 'decoding', as encoding (or text production) is a locus of institutional power (p. 189-212). However, some comparisons between electoral discourse and public behaviour are discussed - through polls, final vote, and surveys of nonvoters, as an indicative rather than conclusive measure. A fuller analysis of audience response requires a more ethnographic approach, which is outside the scope of this project.

My content analysis compares party press releases with mainstream press coverage, to identify which formal political discourses of 'the public' are structurally privileged. The content consists of two batches; press releases by parties with seats in parliament (National Party, Labour Party, Green Party, New Zealand First, Māori Party, Internet-MANA, ACT, United Future), and front page electoral coverage in major national newspapers (NZ Herald, Dominion Post). Nzherald.co.nz and Stuff.co.nz (website of the Dominion Post) are among the top 10 ranked websites in New Zealand in terms of hits (Alexa, 2014), making them platforms for dominant political discourse. The analysis seeks nouns for 'publics' across all sources, applying a consistent coding schedule to all content (Appendix). This analysis is restricted 
to the last two weeks of the 2011 and 2014 General Elections, both to study official discourses of the 'public' in a period of democratic deficit, and to ensure available comparable data (especially given the wide range of parties selected). I draw press releases from the archives of party websites, however the extent of these archives is inconsistent. Where archives are lacking, I contact the parties for press releases over the defined period. Finally, Scoop is used as a last resort, as an online source which prints all press releases unedited.

My content analysis began with a draft list of nouns intended to correspond to 'publics' or 'nonpublics' e.g. 'New Zealander', 'worker', 'taxpayer', 'foreigner'. After manually checking this list of nouns against the content, the coding schedule is expanded to incorporate unanticipated terms. Once reworked, the coding schedule is consistently applied across all content. The coding schedule includes 14 categories (Ethnic, Economic, Gendered...) and 213 individual nouns (Appendix). I quantify nouns, and make brief qualitative notes for future reference; e.g. whether 'families' are associated with violence or nurturance.

Content analysis generally seeks to group individual units of texts into broader categories, for ease of analysis (Stemler 2001). However my unit of analysis, the specific noun, must be treated individually. The terms 'taxpayer' and 'beneficiary' could sociologically refer to the same person (as beneficiaries pay consumption taxes), yet the ideological inflections of these terms are distinct. Therefore while broader categories of analysis are certainly employed, the individual nouns (or units) are more crucial to this analysis. Quantitative analysis is conducted manually, as the batch is relatively small and requires some qualitative assessments: e.g. whether 'Kiwi' refers to the people, the bird or the bank.

This analysis produces the background needed for an informed qualitative analysis of the discursive construction of 'the public'. Whereas the content analysis is only drawn from the last two weeks of the 2011 and 2014 General Elections, examples for critical discourse analysis are drawn from a wider pool of parliamentary coverage, to provide context and comparisons.

The presentation of findings is broken into three chapters. Each chapter outlines an aspect of the quantiative findings, before proceeding to critical discourse analysis of selected examples. The first chapter works to characterised the discourse of the two major parties, National and Labour - including 
any commonalities and divergences between them. The second chapter considers whether dominant parties recognise subaltern groups, and whether any articulations of subaltern agency are visible in the texts. Finally, the third chapter considers the relationship between major parties and national press, particularly in terms of constructing the national political 'centre'. This critical discourse analysis seeks to test the hypothesis that dominant cross-partisan discourses defined the 'public' by dual identification with productive work and capital, in opposition to named subaltern publics. 


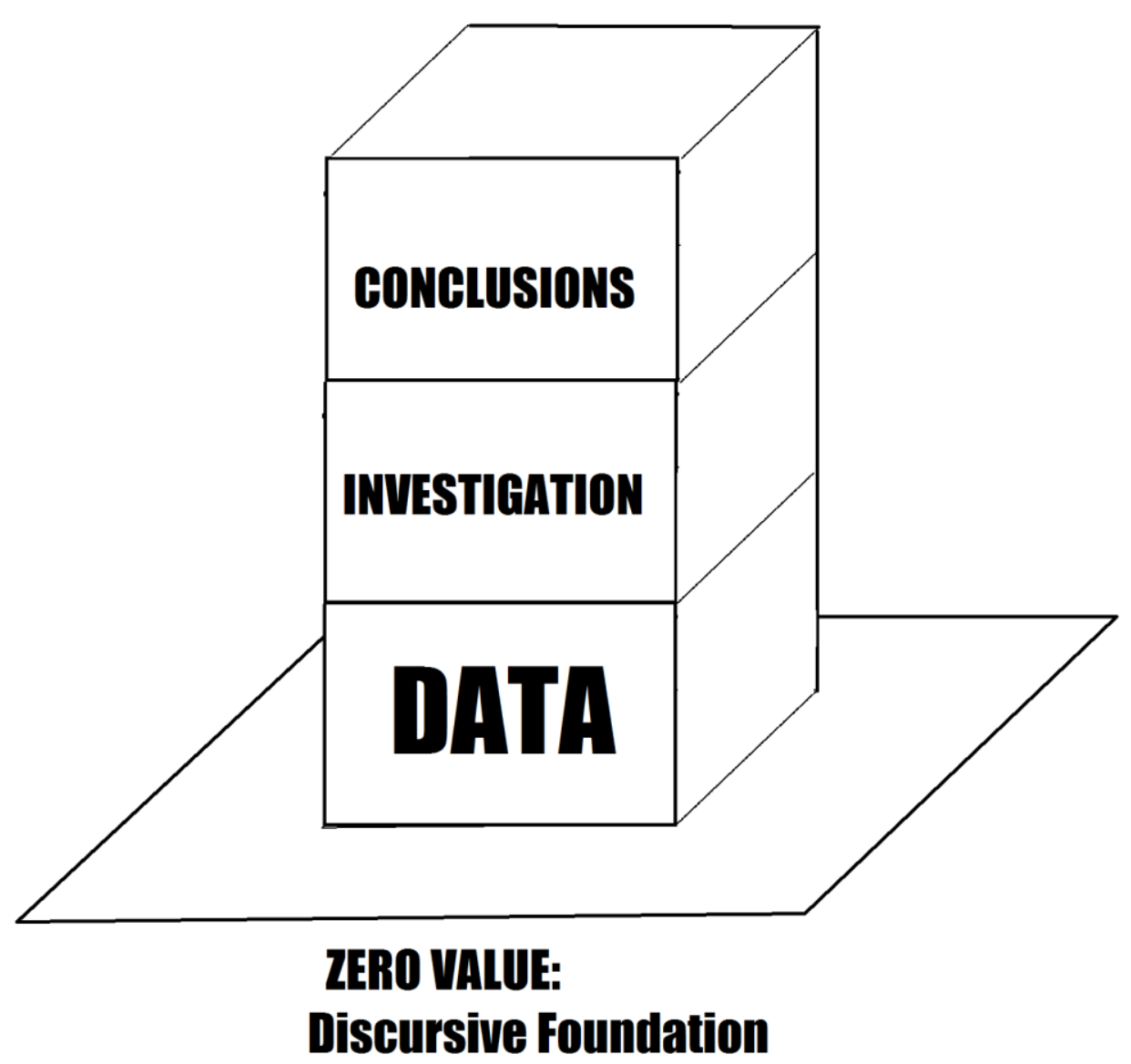

Figure 1

\section{Chapter 0: Historicist and Analytic Methodology}

This chapter outlines three key aspects of my methodology and theoretical framework; 3) a content analysis of party press releases and national press coverage, 2) contextualised by local historical background, 1) understood through Communist Theory. Anthropologist Levi-Strauss (1963) suggested that certain "institutional forms," such as the "father," may have a "zero value" - they provide the structure of structure, the meaning that allows meaning (p. 35, 159). Before my empirical investigation into bourgeois discourse, I first establish the 'zero-level' of my investigation; the prior discursive elements that allow me to speak (Figure 1). Building on the work of Marxists and other critical theorists, this project assumes the global dominance of white-supremacist capitalist patriarchy (bell hooks; 1981), its localised form in colonisation of Aotearoa / New Zealand (Evan Poata-Smith; 1997), and a recent neoliberal phase of capitalism defined by flexibilisation and privatisation (Kelsey, 2016). My analysis investigates how political actors within this regime hail a people, or public, and whether this call serves to reproduce or interrupt the prevailing discursive regime. 


\section{Communist Theory}

My analysis is informed by prior Marxist critique. Marxism is often rebuked for an overemphasis on economic determination (see Laclau and Mouffe, 1985/2001). As Engels conceded in a letter to J Bloch, this stress on the economic was partly a compensation for perceived limitations in the left literature of the time:

Marx and I are partly responsible for the fact that at times our disciples have laid more weight upon the economic factor than belongs to it. We were compelled to emphasize this main principle in opposition; to our opponents who denied it, and there wasn't always time, place and occasion to do justice to the other factors in the reciprocal interaction (1890/2006).

In place of this 'economism', Laclau and Mouffe (1985/2001) conversely elevate ideological hegemony (or discourse) as the "precise terrain" for social relations (p. 67). Similarly Foucault (1972) elevates discourse analysis as a method in itself, rejecting 'allegorical' readings such as historicism (p. 138-139). While drawing heavily on Laclau and Foucault's work, I suggest this elevation of discourse throws out the baby with the bathwater ${ }^{2}$ - as Boucher (2008) contends in a critique of post-marxism, discourse "becomes the quasi-transcendental ground for an expanded conception of politics and history" (p. 87). Discourse analysis becomes a totalising theory, subordinating economic determination. As David Harvey (2005) suggests, elevating any moment as solely determining is potentially "dangerous" or at least misleading (p. 194-196).

2 In defence of clichés: The concept of recovering a baby from dirty bathwater strikes me as a powerful metaphor for grappling with often complex, contradictory intellectual history - separating the value of anticapitalism from the sometimes misguided prejudices of its theorists, for example. I find this metaphor particularly powerful because its flipside, the cliché, is a horrifying Gothic metaphor: imagine the parent or caregiver accidentally sending a baby to the ground, out the window, down the drain. If we chuck out the baby with the bathwater, is there still a chance to recover the baby? Have we permanently injured the baby, and can they still lead a healthy life? Or is the baby irrecoverable? Can we live with ourselves when we realise what we've done?

In American revolutionary Thomas Carlyle's words, supporting the abolition of slavery, but asking whether its abolition may lead to new forms of economic precarity: "The Germans say, "you must empty-out the bathingtub, but not the baby along with it." Fling-out your dirty water with all zeal, and set it careening down the kennels; but try if you can keep the little child!" (Carlyle, 1849; quoted in Wilton, 2007). 
xiv

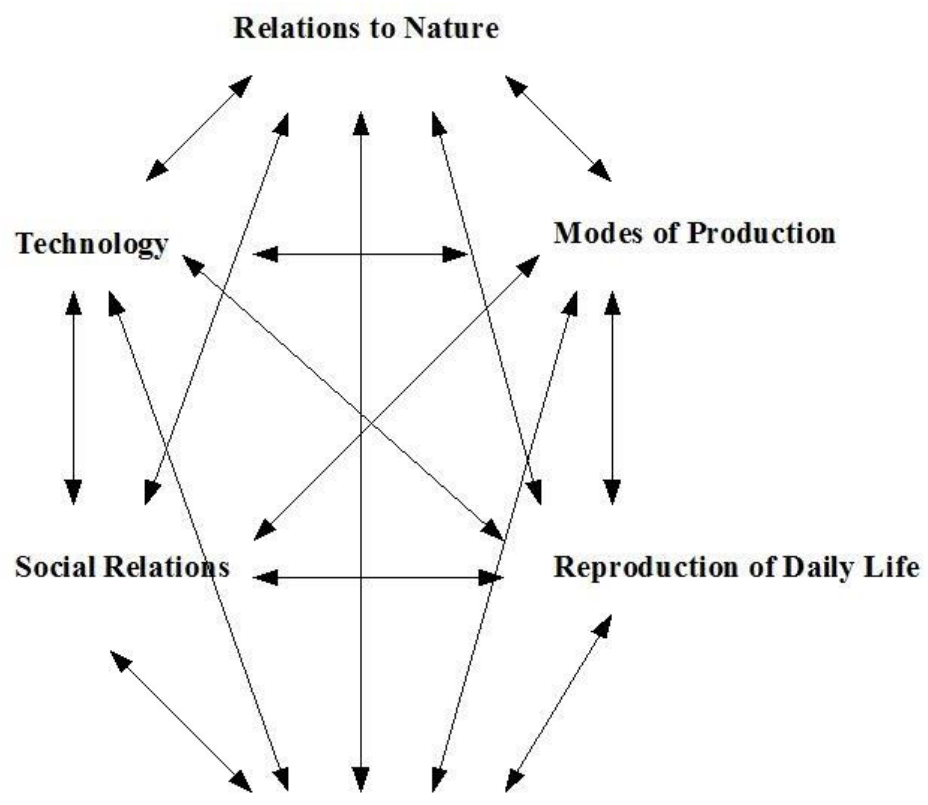

Mental Conceptions of the World

(The Semiotic)

\section{Figure 2}

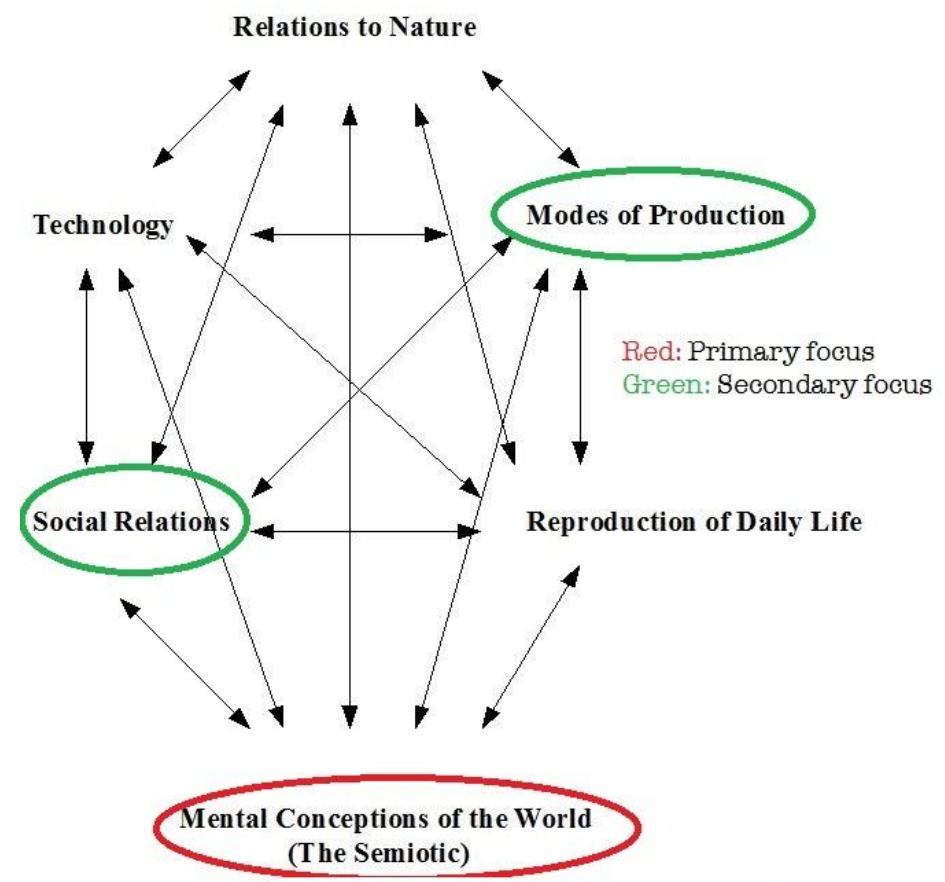

Figure 3

David Harvey (2005) draws six 'moments' of historical determination out of Marx's work - Relations to Nature, Modes of Production, Technology, Social Relations, Reproduction of Daily Life, Mental Conceptions of the World / The Semiotic (p. 193-196; Figure 2). Each of these moments can serve to 'reveal' the others (p. 194-196). Harvey's model contrasts both with Laclau and Mouffe's elevation of 
discourse, and the classical Marxist ${ }^{3}$ assertion that the economic moment determines in the "last instance". Academically, Harvey's model implies that Cultural Theory (including discourse analysis) and Political Economy should inform each other. Fairclough and Graham (2002) argue for the relevance of 'critical discourse analysis' in revealing certain structuring principles of global capitalism (p. 187). They further assert that Marx was a "discourse analyst avant la lettre [before the term was invented]" (p. 225), as he analysed the interconnection of discourse and other social moments (p. 187), critically analysing the categories of political economy for what they exclude. My project focuses primarily on discourse, which in Harvey's model falls under the 'semiotic' moment (the production of meaning through signs), examining secondarily how this interacts with the dominant political-economy (Figure 3). This theoretical emphasis does not assume that discourse is the sole historically primary element, it simply happens to be the structural element my analysis begins from. Discourse is an element of ideological hegemony (Laclau and Mouffe, 1985/2001; Hall, 2006).

Hegemony first entered socialist discourse with the Russian slogan "proletarian hegemony in the democratic revolution" (Lih, 2006, p. 96-101; Laclau \& Mouffe, 1985, p. 50). This slogan meant that proletarian revolutionaries should monopolise "democratic" tasks such as universal suffrage and anticolonial liberation, rather than simply focusing on "economic" slogans (ibid). Italian Communist Antonio Gramsci famously developed this notion while imprisoned by Mussolini's regime, sketching ideas that now form the basis of hegemony theory. Gramsci's focus shifted from simply proletarian hegemony, to bourgeois hegemony, developing the notion into a more pervasive theory of class rule; cultural, political, and economic (Lih, 2006, 100-101). In this sense hegemony theory is a development of the classical Marxist theory of the state. Marx and Engels held that the economically ruling class in any regime must also be the politically ruling class (Engels, 1884). Gramsci argued that political rule, in order to last, requires a combination of coercion and consent, so in his formula:

state $=$ political society + civil society, that is, hegemony protected by the armor of coercion (Gramsci, 2011c, p. 75).

Gramsci contrasted this more expansive view of the state, incorporating the liberal ideal of the "ethical state" legitimated by popular consent, with the "gendarme or night-watchman [police officer] state", which would only guard private property (ibid). With bourgeois hegemony, civil society becomes an 
independent "state without a state" (ibid). Class rule is not just a matter of direct physical violence, but ideological hegemony. Although Gramsci was a Leninist, this focus on sophisticated 'democratic' hegemony is arguably more relevant to 'liberal democracies' (such as Aotearoa/New Zealand) than the experiences of the Russian revolution. It's also a less optimistic theory - as Lih (2006) observes, the term 'hegemony' in socialist theory develops from the confident notion that "we can use proletarian influence over other classes to achieve great aims" to the more pessimistic ${ }^{4}$ notion that "the influence of the bourgeoisie over even the proletariat keeps us from achieving very much" (p. 101). Gramscian theorist Ernesto Laclau (2005a) defines hegemony as "nothing more than the investment, in a partial object, of a fullness which will always evade us because it is purely mythical" (116). While I consider this a one-sided ${ }^{5}$ definition, it serves as a definition of the consensual component of hegemony - the investment of encompassing social meaning in a partial symbol, for example the idea that what's best for the national leader (a partial symbol) is best for everyone (the fullness of social existence). This research project asks how dominant parties seek consent. Gramsci describes the (discursive and political) superstructure as the skin of the (economic) structure, necessary to survival:

There is a necessary and vital connection between structure and superstructure, just as there is between the skin and the skeleton in the human body. It would be silly to say that a person stands erect on his [sic] skin rather than his skeleton, and yet this does does not mean that the skin is merely an appearance and an illusion - so much so that the condition of a flayed person is not very pleasant (Gramsci, 2011b, p. 157).

Cultural superstructure and economic structure are necessary to each other. Hall (2006) contends that while it may be reductive to say that ideas are determined in the "last instance" by economics (p. 28), determination by social structure in the "first instance" seems more appropriate (p. 44); we enter a social structure before we figure out how to respond. This is the basis of a "Marxism without guarantees," which recognises the "limits" of a social formation, but does not feign god-like predictive powers (p. 44).

4 This theoretical transformation occurred in Mussolini's jails, arguably similar to the growth of the Frankfurt School in the wake of the Third Reich (Jeffries, 2016), with fascist ideology posing a challenge to classical Marxist theories of social progress.

5 Laclau's insistence on elevating discourse over other historical moments leads him to theorise the consensual aspects of hegemony, while neglecting the material aspects; application of force, deprivation of resources. 
xvii

Without economically determined guarantees, the question of political agency is renewed (ibid). While cautioning that the structure/agency question may be a Gordian knot, Bieler and Morton promote a historicist approach (2001). Following Gramsci, historicism is not about establishing "universally valid" laws, but exploring action within "particular historical limits" (p. 22). Historicism emphasises time in the interaction of agents and structure - to put it simply, "Some structures are the consequences of actions by people in the past" (p. 9). Certain structures, like feudalism or capitalism, are deeply embedded and unlikely to change at a given point in time (p. 10). "Objective" simply means "universal subjective," or universally recognised by people - for example, the nation-state emerges as a "universal subjective" or "humanly objective" fact at this point in history (p. 22). The aim here is not to make an argument for or against the possibility of agency. In a distinction crucial for media analysis, Stuart Hall (2001) distinguishes between the moment of hegemonic "encoding," or production by dominant media, and "decoding," or reading by publics - the moment of decoding may be oppositional, negotiated or may reproduce dominant hegemony (p. 189-212). This project focuses on the moment of "encoding," the discursive attempt to ensure consent for the political-economic structure. At the macro-level, my analysis assumes that capitalism is a deeply embedded structure (p. 26), or to borrow a reworking from bell hooks, "white supremacist capitalist patriarchy" (1981). At a meso-level, the analysis assumes that neoliberalism is the prevailing world-system for organising capitalism (Cox 1987, p109; cited in Bieler \& Morton, 2007, p. 23), characterised by international flexibilisation, financialisation, and attacks on working-class organisation. While the recent global financial crisis has seen neoliberalism thrown somewhat into question internationally (Kelsey, 2005), this has largely meant injections of capital or small policy changes followed by a return to business-asusual (p. 244). In this international context, my analysis considers whether the articulations under scrutiny reveal unity in neoliberal discourse, or seek to constitute a 'people' that may fracture the prevailing discourse.

This project analyses hegemonic invocations of 'peoples' through Laclau's contradictory reading of populism. Laclau (2005a) defines populism not as a particular kind of movement or ideology, but rather as a "political logic" operating to various degrees throughout modern political discourse (p. 117). Conversely, Laclau draws a distinction between "populist" and "institutionalist" articulation: while 
Xviii

institutionalism limits discourse to forms that keep a community intact, populism polarises discourse between the 'people' and some opposing group (p. 81). Although it falls outside the scope of my current research project, the New Zealand National Party's award-winning (but electorally unsuccessful) 2005 General Election campaign provides a useful working example of populist political logic, both because of the stark rhetoric employed, and because leaked emails explicitly discuss the strategy (Hager, 2006). Don Brash had recently won party leadership. As campaign strategists worked to "repackage" Brash, his die-hard economic liberalism was increasingly seen as a liability, unpopular with voters (p. 61-62). Public Relations strategists advised simple and polarising discourse; "National stands for the BEST and Labour is destroying New Zealand" (p. 42). Even Roger Douglas, a key architect of neoliberalism, suggested ambiguously populist slogans: "Equal opportunity for all New Zealanders, not just the favoured few" (p. 45). This nationalist-populist rhetoric sat uncomfortably with the economic and social liberalism of the political actors employing it, but was seen as a more effective way of winning votes than openly articulating their political programme (p. 61-62). In a leaked private email to Brash, PR consultant Matthew Hooton explained the strategy:

I just hope you... don't think I am a populist. I'm not. I'm a right wing academic neocon [neoconservative] ultra. I just believe in winning too (Hager, 2006, p. 42-43).

While National's policy strategy was institutionalist in Laclau's terms (the maintenance and extension of neoliberalism and neoconservatism) their PR strategy in 2004-2005 was avowedly populist. To win, political strategists must constitute a 'people', defined by a "chain of equivalence" and a "frontier" of antagonism; an 'us' and a 'them' (Laclau 2005a, p. 81). In 2004, National's populist rhetoric sharpened - identifying a 'them' - with the infamous Orewa speech (Hager 2006, p. 79-96). National had lost votes to New Zealand First, which was exploiting fears about immigration (p. 83-84). Campaign strategists privately discussed the need for a "big populist issue," and settled on a "dog-whistle" concerning treaty settlements and "race-based funding," asserting that Māori were receiving special privileges (p. 83-88). National's polls doubled after this controversial speech, shooting from around 20 to around 45 percent (p. 79). The following year, this rhetorical strategy was boiled down to its essentials in the infamous "Iwi/Kiwi" billboard (p. 181-183), which identified National's constituency positively as "Kiwi" and Labour's negatively as "Iwi." This essentially dichotomises New Zealand with its indigenous people. This is one stark example ${ }^{6}$ of a more general logic - for Laclau (2005a), some logic of "equivalence" is 
xix

necessary for all political articulation (p. 18), and the "equivalential" chain always requires a "frontier" of difference or antagonism (pp. 93). Brash and his strategists invoked a cross-class ${ }^{7}$ chain of equivalence between Pākehā New Zealanders, defined by a frontier of antagonism with Māori. Following Laclau's arguments, my research project seeks to establish the chains of equivalence and frontiers of antagonism articulated in dominant electoral discourse - the competing and convergent articulations of 'us' and 'them'.

In addition to Laclau's distinction between 'institutionalist' and 'populist' discourses (which are interdependant rather than mutually independent), I suggest a further distinction, between left- and right-wing populism ${ }^{8}$ (Figure 4). Whereas right-wing populism names an antagonism between nation and elite, left-wing populism names antagonism between subaltern subjects and the elite. Left- and right- populism are divided by their distinct alliances, and more crucially by the promise of liberation/wholeness they each offer; the promise of an uncontaminated nation-state, or the promise of human emancipation from oppression and exploitation. These frameworks are not necessarily mutually exclusive. Parties may fluctuate between Institutionalism, Left-Wing and Right-wing Populism as tactics. Political tactics will be studied empirically, with an aim to ascertain dominant tendencies.

underline here that he does not use the term 'populism' pejoratively; his work is a defence of the category, albeit on the basis that it runs throughout all political articulation.

$7 \quad$ National's post-Orewa polling success was most pronounced among low-to-middle income men and the elderly.

8 Although this distinction between left-wing and right-wing populism represents a partial departure from Laclau as noted in Footnote 1, I find Laclau's abstracted framework useful for thinking through alliances in a refoundationalist fashion. My own adaptation of the framework is primarily developed as a critique of Anglosphere politics, where nationalism is arguably more regressive than in subaltern regions (Laclau's own sympathies lay with Latin American populist movements). 


\section{Three competing political frameworks}
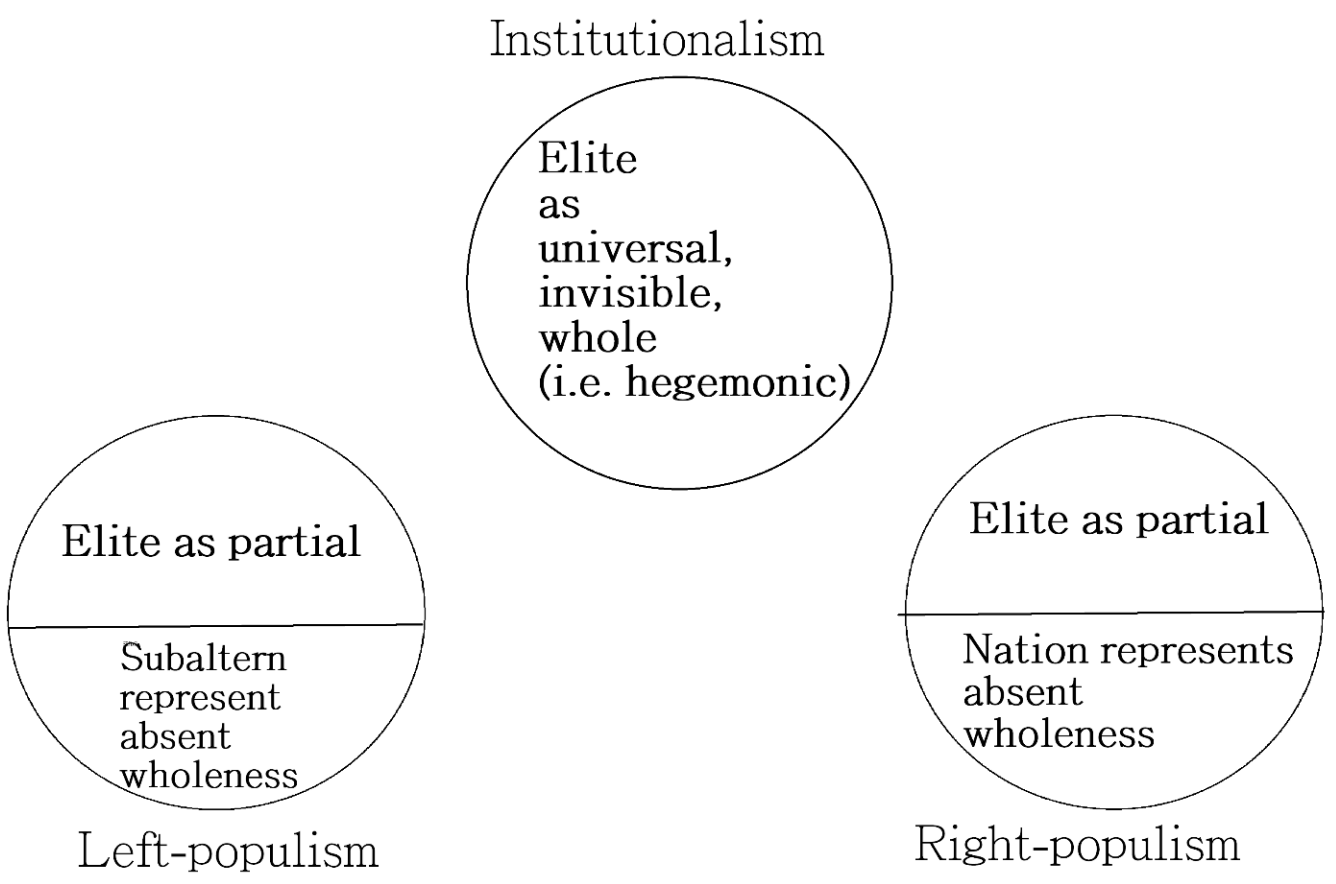

Figure 4

In close connection with Laclau's theorisation of the 'people', my analysis also employs the notion of contesting publics. This is a complication of Frankfurt School theorist Jurgen Habermas' work on the public sphere. Habermas understood the public sphere as a space, separate from the state, where private citizens communicate and deliberate (1964, p. 49). This notion largely originated in the bourgeois revolutions from the $18^{\text {th }}$ century onwards (p. 50-52). "Public authority" was associated with the emergence of modern capitalist nation-states (p. 51). Conversely, for Habermas, state authority is not a part of the public sphere (p. 49). Rather, the "liberal" or "bourgeois" public sphere requires that private citizens retain some freedom from state supervision; both in the cultural-political realm, and in the economic (p. 52-53). This notion of a deliberative public sphere, semi-autonomous from the state, is closely connected to the notion of civil society, which Gramsci ambivalently ${ }^{9}$ terms the "state without a state" (2011c, p. 75). In their 2001 preface to the $2^{\text {nd }}$ edition of Hegemony and Socialist Strategy, reflecting on the failure of Eurocommunism and the abandonment of class antagonism by much of the establishment 'Left,' Laclau and Mouffe critique Habermas' notion of a deliberative public sphere:

9 Perry Anderson contends that the "slippage" in Gramsci's use of terms like civil society, particularly whether it is a part of the state or opposed, is "neither accidental nor arbitrary" (1976). When I say that Gramsci's conception of civil society was ambivalent, I mean this in the strict sense; both positively and negatively valenced, internally contradictory, with different possible outcomes. 
"Unlike the Habermasians, we do not see [antagonism] as something that undermines the democratic project, but as its very condition of possibility" (Laclau \& Mouffe, 2001, p. xviii). Laclau \& Mouffe's critique of Habermas coincides with a certain Habermasian (or post-Habermasian) school, feminist scholar Nancy Fraser's formulation of "subaltern counterpublics" (1990). Fraser contends that "competing counterpublics" - nationalist movements, peasant uprisings, women's organisations, working-class organisations - disrupted the false unity of 'the public sphere' from the start, not from the late nineteenth and twentieth centuries as in Habermas' description (p. 61). Unlike Laclau and Mouffe, Fraser defends the deliberative public sphere as a normative ideal, although not one that has ever existed (p. 56-57, p. 78-79). However, crucially, she argues that pluralistic and contestatory forms are necessary for this ideal, rather than the notion of a single public unified by a false 'we' (p. 66-67). This certainly chimes with Laclau and Mouffe's emphasis on antagonism as necessary for radical democracy, and Laclau's critique of the false 'we' constructed by 'Institutionalism'. My project focuses neither on the public sphere, nor on subaltern counterpublics, but on the way dominant political actors seek to invoke 'publics.' This pluralised conception (from 'public' to 'publics) allows consideration of the various relationships between constituency and political programme, and whether political actors offer competing or convergent programmes.

While keeping Fraser's 'counterpublic' in mind as a necessary political step beyond the scope of this work (i.e. the emergence of subaltern agency), my analysis hinges rather on the public and nonpublic. This follows from Negt and Kluge's (1972) assertion, in critiquing Habermas' public sphere theory, that "actual rule operates -in full accord with the image of it evidently held by workers-in a nonpublic manner" (p. 289). Negt and Kluge use "nonpublic" to refer to productive relations of the factory (p. 39), a dictatorship excluded from the bourgeois sphere of democracy. My project uses 'nonpublic' more broadly to include all human elements excluded in order to produce a bourgeois-legitimated public honest, hard-working, participating, respectable citizens of a capitalist state. This follows from Foucault's (1980) suggestion of a central (and perpetually enforced) contradiction between "the proletarianised common people and the non-proletarianised common people" (p. 14). In other words, so long as they obey the law and do not disrupt production, workers can be considered legitimate bourgeois citizens - the nonpublic is often defined by criminality and active non-recognition, including prisoners, vagrants, and proletarians who resort to illegal methods. 
xxii

The prison system is a key site for the production of nonpublics. For Foucault (1977), the prisoner is the "common enemy" of society (p. 90). The prisoner is even cast as outside society (p. 110), or outside "the public' in our terms. In post-colonial societies, this division particularly serves as a racial caste system. Alexander contends that with the collapse of Jim Crow in the US, mass incarceration emerged as a new racial caste system (p. 2). Like previous caste systems, this sought to ensure poor white support for the ruling class - unlike previous caste systems, it required 'colorblind' rhetoric in the wake of the civil rights movement (ibid). Poor whites were won to Republicans through "law and order" rhetoric (p. 43-48). Now, while whites are just as likely to use and take illegal drugs according to self-reporting surveys, $90 \%$ of drug offenders sent to prison are African American (p. 98-99). Similar patterns apply in Aotearoa / New Zealand; alongside the move from 'assimilation' to 'biculturalism,' an expanding prison system houses a 50\% Māori population, compared with around 13\% of the general population (Smith, 2014a). Alongside directly controlling potentially rebellious populations such as ethnic minorities, the prison system must also have "lateral effects", regulating the behaviour of the 'lawful' public (Foucault, 1977, p. 95). The nonpublic defines the legitimate public by negation, and unlike Fraser's 'counterpublic', the nonpublic does not necessarily emerge as a self-organised constituency. The nonpublic is the scapegoat or nightmare used to regulate the public.

This project examines how the public is interpellated, rather than how actually existing publics respond. Interpellation refers to the way a subject is hailed, or called into being, by power - in Communist Louis Althusser's (1971) classic example, a person turning around when a police officer cries "Hey, you there!" (p. 174). Power names a subject, and the subject recognises herself. Michel Foucault famously outlined how systems of categorisation, rather than simply describing, naturalise a whole world-view (Brady and Schirato, 2010, p. 9). Feminist and poststructuralist theorist Judith Butler (1993) extends Foucault's theory by dealing with the psychic or psychological aspects of 'subjection', the making of a subject by power (Brady and Schirato, 2010, p. 22). Butler (1993) notes that Althusser's formulation leaves out the possibility of agency or disobedience, that the law might be refused or ruptured (cited in Brady \& Schirato, 2010, p. 22-23).This moment of resistance is coterminous in media analysis with Hall's (2001) notion of "oppositional decoding" (189-212). 
xxiii

However, the subjective member of the public, as thinking, feeling, fighting, despairing individual ${ }^{10}$, is absent from my analysis. The 'people' as historic agent is also absent. Rather, the project maps out bourgeois taxonomies of 'the public,' as subject, in electoral discourse. The subject is not so much a person, as a place in discourse where a person may enter:

"The subject" is sometimes bandied about as if it were interchangeable with "the person" or "the individual." The genealogy of the subject as a critical category, however, suggests that the subject, rather than be identified strictly with the individual, ought to be designated as a linguistic category, a place-holder, a structure in formation (Butler, 1997, p. 10).

It is crucial that the police officer, in Althusser's formulation, is an emissary of the state; subjects form in relation to power. An early work by Marx, On The Jewish Question (1884/2009), provides some grounding for this investigation of publics, as both singular and plural, with the singular 'we' defined in relation to the nation-state. Marx, who was himself Jewish, wrote this piece as a critique of theologian Bruno Bauer, who unlike Marx opposed civic rights for Jewish citizens (Cooke, 2013). While reproducing anti-semitic stereotypes universal to the writing of the time, Marx both welcomed bourgeois citizenship as a secularising step, and criticises its "egoistic" limitations:

The contradiction in which the religious man finds himself with the political man is the same contradiction in which the bourgeois finds himself with the citizen... The decomposition of man into Jew and citizen, Protestant and citizen, religious man and citizen, is neither a deception directed against citizenhood, nor is it a circumvention of political emancipation, it is political emancipation itself, the political method of emancipating oneself from religion... The sole bond holding [citizens] together is natural necessity, need and private interest, the preservation of their property and their egoistic selves (Marx, 1884/2009; emphasis mine).

Marx argues various collective subject-positions (Jew, Protestant) are brought together through the broader, secular subject-position of the 'citizen' (ibid). Further, Marx theorises the limits of bourgeois citizenship, limiting the economic 'Rights of Man' to essentially bourgeois rights, the right to own and exploit (ibid). In the wake of the bourgeois revolutions, the ideal citizen is the secular bourgeois citizen. The modern citizen, like the public, emerges with the bourgeois revolutions; a collective subjectposition, defined in relation to the capitalist state, with democratic rights and responsibilities. Following Marx's enquiry into the category of the 'bourgeois citizen', this research project asks; what are the limits

10 Except perhaps in the form of my own prejudices. 
xxiv

of the public? What is the class character of this formulation? What and who is silenced in naming the public? Who is the 'we'?

The analysis investigates whether political articulations invoke a transformative left counterpublic, or an 'enclosed' public reconcilable with capitalism. Jodi Dean (2016) reverses Althusser's claim that the individual is interpellated as a subject, so that instead power interpellates the subject as an individual (p. 74). This apparently slight reversal allows Dean to consider the subject as collective, as crowd, rather than individual (p. 88-89). Dean claims that the crowd is "the opportunity for politics" (p. 7). This is less Foucault's disciplined, juridical subject than the sovereign historical subject decentred by Foucault's account (1972, p. 199-211), in Žižek's ${ }^{11}$ terms the "spectre haunting Western academia" (1999, p. 1). Bourgeois power seeks to "enclose" the collective subject as an individual, ranked against other members of the crowd (Dean, 2016, p. 81). This projects seeks the 'enclosures' in discourse, the individual discursive particularities that avert the emergence of a collective communist subject - while also remaining open to the possibility that certain politicians or journalists may hail a more transformative leftist counterpublic.

11 Given the broader political thrust of this project, it may be worth noting here that I consider Žižek's recent comments on refugees in Europe an unacceptable capitulation to right-wing populism (see Kriss 2015a; Kriss 2015b). However, Žižek's earlier academic work is hard to avoid when it comes to the psychoanalytic dimension of ideology theory. 
XXV

\section{Specific Historical Background}

This project conceives of discourse as 'historically specific' (Korsch, 1938), i.e. best understood in social context, not purely through an empirical investigation of formal textual features. Research must therefore be grounded in a broader analysis of macro-level, historically embedded power structures. Late historian Tony Judt speculated in his memoir that the coming century was likely to see an increasingly violent policing of citizenship and the nation-state:

We are entering, I suspect, upon a time of troubles... Being "Danish" or "Italian," "American" or "European" won't just be an identity; it will be a rebuff and a reproof to those whom it excludes. The state, far from disappearing, may be about to come into its own: the privileges of citizenship, the protections of card-holding residency rights, will be wielded as political trumps. Intolerant demagogues in established democracies will demand "tests"—of knowledge, of language, of attitude - to determine whether desperate newcomers are deserving of British or Dutch or French “identity." They are already doing so (Judt, 2010, p. 15).

My analysis defines the nation as an "imagined community" (Anderson, 1982), a cross-class identification with the state. As an 'established democracy', Aotearoa/New Zealand is one testingground for the hypothesis of a narrowly policed notion of citizenship. Capitalism and parliamentary 'democracy' were established in Aotearoa/New Zealand through colonisation. The twentieth century saw both deep shifts and deep continuities with the pattern established by colonisation - most significantly for this analysis, urbanisation of the majority of Māori, and a shift towards neoliberalism in the last decades of the century. Donna Awatere (1984) contends that colonisation and capitalism have been facilitated partly through a 'white alliance' between Pākeha workers and capitalists (p. 34). This project therefore investigates what cross-sector coalitions are sought in mainstream political discourse, and whether these coalitions seek to disrupt or reproduce the prevailing political-economic system.

For David Harvey (2014), "accumulation by dispossession" is "the hallmark of what capital is really about" (p. 55). In Aotearoa/New Zealand, as in many other nations, the establishment of capital (and generalisation of wage-labour) first required the bloody dispossession of land from the indigenous people (Poata-Smith, 1997). Whereas the "first phase" of colonisation saw the partial exclusion of Māori from production (where Pākehā workers had the primary access to work, and Māori were forced into isolated rural areas), the second phase saw "proletarianisation" of Māori, particularly the rural-urban 
xxvi

migration of the post-war boom (p. 174-175). This fed into a second wave of militant resistance from the late 1960s, during which radical urban Māori combined forces both with other radical urban currents and with older rural Māori collectives (Hokowhitu, p. 360). After momentous struggles including the 1975 Māori Land March, the 1975 Treaty of Waitangi Act laid the basis for further reforms - although these arguably excluded many urban Māori (ibid). Meanwhile, the economic downturn of the 1970s infamously saw Dawn Raids on Pasifika "overstayers" (Anae, 2012), continuing the pattern whereby the European settler-state policed the boundaries of citizenship. After a period of social upheaval that continued into the 1980s, the Fourth Labour Government finally cemented the cultural-economic trajectory for the coming decades. While the government accepted progressive reforms in the field of cultural recognition; Homosexual Law Reform, the establishment of the Waitangi Tribunal, the establishment of the Ministry of Women's Affairs; it was also a key architect of introducing neoliberal restructuring to Aotearoa / New Zealand (Rudd and Roper, 1997). In feminist scholar Nancy Fraser's (2005) terms, gains in cultural "recognition" were traded for losses in economic "redistribution." While the Waitangi Tribunal has redistributed some funds, these are marginal in a period of declining real wages (Poata-Smith, 2004). Trends in inequality have been entrenched; while certain tribal authorities benefited economically from increasing legal recognition, "the vast majority of Māori families have borne the brunt of [neoliberal] economic restructuring" (p. 216). The general wealth-to-income ratio has expanded at an even greater rate than income disparity (Rashbrooke, 2015, p. 52). My analysis therefore explores this stratification of subjects under neoliberalism, between a recognised public and an unrecognised nonpublic (whether defined economically, ethnically, or in other terms).

Shifts in the dominant print media landscape have reflected broader shifts in political-economy, particularly the commodification of 'publics'. During nineteenth century colonisation, early regional newspapers were less nationally integrated than today (Hope, 1996, p. 13-14). Instead, they tended to be backed by regional businesses and politicians, with explicit editorial lines reflecting these interests; "Editorials also contained occasional outbursts against Māori, vagrants, unions and politicians from other provinces" (p. 14). In the late nineteenth and early-mid twentieth century, with the rising cost of mass printing, politicians gave way to companies, but these tended to still be politically conservative ( $p$. 15-17). From 1960, family companies gave way to more centralised monopoly capital (although protectionist policies ensured local ownership), facilitating a growth of critical journalism and political 
xxvii

commentary - although "mass media also provided government and business elites with the opportunity to manage news events" (p. 19-20). In the 1970s, media coverage of rising class, gender and ethnic liberation struggles undermined the "national imaginary," in both liberal and conservative variants (p. 21). Finally, the neoliberal assault from 1984 saw "convulsive takeover activity" and centralisation of media by transnational conglomerates (p. 21-23). Habermasian researcher Wayne Hope contended in 1996 that with the cross-partisan "neoliberal revolution" in Aotearoa / New Zealand, and the associated centralisation of media ownership by corporate conglomerates, public space has contracted and "a counter-hegemonic public sphere has yet to arrive"12 (p. 21-30). Under the current National government in Aotearoa / New Zealand, support for public media has further retreated (Thompson, 2011). As of 2016, the two major newspaper companies NZME and Fairfax are merging, meaning that both of the national newspapers will be owned by one company, and journalists' jobs are likely to be cut (Peacock, 2016). My analysis considers whether this increasingly corporatised media environment offers space for critical commentary, or reproduces dominant political discourse.

We live in a historical period typified by "democratic deficit," decreasing participation in mass and civic organisations (Beetham, 2002, p. 55-56; Grey and Sedgwick, 2012, p. 4). This pattern of contraction in public participation has played out in the electoral sphere. Electoral parties have centralised from 'mass' parties to 'electoral-professional' parties (Davis, 2010, p. 34-39). Edwards (2008) contends that this shift towards professionalisation has been facilitated by increased parliamentary funding, and decreased funding from business and trade unions, making parties less dependent on their membership (p. 4-11).

12 More recently, Hope (2012) has suggested that new communications technology, particularly the internet, may open up new space for public discourse (p. 28, 45). However, Cameron Slater's Whale Oil, the most popular NZ political blog, acts as a third-party "attack dog" for National Party insiders, according to leaked emails (Hager, 2014). While official channels ran a generically positive campaign under the slogan 'Building a Brighter Future', Slater carried out attacks on the party's political enemies (p. 28-36). Slater is also paid by tobbacco companies, and various other monied interests, to attack their critics under the pretense of non-partisan commentary (p. 7788). Given the prominence of Slater's blog in the new media environment, this may cast doubt over the potential for the internet to serve as a deliberative democratic 'public sphere.' Jodi Dean (2003) contends that rather than idealising the internet as a public sphere, or complaining that the medium falls short, the internet should be seen as a zero institution, a meta-frame that "enables myriad conflicting constituencies to understand themselves as part of the same global structure even as they disagree over what the architecture of this structure should entail" (p. 106). Unlike the democratic state, the internet favours "contestation" over "consensus" (p. 108). In any case, my research will centre 'official channels', the respectable faces of dominant political articulation, rather than the excesses of "attack politics" through third parties. 
Xxviii

At the same time, businesses are more likely to fund both major parties (p. 5). As Neil Davidson (2015) contends in an analysis of neoliberal political economy, if we concieve of the bourgeoisie as a "series of concentric circles," actual business owners sit at the centre, with more administrative roles radiating outwards. In this conception the state is largely the bureaucratic wing of capital, including politicians in ruling parties. My analysis will partially assume, and partially test, the notion of a constitutive cleavage between the majority of politicians and the majority of voters; politicians as representatives of bourgeois hegemony.

In 1992, Aotearoa / New Zealand held a referendum on adopting a Mixed-Member Proportional (MMP) system, which gives more space to smaller parties. Miller (2015) notes that the electorate's "plague on both your houses" attitude, after Labour and National governments had both implemented neoliberal reforms, led the electorate to support MMP (p. 87-88). In fact, voters generally did not understand the specifics of MMP (beyond proportionality), and were urged by both major parties to reject it, yet $85 \%$ of voters supported change to the electoral system, with $71 \%$ specifically preferring the MMP option (ibid). A 2011 referendum again affirmed MMP (p. 98-100), although only 25\% of CEOs supporting retaining it and 65\% supported scrapping it (NZ Herald, 2011). My analysis considers whether minor parties take advantage of MMP to promote oppositional causes, in particular whether they invoke a counterpublic that may disrupt the dominant neoliberal terms of rule.

Political Science researcher Jack Vowles notes that voter turnout in the 2011 General Election reached the lowest level since 1887, before women gained voting rights (p. 1). Turnout has generally decreased since 1946, with the exception of the period 1975-1984 (p. 2). Vowles suggests that this could be attributed to public perception that elections have predetermined results, weak policy differences on the left-right axis, limited community engagement by parties, and/or lack of support for civic education ( $p$. 22-24). Aeron Davis' survey Political Communication and Social Theory, while focused on the UK, outlines some patterns and frameworks for analysing political communication in this period. In line with other literature, Davis refers to a breakdown of party affiliations; "traditional links between parties and voters, based on socio-economic ties, have declined" (Davis, 2010, p. 35) This project contends that the situation is more partisan and class-divided than Davis' formulation; the capitulation of the political left, the defeat of the working class. Traditionally right-wing constituencies have not been hollowed out. 
xxix

Based on New Zealand General Election surveys in 2008 and 2011, non-voters are likely to be young; low-income; Māori, Pasifika or Asian; or some combination of the above (Statistics New Zealand, 2014a). Labourers are the least likely occupation to vote, followed by unemployed workers - at around $35-40 \%$ of non-voters (ibid). Non-voters are more likely to cite political disengagement (eg "it makes no difference which party is in government") than a perceived practical barrier (ibid; Figure 5). Very similar patterns are reported in the UK (Ailes, 2015; Hansard, 2015). Educational level is less of a predictor than income or ethnicity (ibid), perhaps casting doubt on civics education as a solution. Non-voters have been termed the 'missing million' (Williams, 2014). This project examines whether and how members of the 'missing million'; youth, low-income workers, and racially oppressed groups; are invoked (or disavowed) by parties and press.

The Civics and Media Project, a "non-partisan, cross-institutional initiative", suggests that "civic engagement in New Zealand is under threat" (Civics and Media Project, 2016). The project recommends the strengthening of civics education, public interest journalism, and resources and initiatives for adult New Zealanders (ibid). The emphasis on civics education implies an unstated normative dimension that New Zealand's civic institutions are sound, and simply need to be promoted more. High school teacher Bronwyn Houliston noted that Māori and Pasifika students were often politically engaged, yet alienated from dominant civic institutions (p. 7). If these institutions are structurally designed to serve dispossession, civics eduction may not foster engagement. Conversely, Senior Lecturer Carwyn Jones suggested an alternative solution: "Change the power structures from outside to create a new model of citizenship" (p. 11). Sandra Grey of the Tertiary Education Union suggested that "we don't need to reach a complete consensus, because if we do it will make life hard for those who live outside it" (p. 6). However, the conclusions of the project emphasised civics education (p. 2), limiting participation to existing institutional forms.

This project considers the institutional limits on political participation using the concept of Disciplined Democracy. Disciplined Democracy is a term that has been coined in relation to Burmese 'democracy', where disciplinary measures limit the ability to challenge the ruling party (Mon News, 2010). 'Disciplined Democracy' is an enforced form of political representation that actively limits the terms of participation (ibid). While Aotearoa/New Zealand may enjoy more political freedoms than Burma, my research 
$\mathrm{XXX}$

project uses the concept of 'disciplined democracy' to investigate the bounding of legitimate public participation by press and parties. The formulation emphasises Discipline over Democracy, using Discipline in Michel Foucault's (1977) sense: a method of power, an enforcement of norms (p. 184). Foucault suggests that disciplinary enforcement of the 'norm' may be "the new law of modern society" (ibid). My analysis considers whether press and parties limit normative discourses to existing institutional forms.

The analysis also considers whether political actors encourage more transformative engagement by counterpublics. For example, political actors hailing an alliance of working class Māori and Pākehā may challenge dominant invocations of 'the public'. Donna Awatere Huata (1984) contended in her influential work Māori Sovereignty that a 'restructuring of the white alliance' was ultimately needed, in our terms the formation of a new 'counterpublic' through alliance of Pākehā and Māori subalterns:

Set against our people has been the united strength of white people. The Māori now seeks to break that unity in the interests of justice for the Māori people... Gramsci's concept of hegemonic consciousness has relevance to Māori sovereignty. In hegemonic consciousness, a class puts its interests with other classes at a national level and establishes alliances with them. These alliances are necessary because changes cannot occur with the Māori on our own. White people have cut across class barriers to unite on the basis of white hegemony... To overcome this requires a restructuring of the white alliance (Awatere Huata, 1984, p. 34).

My analysis considers whether dominant coalitions, like the "white alliance", are maintained or disrupted in mainstream political discourse. 
xxxi

\section{Analytic Methodology}

This project studies how political parties and national press hailed 'the public' in the 2011 and 2014 Aotearoa / New Zealand General Elections. This is not intended as a sociological examination of actually existing publics, but an examination of how publics are hailed. A 'people' or a 'public' here is a place-holder in a wider ideological schema, a legitimation of a political programme. Research tests the thesis that dominant cross-partisan electoral discourses define the 'public' in terms of dual identification with productive work and capital, in opposition to named subaltern nonpublics.

My research begins with a content analysis of party press releases and mainstream election coverage. As a method, content analysis is primarily quantitative, and has been controversially described as "objective" (Macnamara 2005, p. 2). Political scientist and communications theorist Harold D. Lasswell (1948) influentially defined media content analysis with this formula, indicating the positive-empiricist framework that informed early media content analysis:

Who

Says What

In Which Channel

To Whom

With What Effect? (p. 37).

This arguably overstates the scope of content analysis, particularly its capacity to measure effects. Although this project analyses who (political parties) says what (naming publics) through which channel (press releases, national press coverage) to whom ('the public'), the effect of this cannot be comprehensively measured through an analysis of media texts. As Newbold et al contend, quantitative analysis of media data is not sufficient for understanding audience response:

There is no simple relationship between media texts and their impact, and it would be too simplistic to base decisions in this regard on mere figures obtained from a statistical content analysis (Newbold et al 2002, p. 80).

As previously mentioned, this project is more focused on the moment of hegemonic 'encoding' than audience 'decoding' (Hall, 2001, p. 189-212). However, some comparisons between electoral discourse and public behaviour are discussed - through polls, final vote, and surveys of non-voters, as an indicative rather than conclusive measure. A fuller analysis of audience response requires a more 
xxxii

participatory approach, which is outside the scope of this project.

Media content analysis seeks a 'scientific' approach to media analysis, seeking to avoid confirmation bias. Influential researcher Kimberley Neuendorf (2002) defines content analysis as follows:

Content analysis is a summarizing, quantitative analysis of messages that relies on the scientific method ... and is not limited as to the types of variables that may be measured or the context in which the messages are created or presented (cited in Macnamara, 2005, p. 2).

Although not claiming my overall project is 'objective', I endorse Neuendorf's definition of content analysis as quantitative and 'scientific'. Researchers can test quantitative hypotheses about content, and the results could be reproduced by someone with a different ideological bias. For Neuendorf (2002), content analysis is separate methodologically from qualitative analysis (p. 5-7). My own prejudices as a young, Pākehā, male-assigned, queer, communist student may affect qualitative interpretation of data, but should not affect the quantitative results of a content analysis. A National Party supporter could also prove (or concede) that a certain number of terms are used a certain number of times, although our political interpretation of these findings may differ. The quantitative dimension helps to ground this political analysis in a clear 'map' of the discursive terrain, patterns in political articulation that may not be pre-conceived within an ideological lens.

The content consists of two samples; press releases by parliamentary parties (National Party, Labour Party, Green Party, New Zealand First, Māori Party, MANA, Internet Party, ACT, United Future), and electoral coverage in major newspapers (NZ Herald, Dominion Post). This quantitative survey is restricted to the last two weeks of the 2011 and 2014 General Elections, both to study official discourses of the 'public' in a period of democratic deficit, and to ensure available comparable data. Newspaper data is drawn first from the microfilm of newspapers (to get an impression of layout, which may be relevant to assessing political priorities), and then from online databases (making it easier to compare large quantities of data). All but one ${ }^{13}$ of the parliamentary parties under analysis have press

13 The Internet Party, an apparently short-term formation that ran on a joint ticket with MANA in 2014 General Elections, does not have press releases on their website. The Internet Party is also the only party in this survey not to have any seats in parliament. However, as they ran a joint campaign with MANA (which had a single seat) they are a necessary part of this electoral survey; their press releases are available on Scoop and other 
Xxxiii

releases on their websites, however the extent of these archives is inconsistent. Where archives are lacking, I contact the parties in question, and finally consult Scoop (which reprints all press releases unedited). This survey covers a total of 514 political party press releases (310 from 2011, 204 from 2014), and (510 from 2011; 219 from 2014). I first compile the content into text documents, then quantify manually using spreadsheets. The focus on parliamentary party press releases and national newspapers, across two consecutive elections, both ensures that the content will be technically comparable (many parliamentary parties only began placing press releases on their websites very recently), and will capture dominant political discourse. As of $2014,78 \%$ of people in Aotearoa/New Zealand access newspapers both online and in print, and $52 \%$ of people still read newspapers on a daily basis (NZOA, 2014; cited in CBB, 2016). Nzherald.co.nz and Stuff.co.nz (website of the Dominion Post) are among the top 10 ranked websites in New Zealand in terms of hits (Alexa, 2014). Therefore while this analysis cannot capture subjective audience reception, it can capture dominant discourse.

I prepare an initial list of nouns, then after manually checking the initial list of nouns against the content, expand the coding schedule to incorporate unanticipated terms. However, I keep terms that do not show up, as their absence is potentially significant in its own right. For example, I add the category 'partnership' on noticing that the National Party often uses this term. Conversely, I keep a full list of terms for gender and sexual diversity in the coding schedule, although these terms are rare to the point of nonexistence, as this absence itself merits commentary (particularly in terms of 'nonpublics'). Once satisfactorily reworked, the coding schedule is consistently applied across all content. My coding schedule includes 14 categories (Ethnic, Economic, Gendered...) and 213 individual nouns (Appendix). These nouns are not meant to correspond to objective sociological categories, but rather to dominant political invocation of 'publics'. The terms 'taxpayer' and 'worker' could in many cases refer to the same person, yet the ideological inflections of these terms are distinct. Again, this project analyses signifiers of the public, not the signified public. This project is not investigating subaltern experiences of race and gender for example, but the way subjects are racialised and gendered. While quantifying nouns, I make brief notes for future reference; e.g.'youth' is often used in close connection with 'crime'. I also compare party press releases with mainstream press coverage, to identify which party-political formulations find mass circulation.

secondary websites. 
xxxiv

There are two main visual methods used to present the quantitative data: pie charts to compare isolated key terms, and tables to present larger samples of data. Pie charts present the polarities in the data: comparisons between terms like Māori and Pākehā, Men and Women, or Workers and Capitalists. The comparison seeks their relative rather than absolute popularity - e.g. which of the terms 'Men' and 'Women' are used more often, rather than how often each term is used overall. These binary comparisons may help to establish the frontiers of political articulation (Laclau, 2005a), the 'us and them', or perhaps the coalitions between different sectors. Whereas I use pie charts to illustrate comparative percentages, I used tables to present raw numbers. This helps in comparing a range of sources, a range of terms, and including the absences in discourse (nouns never used).

From this content analysis, the project proceeds to a critical discourse analysis. Articles are selected which in some way typify the data; if the terms 'we' and 'workers' are often used together by a party, I select a party press release where this happens particularly often, to examine the political function of this formulation. Again, the quantitative data is drawn solely from a strict time period (last two weeks of 2011/2014 General Elections) to ensure comparable data. However, qualitative examples are drawn from other points in recent NZ parliamentary history, to provide context and comparisons. This critical discourse analysis centres on political demands, a central category in the political constitution of a people (Laclau, 2005a, p. 74-75). Demands are analysed in part through Nancy Fraser's (2005) framework of (cultural) recognition, (economic) redistribution, and (political) representation. For the purposes of this analysis; representation includes 'misrepresentation,' established civic forms of delegated authority which may fall short of democratic ideals (the two-party system, for example); redistribution includes all forms of complex wealth distribution, including neoliberal upward redistribution or 'maldistribution'; and recognition includes 'misrecognition,' as in semiotic violence. The reason for this conflation is simple; this project focuses on dominant institutions (which may incorporate popular demands), rather than on the liberation movements Fraser centres. Take the slogan "end race-based funding for Maori”, used by Don Brash in the lead-up to the 2005 election. This slogan demands an end to a form of cultural recognition for Māori. The slogan further implies that the existing political regime does not adequately represent Pakeha, the legitimate public. Finally, the demand to end state funding concerns economic redistribution (or perhaps an end to redistribution). Conversely, the slogan "Honour 
the Treaty [of Waitangi]". In this slogan, Māori are recognised as a legitimate public. The slogan also implies that iwi leaders, who first signed the Treaty, legitimately represent Māori politically. Finally, the slogan implies that the Treaty has not been honoured, as Māori have been dispossessed, and therefore makes a demand for redistribution of economic wealth. Understanding these slogans requires an application of political context, demanding a qualitative analysis to understand the results of the content analysis.

An isolated democratic demand, when met, can become inscribed into the prevailing regime (Laclau, 2005a, p. 77). By contrast, a plurality of demands that constitute a 'dichotomic frontier' in society are considered popular demands (p. 73-86). According to Laclau, the difference between an 'institutionalist' and a 'populist' framework lies in the difference between a discourse that assumes the wholeness of a community and one which "divides society into two camps" (p. 81). My analysis therefore considers whether political demands seek to polarise or unite constituencies. The analysis further considers whether these constitutions of political (dis)unity can be easily inscribed into the existing totality, or whether they call the totality into question. In particular, the project considers how competing political programmes negotiate the terms of neoliberalism (at a meso level) and white-supremacist capitalist patriarchy (at a macro-level): whether and how these structures are acknowledged, reinforced, questioned, challenged. Kelsey (2015) suggests that at an international level, the "neoliberal consensus" is beginning to fracture, although New Zealand remains largely "cocooned" (p. 175). Further, any departure from neoliberalism must be wholesale, as it is a "robust regime" that cannot be challenged in piecemeal fashion (p. 125). My analysis considers whether official political discourse shows any signs of fracture in the "neoliberal consensus," and if so, whether alternative political programmes are suggested. This analysis of programme considers how competing political actors appropriate 'floating signifiers', popular terms whose meaning is 'indeterminate' (p. 131), which competing political projects can appropriate in service of their programme (p. 131-138). The project asks whether competing political articulations simply reproduce the terms of the broader global terrain, or whether they hail a 'people' (or 'counterpublic') that may disrupt this common frontier. The analysis focuses on national print media, as a locus of dominant-hegemonic political articulation. This is not to say that the content is only 'traditional media' - many press releases are now sent out exclusively online - but that it concerns official political discourse rather than the unofficial and unregulated. 
I have outlined a number of a priori frameworks. This may give the impression that this project's reasoning is circular, begging the question: what data would trouble my hypothesis? In 2008, a small outfit called the Workers Party ${ }^{14}$ ran in national elections with the slogan "Workers should be running the country" (Workers Party, 2008). If a major parliamentary party made such a call for proletarian power, this would undermine the thesis that dominant cross-partisan electoral discourses defined the 'public' in terms of dual identification with productive work and capital, in opposition to named subaltern nonpublics. To pose the case less starkly, if a major political actor named polarisation between rich and poor, with an appropriate programme to address this polarisation (whether reformist or revolutionary), this could also prove a left-wing exception. By contrast, a polarisation between capitalist nation-state ${ }^{15}$ and elite may interrupt neoliberal institutional discourse, but counts in my taxonomy as 'right-wing populism' (Figure 4). My first chapter will consider the dominant political discourse of the two major parties (National and Labour).

14 I was a member of the Workers Party, and remain a member of the Workers Party's successor organisation Fightback.

15 By nation-state I refer here to colonial New Zealand. Conversely I do not intend to damn the politics of Māori Sovereignty, a stateless 'nationalism' that may serve to disrupt white-supremacist capitalist patriarchy. This possibility will be investigated in particular relation to the MANA Movement. 
XXXvii

\section{Categories for not voting}

2008 and 2011 general elections

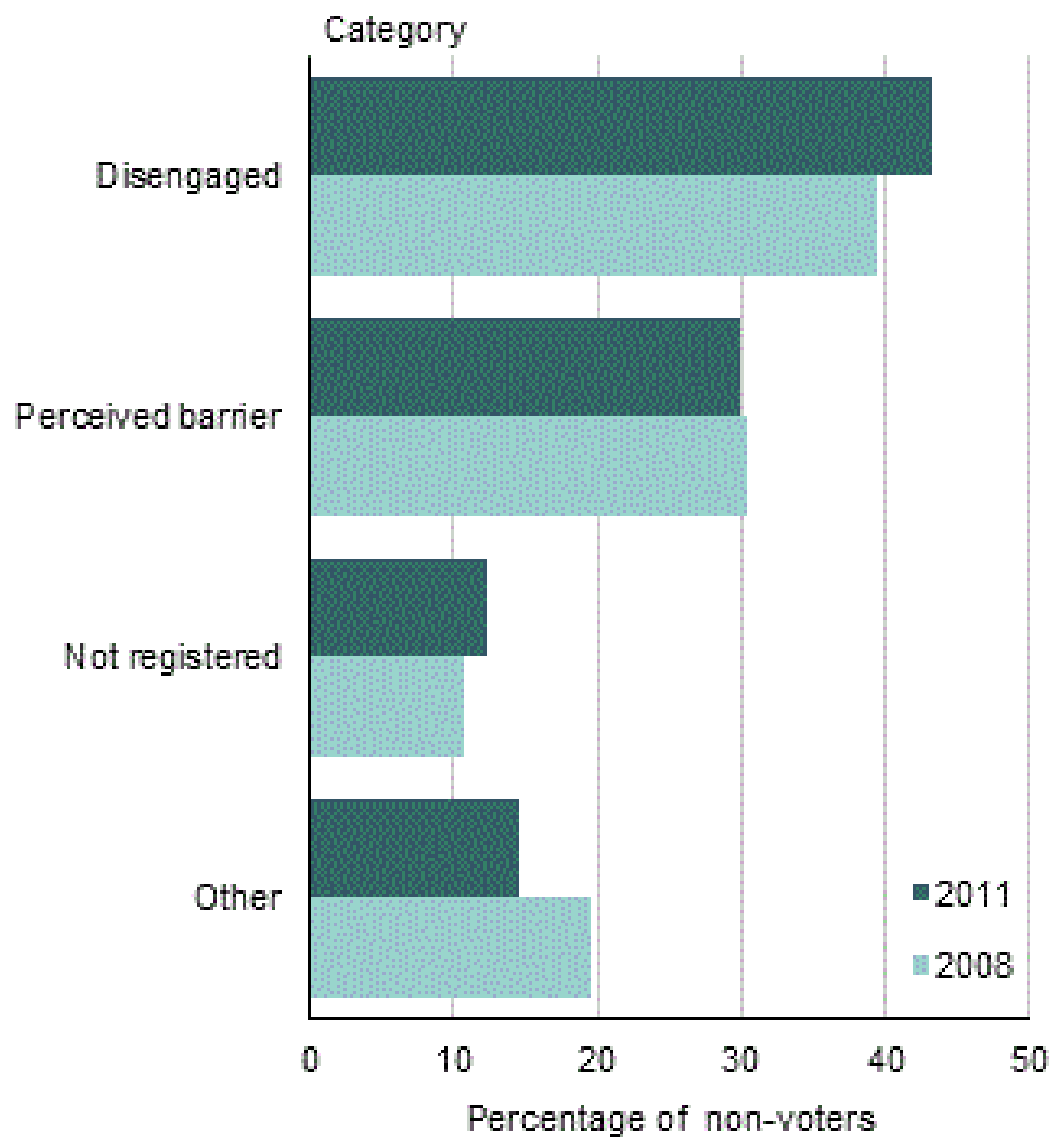

Source: Statistics New Zealand

Figure 5 



\section{Chapter 1: Institutionalism and Right-Wing Populism}

This chapter characterises the discourse of the two major parties, National and Labour, particularly in terms of their relationships to nationalism. The chapter begins with the findings of my content analysis concerning pronoun usage (Section I). Ruling party National is the most likely party to use first-person collective pronouns - 'we' or 'our' - rather than third and second person pronouns (Figure 6). This invites the question of who 'we' are politically. In absolute terms, the most commonly invoked public across parties is 'New Zealander'. I therefore suggest that the major party 'we' stands for the party representing the nation, or the part representing the whole. In considering the 'nation' as a common field of political discourse, my analysis defines the 'nation' as an "imagined community" (Anderson, 1982), a discursive formation inviting cross-class identification with the bourgeois state. My critical discourse analysis seeks to identify how the competing parties appropriate the 'floating signifier' of the nation, a term that can be appropriated by competing political actors (Laclau, 2005a, p. 131-138). This analysis also examines the converse terms for 'New Zealander', which may reveal aspects of competing programmes - the ruling National Party is the most likely party to use the term 'international', using this term 30 times in the data surveyed, while the opposition Labour Party is most likely to use the term 'foreign(er)', using the term 35 times (Figure 8). My critical discourse analysis considers these distinct terms ('foreign' and 'international') through Laclau's distinction between 'institutionalism' and 'populism' (1985, 2005a, 2005b). For Laclau, institutionalism naturalises differences (such as class, race, gender) as positive facts that can be administratively addressed by the regime without a need for social antagonism (2005a, p. 81; 2005b, p. 48), whereas populism polarises differences (2005a, p. 81). The analysis will demonstrate that National's 'institutionalist' terminology represents a form of bourgeois internationalism, whereby the interests of international business are identified with the interests of New Zealand business, and therefore 'the public' as a whole. Conversely, Labour's references to 'foreign' threats represent a kind of Right-Wing Populist opposition, failing to distinguish between migrant labour and international capital.

This analysis considers how each party constitutes the national 'we', before expanding on the comparison of 'international' and 'foreign' terminology. Critical discourse analysis begins with the National Party (Section II). In addition to the cross-partisan representative 'we', close analysis of press releases will demonstrate that the National Party tends to use a confident executive 'we', singularly and 
competently mediating between social interests. In a neoliberal inflection of institutionalist discourse, the National Party 'we' offers a managerial voice, which elevates management principles to a general ideology (Klikauer, 2013), in this case implying that managing a nation-state is akin to managing a business. As Laclau offers Disraeli's One Nation Conservatism as an example of 'institutionalism', I also compare National Party discourse with One Nation Conservatism. One Nation Conservatism emphasises the nation as a site of reconciliation between competing interests, also a feature of National Party discourse. However, National Party discourse emphasises social mobility over directly addressing poverty, a departure from classical One Nation Conservatism. The National Party's institutional-managerial discourse is also bourgeois internationalist, promoting integration with neoliberal international institutions - particularly promoting international trade agreements. For the National Party, participation in the international neoliberal regime is best for New Zealand business, and therefore all New Zealanders. The National Party's institutional discourse invokes a national public, yet one whose interests are equated with those of international capital, erasing social contradiction through institutional wholeness.

Having examined the discourse of the ruling party, I move on to a critical discourse analysis of the main Opposition party, Labour (Section III). The findings suggest that Right-Wing Populism is Labour's dominant discourse. Labour's 'we' has a stronger 'they', a passionate site of identification in a polarised discourse. Labour often refers negatively to 'foreign' actors. This move displaces economic anxieties onto racialised 'foreign' nonpublics, i.e. scapegoating. As a demonstrative example, my critical discourse analysis examines a recent controversy over Labour's commentary on the housing crisis. Growing tensions in the housing market demand political response; in Marxist terms. the contradiction between use value and exchange value (Harvey, 2014), whereby working class access to houses is undermined by profitable fluctuations in price. Neither of the major parties identifies class contradiction as a driving factor. National denies the existence of a housing crisis. Conversely, Labour focuses only on the 'Chinese surnames' of buyers (Gibson, 2015). This failure to distinguish between economic migrants and international capital results in controversy over racism (ibid). Recent migrants are highly unlikely to vote (Statistics New Zealand, 2014a), a fact which may be associated with the scapegoating of 'foreigners' as a nonpublic. Labour's Right-Wing Populism seeks to rouse discontent without challenging the bourgeoisie at home. The two parties therefore employ distinct bourgeois invocations of 
a national public. Having characterised the dominant invocations of 'publics' across the two major parties, the following chapter proceeds to consider how dominant discourses 'recognise' subaltern identity. 


\section{Party pronouns 2011-2014 \\ (rank: 'We'/'Our' most to least common)}

1st: National Party

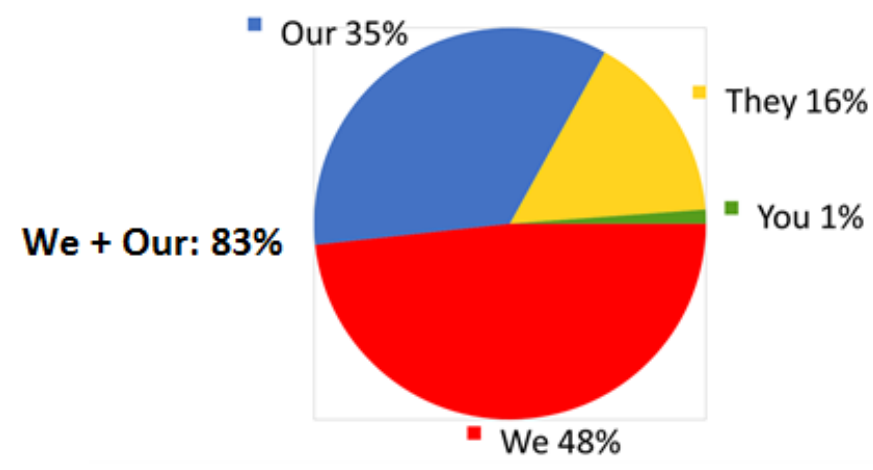

3rd: Green Party

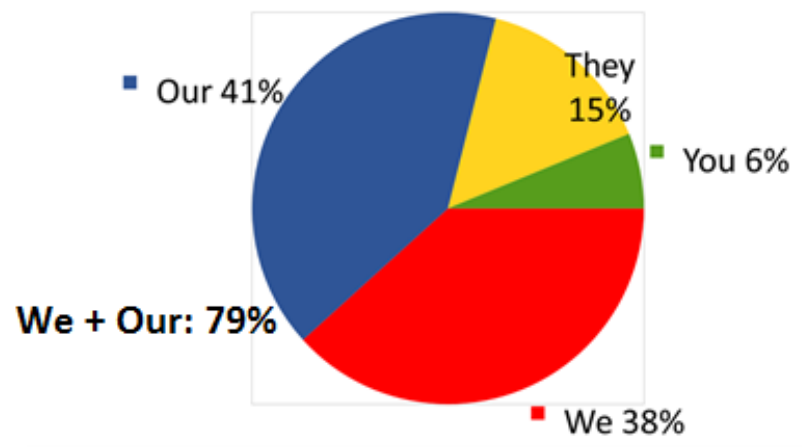

2nd: Maori Party

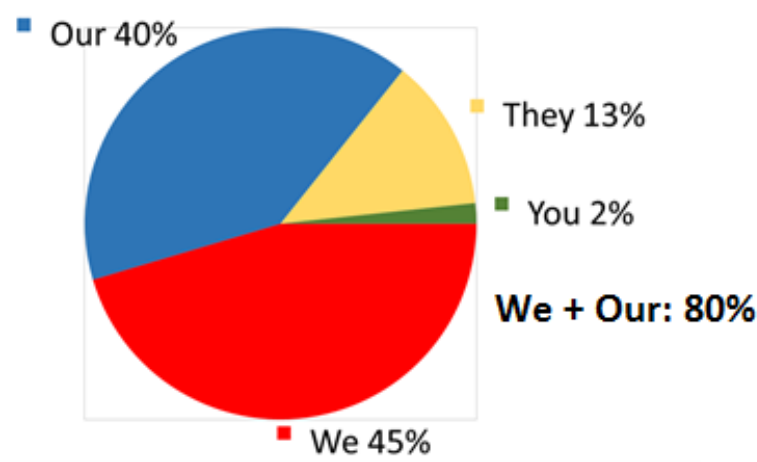

4th: United Future

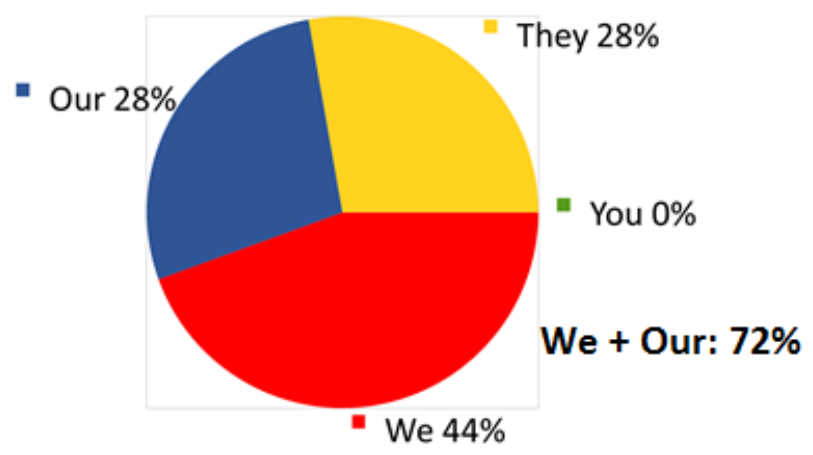

Figure 6 


\section{Party pronouns 2011-2014 cont'}

(rank: 'We'/'Our' most to least common)

5th: Labour Party

They $31 \%$

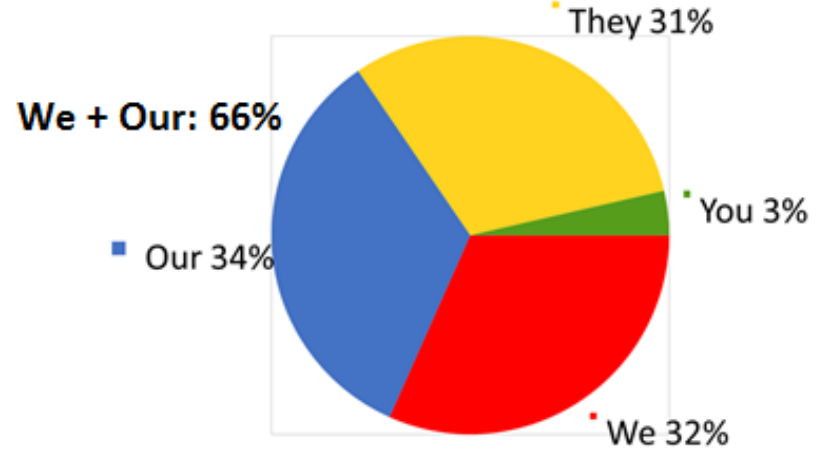

7th: New Zealand First

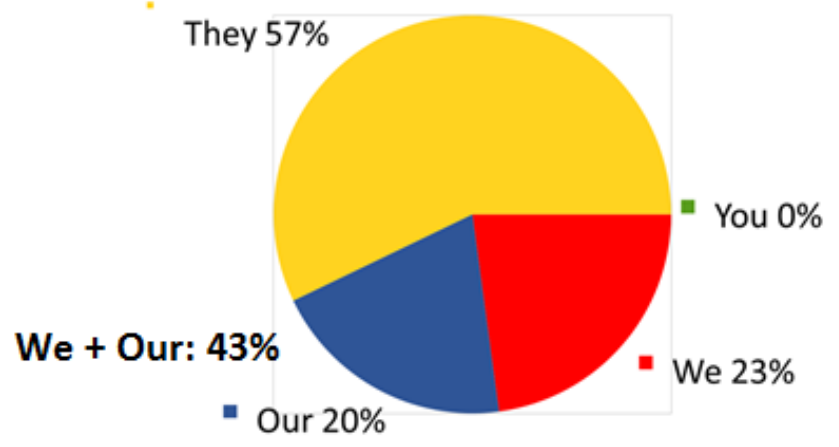

6th: Internet-MANA

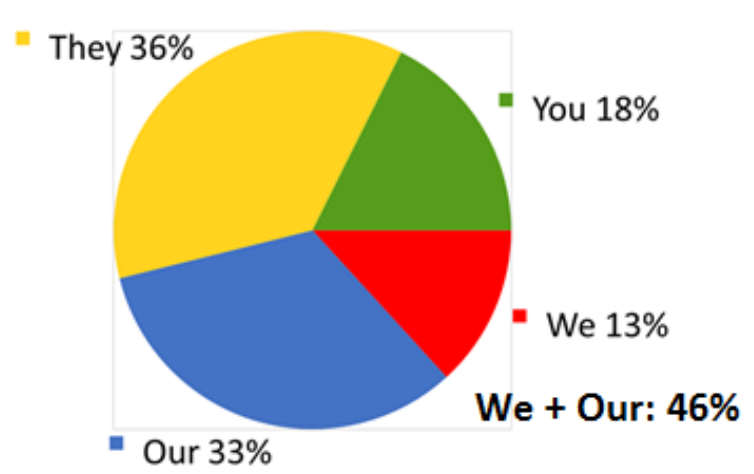

8th: ACT

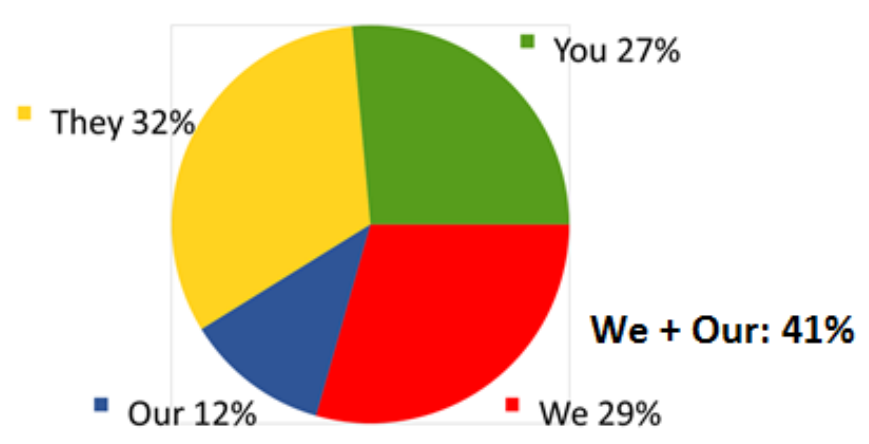

Figure 6 


\section{Who are 'we'?}

This chapter focuses on the two major parties: the ruling National Party and Opposition Labour Party. The analysis first surveys pronouns, which tend to imply identity; a collective pronoun groups people together, a singular pronoun individuates, and can offer clues as to gender identity. I focus on how the pronouns group parties with or apart from others; the question of 'us' and 'them'.

National strongly prefers first-person collective pronouns ('we', 'our') to third person ('they') or second person pronouns ('you'). This is the strongest preference of any party, with National's first-person collective pronouns at a combined $83 \%$ of their pronouns(Figure 6). The main Opposition party, Labour, sits around the middle of the spectrum, with combined first-person collective pronouns at $66 \%$, and 'they' used about twice as often as the National Party (ibid). Minor right-wing populist party New Zealand First has the strongest 'they', at $57 \%$ of pronouns surveyed (Figure 6 ). The ruling party's strong preference for first-person collective pronouns ('we' and 'our') invites the question of who the 'we' is in dominant discourse.

Across all categories - National/Ethnic, Economic, Gendered et al - parties were most likely to hail 'New Zealanders' as their principle public. 'New Zealand' is the public that parties claim to represent, with the exception of the MANA and Māori Parties who each name 'Māori' as their main constituency. MANA and Māori could be considered exceptions in their emphasis on an ethnic basis for constituency, however this would ignore the way Pakeha identity may be concealed by the dominant category New Zealander (to be discussed further in Chapter 2). I argue therefore that the dominant cross-partisan 'we' stands discursively for the party representing the nation. Parties insist that 'we' best understand the concerns of ordinary New Zealanders:

Labour MP Grant Robertson: "Like most New Zealanders, we know tough decisions need to be made to get our country back onto a sustainable path" (Robertson, 2011c; emphasis mine).

National MP Craig Foss: "Our across-the-board tax cuts also mean there's more money in the pockets of older New Zealanders" (Foss, 2011; emphasis mine).

Although these quotes cover distinct policy areas and parties - Labour on environmentalism and National on taxation, respectively - they share a common discourse; the first-person collective 
pronoun invites a representative link between the party and the nation. The party understands what is best for the nation, the concerns of ordinary citizens, and acts accordingly.

In both National and Labour articulations, the national-parliamentary form of representation is the primary and ideal form - tautologically, the New Zealand public is best represented by the New Zealand state. Bourgeois parliamentary democracy has a "zero value" in Levi-Strauss' (1963) sense, assumed as the common basis for discourse, usually unstated. It therefore provides a cross-partisan basis for the 'we'. Each party places a claim on this common field of representation. This common discourse helps construct an "imagined community" (Anderson, 1982), a national constituency bringing together individuals or communities that could be constituted on different, competing grounds -e.g. as a working-class constituency, an indigenous constituency, a gendered constituency. Because this common discourse invites working-class identification with the national ruling class, my analysis considers the bourgeois nation (New Zealand) as a common ground of discourse.

This chapter hinges on who 'we' are politically, or what 'we' major political players invoke. The critical discourse analysis will focus on press releases by the two major parties, and proceed from their specific uses of pronouns to a broader consideration of how they constitute the national public. While the 'we' of major political players overlaps substantially - with the bourgeois nation as the primary glue - specific parties articulate more specific discursive relations between public and party. The analysis will consider these distinctions in terms of Institutionalism and Populism, which for Laclau (2005a) are the two key poles of political articulation. 


\section{National's managerial 'we'}

This chapter has outlined the notion that the first-person collective pronoun in party press releases implies a representative link between party and nation. However, this demands further expansion and specification through critical discourse analysis. The National Party's use of the 'we' pronoun has some distinct inflections, implying a competent mediator between competing interests. My critical discourse analysis will consider this 'we' in terms of Laclau's formulation of 'institutionalism' (1985, 2005a, 2005b). As Laclau offers Disraeli's One Nation Conservatism as a key example of 'institutionalism', I compare National Party discourse with the discourse of One Nation Conservatism, a classic discourse of the English Tories. One Nation Conservatism emphasises the nation as a site of reconciliation between competing interests. In a neoliberal context, National Party discourse tends to emphasise social mobility over directly addressing poverty, a departure from classical One Nation Conservatism. I argue that National's inflection of Conservative institutional discourse implies managerialism, the elevation of private sector management principles to a general ideology (Klikauer, 2013), in this case the assumption that the role of government is to promote private sector expertise. The National Party's institutional discourse is also bourgeois internationalist, promoting integration with neoliberal international institutions. Statements tend to equate the interests of capital, the state, and the public, as interdependant interests that must be reconciled through correct administration. Prime Minister John Key typifies the official National Party discourse in his relatively 'apolitical' media engagement (often appearing on entertainment media rather than current affairs), implying an absence of social or political conflict. The National Party's institutional discourse invokes a national public, erasing social contradiction.

Laclau mentions Disraeli's 'One Nation' as an example of an Institutionalist totality (1985, p130; 2005a; p. 81). Before proceeding to a critical discourse analysis of National Party 'institutionaism', I will outline features of One Nation Conservatism to contextualise this analysis. The intention here is not to claim that Key or the National Party are traditional 'One Nation Conservatives', but rather to consider the ways in which Disraeli's classic articulation of Conservativism can help to explain Institutionalist discourse in general. One Nation Conservatism traditionally holds that the wealthy have a "duty of care" to the lower orders, a form of noblesse oblige (Dorey, 2010, p. 49). Benjamin Disraeli, the original theorist of One Nation Conservatism, expressed concern about economic inequality forming 'Two 
Nations' (p. 52-53). Crucially, while some degree of inequality is inevitable, conflicts can be reconciled within the common ground of the 'nation' (p. 51-57). For Laclau (1985), the institutionalist logic of One Nation Conservatism found a later expression in the Welfare State (p. 130). Differentiality must be reconciled, and cannot be allowed to threaten the prevailing system (Laclau, 2005a, p. 81). Notably, One Nation Conservatism has been described as a "pragmatic" project, driven partly by the need to court working class publics, as the nineteenth century saw the extension of the franchise to male workers (Dorey, 2010, p. 55-57). This is where One Nation Conservatism, and perhaps actuallyexisting-Institutional discourses in general, depart from the classical liberal "gendarme or nightwatchman [police officer] state," which would only protect property; as in Gramsci's (2011c) account, the "ethical state" forms to achieve popular consent (p. 75). In examining post-Thatcher conservative discourse, Dorey (2010) expresses concern that "regardless of the Conservative modernisers' genuflections towards One Nation Conservatism, Britain will remain two, increasingly divergent, nations" (p. 182) In line with Laclau \& Mouffe (2001), I assume the "ineradicability of antagonism" (p. xvii), not in the Conservative sense that inequality is natural, but in the sense that antagonism is the "condition of possibility for democratic politics" (p. xviii). Rather than seeking reconciliation, I assume that the economic interests of labour and capital are irreconcilable. My emphasis is therefore on examining institutional conservatism as an impossible discourse that seeks to foreclose antagonism, rather than the likelihood of conservatism actually erasing economic inequality.

The National Party often implies an 'ethical state' (using Gramsci's term), an aspect of One Nation Conservatism (Dorey, 2010). Press releases outline a number of areas where the ruling party doesn't simply preserve private property, but acts in the national interest. In some cases, the National Party employs a 'we' that blurs the line between party and nation:

We are a nation with some of the most spectacular and unique coastlines in the world and we need to recognise the importance and value of these marine habitats (Smith, 2014b).

Here environmental conservation is understood as a national priority, uniting an entire "imagined community" with a common 'we' (Anderson, 1982). This national discourse is relatively cross-partisan, also used by the Labour Party and Opposition parties (see Section III). However, I suggest that where the National Party offers a more party-specific discourse, distinct from the other parties, 'we' indicates an institutional differentiation; 'we' as opposed to 'you', rulers as opposed to ruled. The National Party's 
executive discourse implies managerialism, the elevation of private sector management principles to a generalised ideology:

[M]anagerialism's perilous central doctrine is that differences between a university and a car company [or even a government] are less important than their similarities and that the performance of all organizations can be optimized by the application of generic management skills and knowledge (Klikauer, 2013, p. 5).

The National Party accepts as 'common sense' the notions that private sector actors promote efficiency, that the role of government is to pave the way for business, under the assumption that business will ultimately serve national interests. A National Party release on broadband policy explains that the party has established private sector infrastructure, promoted competition, and thereby served the general interest:

We have established four public-private partnerships for the Ultra-Fast Broadband initiative and one for the Rural Broadband Initiative...

We have also improved regulations to encourage competition...

We have the framework and the partnerships in place, but Labour are saying they would unpick the whole thing (Joyce, 2011; emphasis mine).

This 'we' is exclusive, distinct, individual, referring to the party as distinct from other actors. Yet the 'we' is also a mediator, negotiating with business for the good of the community as a whole. Labour is portrayed as pursuing special interests that undermine the general interest, as in One Nation Conservatism (Dorey, 2010, p. 51). At times National Party releases explicitly refer to balancing competing interests:

We also can't ignore the major economic opportunity that continuing global oil demand stands to provide New Zealand...

We will remain focused on energy efficiency, renewable energy, the exploration of our natural resources and the pricing of carbon as we manage our environmental responsibilities and realise our economic opportunities (Parata, 2011a).

The party is a national actor, over and above the various sectional interests. The genuflection toward environmental responsibilities implies reconciliation, the mediation of competing interests for the common good; the demands of oil barons and environmentalists somehow reconciled. The notion of reconciling competing interests through the 'nation' sits at the core of One Nation Conservatism (Dorey, 
2010 , p. 52). As with Laclau's (2005a) account of institutionalism, the limits of articulation lie at the limits of the community, rather than polarising the community in a populist fashion.

The National Party 'we' is a managerial voice, offering generalised coordination, ensuring business growth, making cuts where necessary. Science and Innovation Minister Wayne Mapp announces success in a project of internships for undergraduate students:

We have huge demand from businesses so this year we have decided to award 341 internships instead of the 200 we initially intended...

Many of the interns from previous years later found jobs with the business (Mapp, 2011).

Students and businesses mutually benefit, as a result of competent mediation by the government. The Tertiary Education Union has criticised recent education policy for only prioritising marketable areas of education, an approach which has led to cuts (TEU, 2013). Mapp's release typifies marketisation in its emphasis on private sector internships, yet the discourse is one of growth rather than cuts. Neoliberalism, like parliamentary representation, provides the zero value of announcements; the assumed terms of social engagement (Levi Strauss, 1963), never named as the driving factor in education policy. PM John Key expresses the aspirational project that ideologically justifies a neoliberal programme for education:

We have a clear plan to build a better education system and make sure New Zealanders learn the skills they need to succeed in the 21st Century (Key, 2011a).

Although focusing on education, this line also implies the nature of National's programme for addressing poverty; workers must become 'employable', skilled, high-wage, deserving. National offers social mobility, rather than redistribution. This is a departure from classic One Nation Conservatism, which tended to recognise that many were poor through no fault of their own (Dorey, 2010). However the emphasis on addressing poverty by changing the behaviour of the poor, without curbing the rich in any way, matches UK post-Thatcherist conservative discourse (p. 182).

Terms like "partnership" and "mixed" equate corporate interests with the general interest. The National Party often employs a discourse of 'partnership' in its press releases. In the press releases surveyed, 
the National party uses the term 'partnership' not only in endorsing the controversial Trans Pacific Partnership Agreement, but also terming Charter Schools as Partnership Schools (Parata, 2014), referring to 'partnership' between employers and unions in the Christchurch rebuild (Wilkinson, 2011), promoting Public-Private Partnerships for broadband internet (Joyce, 2011), 'BlueGreen' partnerships with business to conserve the environment (Smith, 2014b), partnership with businesses in the primary sector (Guy, 2014) and "New Zealand's first-ever Public Private Partnership contract for a state highway" (Brownlee, 2014). 'Partnership' operates at meta-discursive level, framing various policies. Through 'Partnership', inequalities are bracketed, business joins and serves the community, and the ruling party secures appropriate contracts. Similarly, the National Party terms its programme of partially privatising state-owned assets a "mixed ownership model" (Joyce, 2011), subtly implying a partial departure from neoliberalism along the lines of 'Third Way' discourse ${ }^{16}$ which maintains neoliberal defaults.

Dorey (2010) notes an emphasis in UK Post-Thatcherist conservative discourse on the 'third sector', community organisations filling gaps left by the state and business (p. 182). This departs discursively from the neoliberal emphasis on the individual, without challenging the fundamentals of neoliberalism. The National Party similarly emphasises 'community' organisations as a mediating force between economic and social imperatives. Press releases advertise a "Community Response Fund" for voluntary groups responding to the Christchurch earthquake and Global Financial Crisis (Parata, 2011b) and a "Community Conservation Partnership Fund" for natural heritage groups (Smith, 2014c). Although these are reconcilable with neoliberalism, they offer an apparent buffer. Through these isolated conciliatory forms, the ruling party attempts to reconcile social demands with the prevailing regime. Associate Minister for the Community and Voluntary Sector Hekia Parata (2011b) is quick to emphasise that, by relying on community rather than state organisations, the "red tape" of state involvement can be avoided - implicitly, budgets can remain austere through the outsourcing of social tasks, often to voluntary labour. The National Party's regular use of "Community" offers a kind of euphemism for the

\section{6}

Initially a project of Labour Parties and associated theorists (Giddens, 1998), Third Way discourse seeks a path between social democracy and neoliberalism, which arguably embeds neoliberalism further (Kelsey, 2016). I suggest that this discourse has since been adopted by conservative parties in light of the unpopularity of neoliberalism. 
retreat of the welfare state.

In a neoliberal context, the National Party's programme can be characterised as bourgeois internationalist (cooperating across borders with business interests). National was the most likely party to use the term 'international' (Figure 8). The interests of international business are equated with the interests of New Zealand business, and therefore the interests of the nation as a whole:

Mr Key said enhancing and growing New Zealand's international trade links was a key part of our plan to build a stronger economy and create more jobs with higher incomes (Key, 2011c; emphasis mine).

The term 'international' most often occurred in reference to international trade agreements. Press releases promote the Trans Pacific Partnership Agreement (Groser, 2011a), the Thailand-NZ Closer Economic Partnership Agreement (Groser, 2011b), a Free Trade Agreemeent with Korea, and a WTO Agreement (Joyce, 2014d). Kelsey contends that such trade agreements are a global form of "economic constitutionalism," binding future governments to a neoliberal regulatory model (p. 208). For Stephen Joyce, Minister of Economic Development, these agreements mean that "our exporters can compete on an equal footing in other economies and further lift our exports" (Joyce, 2014d; emphasis mine). The first-person collective pronoun invites the reader to understand that what benefits New Zealand business; in this case, international regulatory integration; will benefit New Zealand as a whole. Similarly when discussing debt reduction, Joyce uses first-person collective pronouns to articulate a chain of equivalence:

With the current global economic uncertainty, it is crucial for us to get back in surplus quickly, and reduce our borrowing sooner rather than later. Kiwis know that means controlling expenditure, encouraging companies to grow, and building new infrastructure from the mixed ownership model, rather than more debt (Joyce, 2011; emphasis mine).

Through the terms 'we' and 'our', the interests of business are equated with the interests of all New Zealanders. The reader, not necessarily wealthy, is expected to identify with the concerns of business. Notably, the paragraph actually blurs crucial economic facts; stating public debt must be curbed, when New Zealand's public debt is relatively low (IMF, 2014), and our private debt is much more significant (Hunt, 2014), a problem which might imply curbing the housing boom or increasing incomes. Cognitive 
linguist and political theorist George Lakoff (2004) notes that facts can be less important than cognitive 'frames' for understanding political discourse (p. 73). In Joyce's above formulation, the precise economic nature of debt is less important discursively than the 'we' which binds the economic interests of state, capital and civil society. Instead of a collection of disparate people who have competing class interests, the nation is often imagined metaphorically as a family (p. 5). Joyce's call for discipline ('reduce our borrowing', 'controlling expenditure') may imply a conservative strict father model, whereby the father must ensure discipline for the ultimate wellbeing of the family (p. 40).

Beyond the content analysis, further media sources indicate the relationship between the leader's persona and the political programme of institutionalism. Dorey (2009) notes that David Cameron's election was a key moment in the UK Conservative Party's consolidation of post-Thatcherist discourse (p. 260). John Key's persona, criticised as apolitical (Brown, 2011), similarly gives expression to the National Party's contemporary institutional discourse. Key thrives on 'non-political' media appearances to shore up his popularity, courting publics through entertainment media (ibid). One critic has complained that Key's media persona represents not only an "absence of politics," but a "Politics of Absence" (ibid), operating as a kind of empty vessel that publics may project their aspirations onto. Other commentators have described Key's persona as the "CEO of NZ Inc" (MacDonald, 2016; KAROL, 2013; Pablo, 2012). Laclau (2005b) asserts that in the ideal Institutional form, which is impossible yet tendentially lurking, "politics is replaced by administration and the traces of social division disappear" ( $p$. 48). Key's apparently 'apolitical' media persona, rather than distracting from the National Party programme, gives expression to this programme. If government is simply the administration of objective (unchallengeable) social difference, publics do not necessarily require interrogation of their leaders by an engaged media. Key is a friendly boss, a competent manager integrating the private and public sectors, a politician from a world that has left politics behind; New Zealand after Fukuyama's End of History (whereby class and ideological conflict has come to an end, with social and economic liberalism prevailing over all competitors). 


\section{Labour's nationalist 'we'}

This chapter has covered how the nation-state is the primary site of identification for the two major parties. The critical discourse analysis seeks to identify the distinct ways the two major parties seek to appropriate the 'floating signifier' of the nation. Drawing on Laclau (2005a, 2005b), critical discourse analysis has demonstrated that the ruling party articulates an institutionalist discourse whereby the ruling party serves the national interest, by doing what is best for business. The next section argues that Right-Wing Populism is the dominant discourse of Opposition parties, particularly Labour. Opposition parties were more likely than their Government counterparts to refer negatively to 'foreign' actors. The Labour Party displaced economic anxieties, denied by National, onto racialised 'foreign' nonpublics. In the case of the housing bubble, a growing crisis demanded response, driven by the contradiction between use value and exchange value in Marxist terms (Harvey, 2014). Neither of the major parties identified class contradiction as a core element of the housing crisis. Whereas National denied ${ }^{17}$ the existence of a housing crisis, Labour's response to bourgeois internationalism displaced the economic contradiction through an ideological contradiction between local and foreigner. Labour failed to distinguish working-class migrants from international capital, focusing on Chinese 'surnames' (Gibson, 2015), a racial rather than economic characteristic. Labour's Right-Wing Populism sought to rouse opposition to neoliberalism without fundamentally challenging the common terms of the regime.

Like the ruling party, Labour's use of 'we' and 'our' indicates a representative relation between party and nation. However, Labour's invocation of the 'we' has a more negative 'they', where it's often a passionless site of bureaucratic specification for the ruling party. The following quote, on partial privatisation of power companies, is typical of mainstream oppositional discourses in 2011 and 2014:

[The assets] are ours, we already own them. We don't want them sold and we don't want Australian bankers pocketing $\$ 100 \mathrm{~m}$ as they clip the ticket during the sale (Goff, 2011; emphasis mine).

Labour's 'we' is at once more expansive and more particular than National's - whereas National's 'we' indicates what the party will do for New Zealand, Labour's 'we' identifies New Zealand with the party, excluding foreign elements. Labour's statements against asset sales use a nationalist 'us and them'

17 As of late August 2016, Key has conceded the existence of a housing crisis after years of pressure (Satherly, 2016). However, Key evaded responsibility for the crisis, blaming the previous Labour government (ibid). 
discourse:

Is that the future we want --- a future where the electricity we use every day to power our industry and heat our homes is more expensive because foreign buyers want to squeeze all the profit they can out of our country? That's what will happen if a National government is reelected (Cunliffe, 2011a).

Residential power prices have already increased exponentially in the decades since the Fourth Labour government's commercialisation of State-Owned Enterprises in the 1980s (Figure 7), which strictly speaking, kept the ownership in the hands of the New Zealand state. However, the crucial point here is that while National's 'we' was confidently managerial, Labour's 'we' invokes an abandoned, disenfranchised public, anxious about the actions of the neoliberal ruling party. National's 'we' is the executive wing of an objective, differentiated totality; the Institution. Labour's 'we' is a site of identification in a battle. They have betrayed us, and our day of reckoning will come.

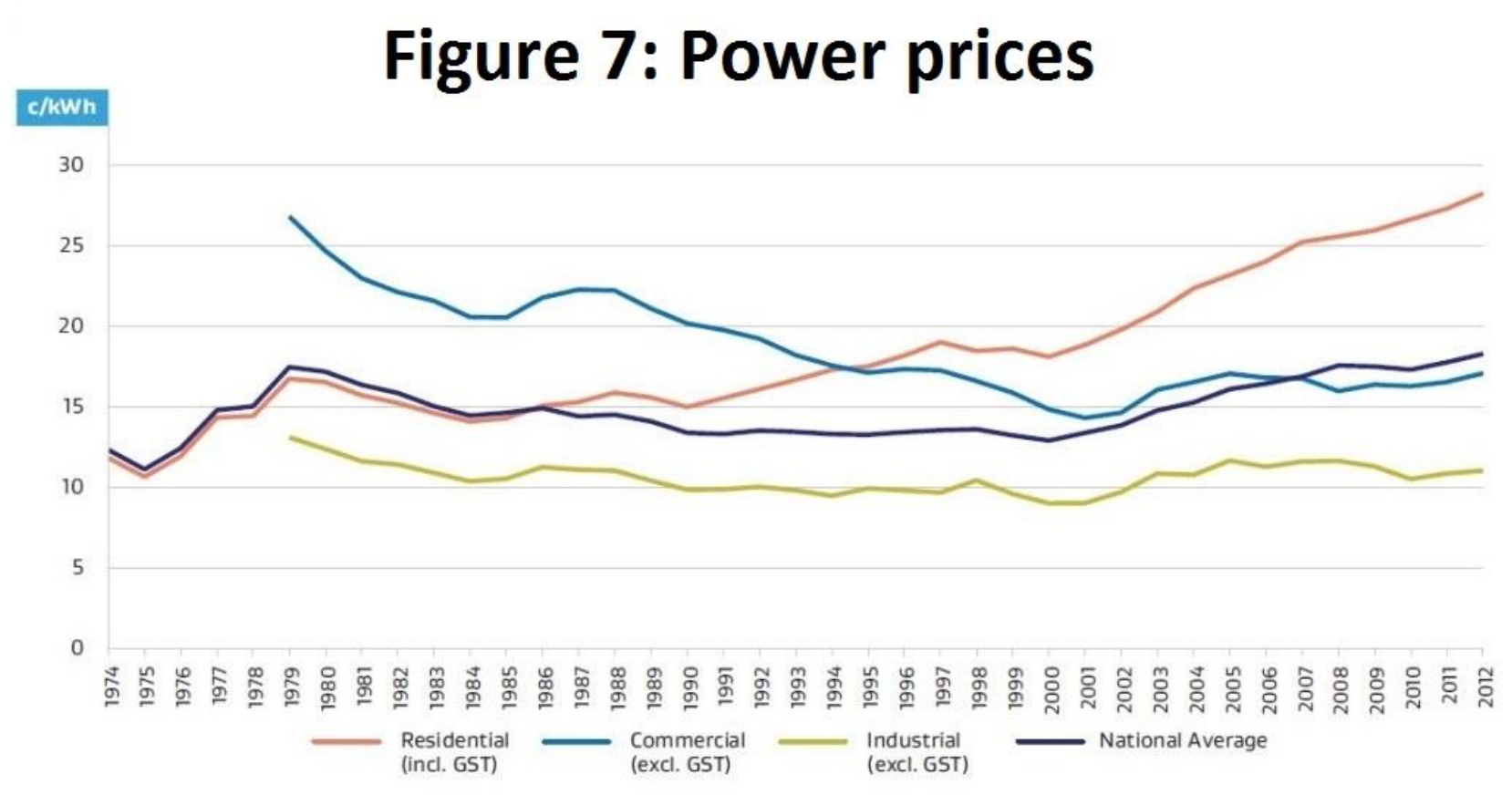

For Laclau (2005a), polarisation is the key difference between Institutionalist and Populist articulation - populism constitutes a 'people' defined by a dichotomous frontier, disrupting the wholeness of Institutional articulation:

The difference between a populist and an institutionalist totalization is to be found at the level of 
these privileged, hegemonic signifiers which structure, as nodal points, the ensemble of a discursive formation... in the case of populism: a frontier of exclusion divides society into two camps. The 'people', in that case, is something less than the totality of the members of the community (p. 81).

Although 'New Zealand' is the dominant cross-partisan site of identification, a 'floating signifier' in Laclau's terms, for Labour this is a site of polarisation rather than a site of reconciliation. This polarisation can be most clearly identified through the opposing term, the term of nationalism-bynegation; not 'New Zealander', but 'foreigner'. The Labour Party is the most likely party to use the term 'foreign(er)' in the content surveyed, using the term 35 times, followed by the other Opposition parties; MANA, the Greens and New Zealand First (Figure 8). The ruling National Party never uses this term, more likely to use the term 'international'.

Figure 8: National \& ethnic terms, party releases 2011-2014

\begin{tabular}{|c|c|c|c|c|c|c|c|c|c|c|}
\hline 100: National \& ethnic & ACT & Green & IP & Labour & MANA & Maori & National & NZF & UF & Total \\
\hline 101: New Zealand(er) & 25 & 161 & 10 & 203 & 78 & 39 & 380 & 86 & 21 & 982 \\
\hline 102: Kiwi & 2 & 10 & 0 & 111 & 1 & 1 & 25 & 5 & 2 & 155 \\
\hline 103: Nation (national) & 0 & 7 & 1 & 23 & 18 & 16 & 30 & 2 & 2 & 97 \\
\hline 104: Citizen & 0 & 0 & 0 & 3 & 3 & 2 & 2 & 2 & 0 & 12 \\
\hline 105: Pakeha & 1 & 0 & 0 & 1 & 1 & 2 & 0 & 0 & 0 & 5 \\
\hline 106: Maori & 2 & 0 & 0 & 20 & 163 & 100 & 67 & 10 & 0 & 362 \\
\hline 107: Non-Maori & 0 & 0 & 0 & 0 & 2 & 3 & 0 & 0 & 0 & 5 \\
\hline 108: Australia(n) & 1 & 0 & 0 & 49 & 7 & 1 & 35 & 7 & 0 & 100 \\
\hline 109: Pacific (Pasifika) & 0 & 0 & 0 & 56 & 16 & 10 & 46 & 0 & 0 & 128 \\
\hline 110: Samoa(n) & 0 & 0 & 0 & 17 & 2 & 0 & 16 & 0 & 0 & 35 \\
\hline 111: Cook Islands & 0 & 0 & 0 & 0 & 1 & 0 & 0 & 0 & 0 & 1 \\
\hline 112: Tonga(n) & 0 & 0 & 0 & 1 & 1 & 0 & 0 & 0 & 0 & 2 \\
\hline 113: Nive(an) & 0 & 0 & 0 & 0 & 1 & 0 & 0 & 0 & 0 & 1 \\
\hline 114: Fiji(an) & 0 & 0 & 0 & 1 & 0 & 0 & 11 & 0 & 0 & 12 \\
\hline 115: Tokelav(an) & 0 & 0 & 0 & 0 & 0 & 0 & 0 & 0 & 0 & 0 \\
\hline 116: Middle East(ern) & 0 & 0 & 0 & 0 & 0 & 0 & 0 & 1 & 0 & 1 \\
\hline 117: Asia(n) & 0 & 0 & 0 & 1 & 0 & 3 & 17 & 1 & 0 & 22 \\
\hline 118: Chinese & 2 & 0 & 0 & 2 & 0 & 0 & 0 & 0 & 0 & 4 \\
\hline 119: Europe(an) & 0 & 0 & 0 & 2 & 4 & 1 & 3 & 1 & 0 & 11 \\
\hline 120: British & 0 & 0 & 0 & 0 & 0 & 0 & 0 & 2 & 0 & 2 \\
\hline 121: Africa(n) & 0 & 0 & 0 & 1 & 1 & 0 & 1 & 0 & 0 & 3 \\
\hline 122: America(n) & 1 & 3 & 0 & 3 & 3 & 1 & 2 & 1 & 0 & 14 \\
\hline 123: Migrant & 0 & 0 & 0 & 1 & 2 & 1 & 0 & 0 & 0 & 4 \\
\hline 124: Refugee & 0 & 0 & 0 & 0 & 0 & 1 & 1 & 0 & 0 & 2 \\
\hline 125: Foreign(er) & 0 & 13 & 0 & 35 & 14 & 8 & 0 & 12 & 0 & 82 \\
\hline 126: International & 0 & 2 & 4 & 11 & 9 & 4 & 30 & 0 & 0 & 60 \\
\hline
\end{tabular}

For the opposition parties (Greens, Labour, MANA, New Zealand First), foreigners are an economically parasitic nonpublic, threatening and undermining the nation. In addition to sale of power companies into "foreign ownership," Labour expresses concern about the sale of farmland to a Chinese buyer (Parker, 2011). The potential New Zealand buyer in this case was Michael Fay, one of the ten richest men in 
New Zealand, having making substantial profits from the privatisation of telecommunication and rail infrastructure (Bennett, 2012). Privatisation does not necessarily move assets into 'foreign' hands so much as capitalist hands, both local and international. However, Labour maintains the primacy of the local/foreign divide over the class divide, never naming 'capitalists', 'millionaires'18, 'billionaires', 'corporations' or 'big business' as threats. Their only mention of 'investors' unfavourably contrasts "foreign investors" with "Kiwi investors" (Cunliffe, 2011b), and their only mentions of 'bankers' specifies "Australian bankers" (Goff, 2011a). This balances the courting of a dispossessed public with the need to remain business-friendly, perhaps keeping in mind that businesses still fund both major parties (Edwards, 2008, p. 5). Questions of economic (mal)distribution are displaced through national (mis)recognition.

A controversy in 2015 , outside of the content analysis but useful in contextualising the content, provides an example of Labour's right-wing populist discourse. Labour housing spokesman Phil Twyford released a leaked report, covering around 4,000 Auckland house sales by one firm, underlining that $39.5 \%$ of those purchases were conducted by buyers with "Chinese surnames" (Gibson, 2015). Twyford considered this "staggering evidence" of offshore purchasing, although there was no way of differentiating between Chinese New Zealanders and overseas investors (ibid). Labour quickly received a backlash from members of the Chinese community for "half-baked" figures and for treating Chinese buyers as "scapegoats" (Walters, 2015). By defining economic exploiters as foreign, specifically Asian, this gesture also implied a certain national identification for legitimate home-owners: 'Kiwi', implicitly European-descended, and apparently incapable of predatory economic behaviour. Keith $\mathrm{Ng}$ (2015) underlined the stereotypical, ethnically defined public and non-public implied by Twyford's account:

The subtext of this story is that people with Chinese-sounding names are foreigners full of cash who are buying all our houses and chasing hardworking Kiwis out of their homes. This is straight-up scapegoating (ibid).

Labour's emphasis on nationality fudged the economic contradictions at the heart of the housing crisis. As Sue Bradford (2016) notes in a discussion of left housing strategy in Aotearoa/NZ, xenophobia like Twyford's "can provide a 'quick hit' for popular support, but comes at the expense of promulgating an

18 Exception: Labour MP Kelvin Davis referred to Kim Dotcom as a "multimillionaire" in an interview (see Chapter 3 discussion). 
understanding of the deeper structural dynamics at play" (p. 159). Bradford notes that although a number of community groups are organising resistance to the neoliberal housing agenda, groups are largely fractured, often lacking a common language (p. 145-166). With the collapse of the housing boom lurking on the horizon, systemic analysis of the housing market should seek to clarify the relations mystified by Labour's xenophobia. For Harvey (2014), housing bubbles are a "perfect example" of the contradiction between use value and exchange value under capitalism (p. 23). If we consider housing as a right, we must place the 'use value' of houses first, their capacity to provide shelter (p. 18). However, the exchange value of houses, their price and profitability, moves into the "driver's seat" under capitalism (p. 17). As housing is a speculative commodity - usually purchased through debt - property bubbles are a regular feature of capitalism (p. 21). In the 2008 US housing crisis, "the pursuit of exchange value destroyed access to housing as a use value" (p. 21)

\section{Figure 9: House prices vs income}

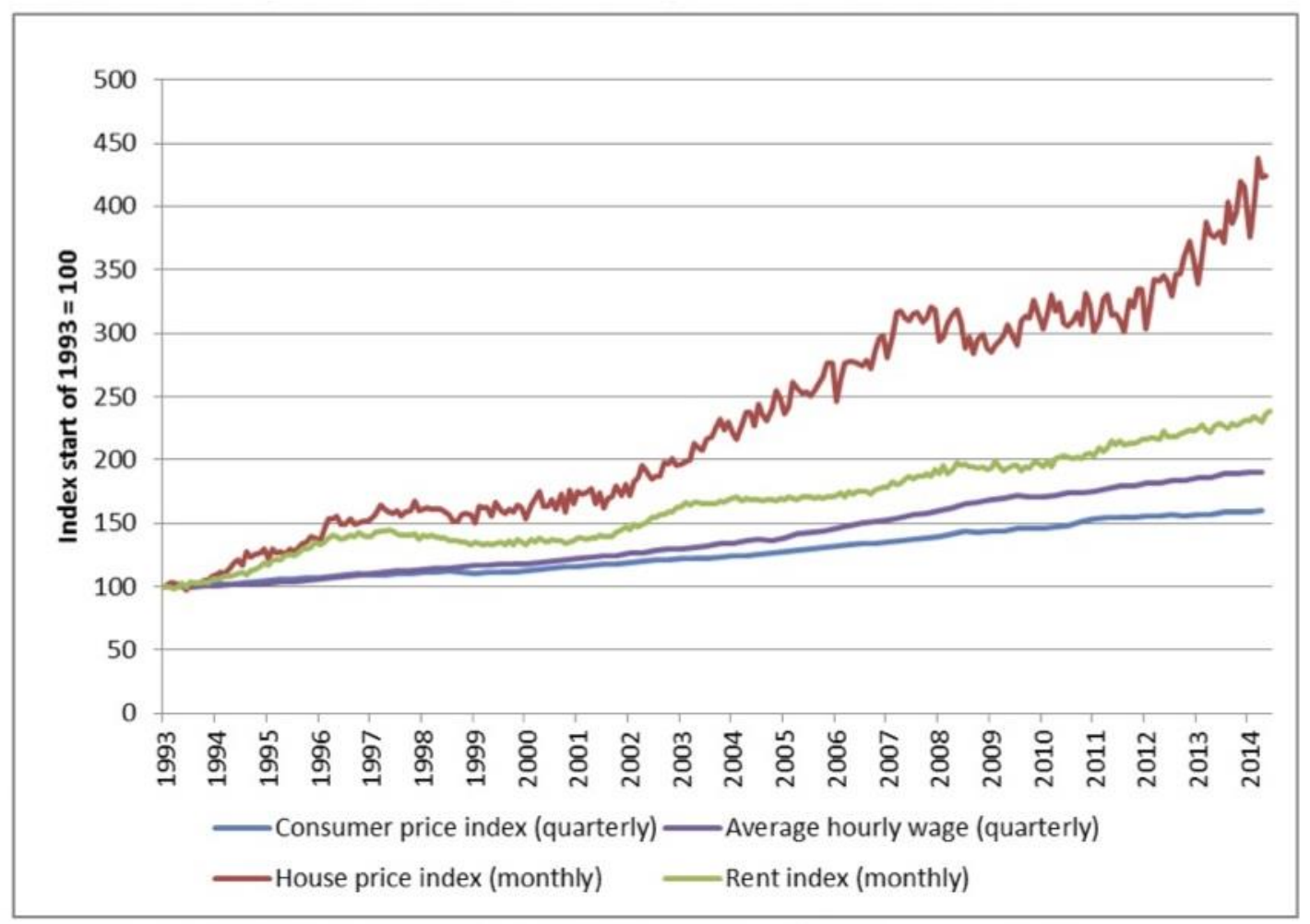

(Source: Statistics New Zealand, REINZ, Housing New Zealand, 2014)

The housing crisis presents a challenge that both major parties are apparently unwilling to address. Critical political economy may help in understanding their reticence. In Aotearoa/NZ, the housing bubble has yet to burst at the time of writing. House prices in Auckland quadrupled from 1991-2014, and wages 
have not kept up (Figure 9). The growth in exchange value already undermines the use value of housing; decreasing numbers of people can afford housing. Recent years have seen a drop in homeownership to just below 50\% of the adult population (Statistics New Zealand, 2014b). The same period has seen a $25 \%$ spike in homelessness (Amore, 2016). Although the government does not collect comprehensive stats on ownership of housing, data from Land Information New Zealand indicates that only $3 \%$ of buyers and sellers are foreign tax residents (LINZ, 2016). Harvey (2014) notes that many middle-class 'consumers' gain (precarious) wealth from the housing bubble, not only superrich investors: "housing asset values have become important political objectives for larger and larger segments of the population and a major political issue because the exchange value for consumers is as important as the exchange value earned by producers" (p. 20). Herein lies the contradiction for major parties; how to address the housing crisis without alienating voters who benefit from the boom; likely to be older and Pākehā, also demographics likely to vote (Statistics New Zealand, 2014a; Statistics New Zealand, 2014b). Rather than alienate this relatively privileged public, the major parties evade the problem. While the ruling party denies the tension entirely - John Key has claimed there is "no housing crisis" (Moir, 2015) - the main opposition party displaces it through the ideological contradiction between 'local' and 'foreign'. Growing social and economic contradictions among the people; between property owner and vagrant, mortgagee and lender, landlord and tenant; are safely displaced onto a nonpublic, an 'Other', defined through racial rather than economic characteristics. This tendency to externalise social contradiction onto 'foreigners' may be associated with the high representation of recent migrants in non-voting statistics, with over $60 \%$ of recent migrants not voting (Statistics New Zealand, 2014a). Those who "[d]o not feel they belong to New Zealand" are also heavily represented in non-voting statistics (ibid).

National and Labour's apparently distinct responses to the crisis both give tacit leeway to local capital, which otherwise may be destabilised by left-wing responses to a growing political-economic crisis. Yet in Labour's discourse, "a frontier of exclusion divides society into two camps," Laclau's (2005a) precondition for populist as distinct from institutional articulation (p. 81). Whereas National's institutional discourse is bourgeois internationalist, Labour's Opposition discourse is bourgeois nationalist. Although Labour's economic populism may appeal to left-wing or subaltern publics, their specific focus on the threat of foreign over local capital venerates the purified singular nation-state, a cross-class alliance, as 
solution to the uncertainties of international capitalism. This is Right-Wing Populism. Although Labour's is a weak populism - perhaps lacking a sufficiently compelling leader figure, which for Laclau is "inherent to the formation of a 'people"' (p. 100) - they use the formulae of populism, the dichotomous yet imprecise terms (migrants are confused with international capital). Populism emerges from a notion of unfulfillment, a need for restoration of wholeness:

From the very beginning we are confronted with a dichotomic division between unfulfilled social demands, on the one hand, and an unresponsive power, on the other. Here we begin to see why the plebs sees itself as the populus, the part as the whole: since the fullness of the community is merely the imaginary reverse of a situation lived as deficient being, those who are responsible for this cannot be a legitimate part of the community: the chasm between them is irretrievable (Laclau, 2005a, p. 86).

The nation, as common site of identification, offers a hinge for such polarising discourse without threatening the class basis of the common regime. As Gurhanli (2013) notes in comparing Laclau's categories with those of conservative political theorist Michael Oakeshott, populist discourse can opportunistically manipulate the status quo rather than radically subverting it (p. 35). I contend that the difference between Institutionalism and Right-Wing Populism is more tactical than strategic, both hailing publics in support of local bourgeois power. 


\section{Chapter 2: Recognition of the Subaltern}

Having established features of dominant party discourse, my analysis now moves on to consider its discursive relationship to subalterns. This chapter demonstrates a tendency of dominant discourse to officially 'recognise' culturally subalttern groups, while splitting these groups into (recognised) economic elites and (unrecognised) economic subalterns. This analysis is framed by a 'tripod' of subaltern publics; Racialised, Gendered and Economically defined publics. Culturally subaltern groups (Māori, women) are named more than dominant groups (Pākehā, men); dominant groups are invisible, default, implicit in generic terms like 'New Zealander' or 'taxpayer'. This is the dominant norm across both party and press coverage in 2011 and 2014: a 'common ground' for politics. Having established this pattern in the content, the chapter proceeds to critical discourse analysis in an attempt to reveal underlying power structures.

The National Party's official discourse on 'Māori Affairs' enacts a programme of bourgeois hegemony in the field of cultural recognition (Section I). The Party rushes for 'settlement', seeking to foreclose the articulation of indigenous grievances. Yet over a period of increased settlement, inequality has only increased. The National Party emphasises cultural recognition of an economically privileged layer, without adequate measures to address the poverty of most Māori. The National Party's programme for women also trades recognition for redistribution (Section II). While the party celebrates formal equality, and recognises the achievements of bourgeois women, poor and working-class women do not find the same recognition. Rather, poor women are attacked through categories such as 'beneficiary'. Press coverage also equates working-class identity with masculinity, despite the feminisation of poverty and the fact that the majority of union members in Aotearoa/New Zealand are women (Ryall \& Blumenfield, 2014; p. 9). As in Nancy Fraser's (2005) account of feminism, the movement gains recognition without redistribution, in a "tragic" bargain which defangs feminism and other social movements (p. 299).

Economic categories tend to be more generic than explicitly Racialised and Gendered categories, with classless terms like 'the market' and 'the economy' rife in dominant discourse (Section III). Without specification of class relations, these generic terms reify economic relations as simply the terrain of existence, rather than a historically specific social relation that could be overturned. Conversely, the bourgeoisie is assumed to be a universal class, as the interests of business are equated with the 
interests of New Zealand as a whole. Content in 2011 briefly diverges from this norm with the emergence of the MANA Movement, a party which articulates a Left-Wing Populist polarisation between 'rich' and 'poor'. While MANA at times reflects the dominant Right-Wing Populism of Opposition parties (emphasising national over class division), the party also articulates a nascent Left-Wing Populism, seeking an alliance between Māori and Pākehā publics on the basis of working-class constituency. Even as a minor party, MANA finds some mainstream media coverage for its challenges to the inequalities fostered by neoliberal capitalism. 


\section{Figure 10: 'Maori' / 'Pakeha' 2011-2014}

\section{party releases}

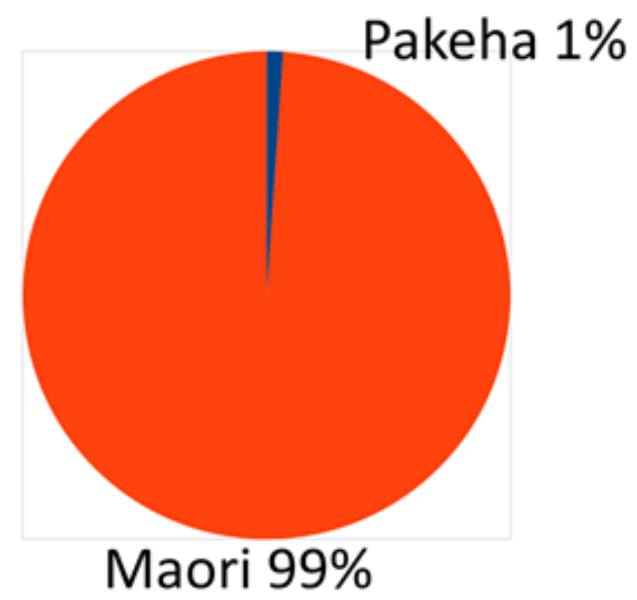

press coverage

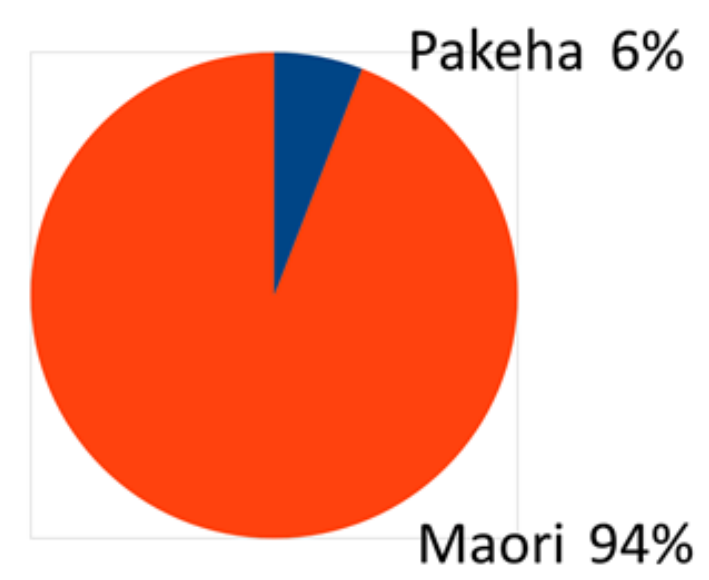

\section{I.Recognition of the Indigenous subaltern}

The section begins with a quantitative comparison between 'Māori' and 'Pākehā' as terms in dominant discourse. Pākehā are largely invisible, at $1 \%$ of party mentions and $6 \%$ of press mentions (Figure 10). As in Sara Ahmed's Phenomonenology of Whiteness (2007), whiteness is a "habit" (p. 149), a "background to experience" (150), even a surrounding "space" (157). Black and brown bodies, or Māori bodies in this case, "interrupt" the space of whiteness (153), are "noticed" in a way that white bodies are not (157). Whiteness already exists, unnamed, embedded in generic terms like 'New Zealander'. Pākehā emerge only in relation to Māori - in 2011, 8 out of the Herald's 9 references to Pākehā refer to members of MANA, a party founded and led by Māori (to be discussed in Section III):

"Pakeha candidates John Minto and Sue Bradford" (Collins et al, 2011), "Hone's date with Pakeha" (Crispe, 2011).

Counterintuitively, the dominant group is the least visible, only emerging in relation to the subaltern group (in this case Pākehā only emerge in a party with Māori leaders). By contrast, the ruling party continuously reasserts recognition of the subaltern, albeit on terms that reproduce dominant bourgeois terms. The National Party's official discourse enacts a programme of bourgeois hegemony in the field of cultural recognition. Three press releases released on the same day, the 12th of September 2014, outline the National Party programme of recognition, redistribution and representation for Māori: 'Treaty and Māori Affairs policies released' (Finlayson, 2014), 'National targets more skills training for Māori' 
(Joyce, 2014a), and 'Ten key initiatives to boost Northland ${ }^{19}$ Economy' (Joyce, 2014b). Variations on the term settle ('settling,' 'settlement') appear 11 times in the short document 'Treaty and Māori Affairs policies released' (Finlayson, 2014). The piece underlines the speed of settlement, boasting of more settlements per year than the previous Labour government, and a target of finalising settlements in 2017. As Veracini (2012) contends, settler-colonial polities have largely shifted from direct repression to "incorporation by recognition" (p. 8). This shift seeks a final "settled" resolution, in contrast to more open-ended approaches (p. 9). While this release may be partly intended for iwi publics, the call for final resolution may also be intended for discontented Pākehā. National's release states that settlement "is good for iwi and good for New Zealand" (Finlayson, 2014), implying a distinction between 'iwi' and 'New Zealand', thereby embedding the invisibility of Pākehā identity, cloaked under the national category. The release adds that the process will "allow us to move forward as a nation" (Finlayson, 2014), underlining how 'settlement' serves the nation as a whole. Recognition of indigeneity is desirable so long as it immediately abolishes itself: through recognition, the indigenous figure is assimiliated into the diverse, yet unified nation-state. Whereas the Pākehā citizen is always-already the neutral subject of the national project, the Māori citizen may be recognised on the condition that she give up her struggle for recognition.

Finlayson (2014) outlines a notion of economic redistribution when he states that settlements "provide iwi with an economic base to build on." All Māori have iwi whakapapa ('tribal descent'), and many are affiliated to modern iwi organisations. However, National's emphasis on 'iwi' arguably prioritises bourgeois iwi leaders over the majority of Māori. Historical context may help to contextualise this partial recognition: constitutional lawyer Annette Sykes $^{20}$ (2010) contends that the National Iwi Chairs Forum, established as "first in the queue to sit at the Masters table," (p. 4), is a self-elected body that has helped entrench "a new Māori hegemony" implementing neoliberalism (p. 8-17). Rather than broader redistribution, National recognises indigenous leaders with bourgeois economic interests. Over a period of increased 'settlement,' inequality has only increased within Māori communities (Poata-Smith, 2005). The National Party's stated programme for economic redistribution centres on two key mechanisms:

\section{9}

Māori comprise $32 \%$ of the Northland population.

20 Sykes would later stand as a candidate for the MANA Party, which had not formed at the time of writing The Politics of the Brown Table (2010). 
private profit from iwi land ownership, and skills training (Finlayson, 2014; Joyce, 2014a; Joyce, 2014b). The party underlines skills training, with the Māori and Pacific Trades Training Initiative expanding by 2000 places (Joyce, 2014). Over half of Māori and Pasifika workers are considered to work in 'lower skilled' occupations (SNZ, 2013). Many of these jobs are essential: manufacturing, cleaning, care work (ibid). National's economic programme for Māori assumes the low value of these lines of work, and rather than raising wages for 'lower skilled' workers, proposes upskilling. National's Māori Affairs policy also outlines limited economic concessions to social policy - e.g. expanding free early childhood education, increased health funding to fight diseases (Finlayson, 2014). These minor social concessions must be placed in a broader historical context. In Gramsci's terms, the National Party operates as a "hegemonic" organisation, rather than a simply "economic-corporate" fraction implementing policy not just to meet bourgeois economic needs, but to seek consent from subaltern layers (Gramsci, 2011b, p. 179-180; p. 183-184). Maintaining state power requires that superstructures are developed to carry out these broader social tasks, "or else the state will fall apart" (p. 197). National's social policies remain firmly within the monetary and fiscal regime of neoliberal capitalism (Kelsey, 2015). Limited amounts of capital are allocated for treaty settlements, healthcare and education, without challenging the economic base. Alongside these limited social policies, National proposes controversial policies that extend capitalist exploitation - "Encouraging minerals exploration and oil and gas exploration" is promoted as necessary to economic development in Northland, without acknowledging local concerns about sustainability (Joyce, 2014b). A Waitangi Tribunal report has criticised the National Party's Te Ture Whenua bill, trumpeted in these press releases, as commercialisation of Māori land without sufficient consultation (Bootham, 2016).

Recognition and redistribution are both mediated through a particular form of representation. In the closing paragraph of his Treaty and Māori Affairs policy release, Finlayson (2014) underlines that the government will continue to work with "iwi leaders," taken to represent Māori as a whole. Indigenous scholar Brendan Hokowhitu argues that this limited form of recognition casts the majority of urban Māori as a "corrupted and inauthentic form of Indigeneity," in part because poor and working-class urban Māori represent more of a threat to capitalism (p. 362-265). The majority of Māori remain dispossessed, and disengaged from parliamentary politics, overrepresented in non-voting statistics (Statistics New Zealand, 2014a). Fundamentally, Māori subjects can only be recognised so long as the terms of 
neoliberal capitalism remain unchallenged. This means recognising a selected economic layer, iwi leaders, as authentic indigenous subjects. As in Nancy Fraser's (2005) account of the "tragic historical irony" of contemporary feminism (which she claims is also relevant to other social movements), redistribution is traded away for partial recognition (p. 299). Whatever is good for the bourgeoisie is good for Māori, and for New Zealand: the part represents the whole. 


\section{Figure 11: 'Women' / 'Men' 2011-2014 party releases press coverage}
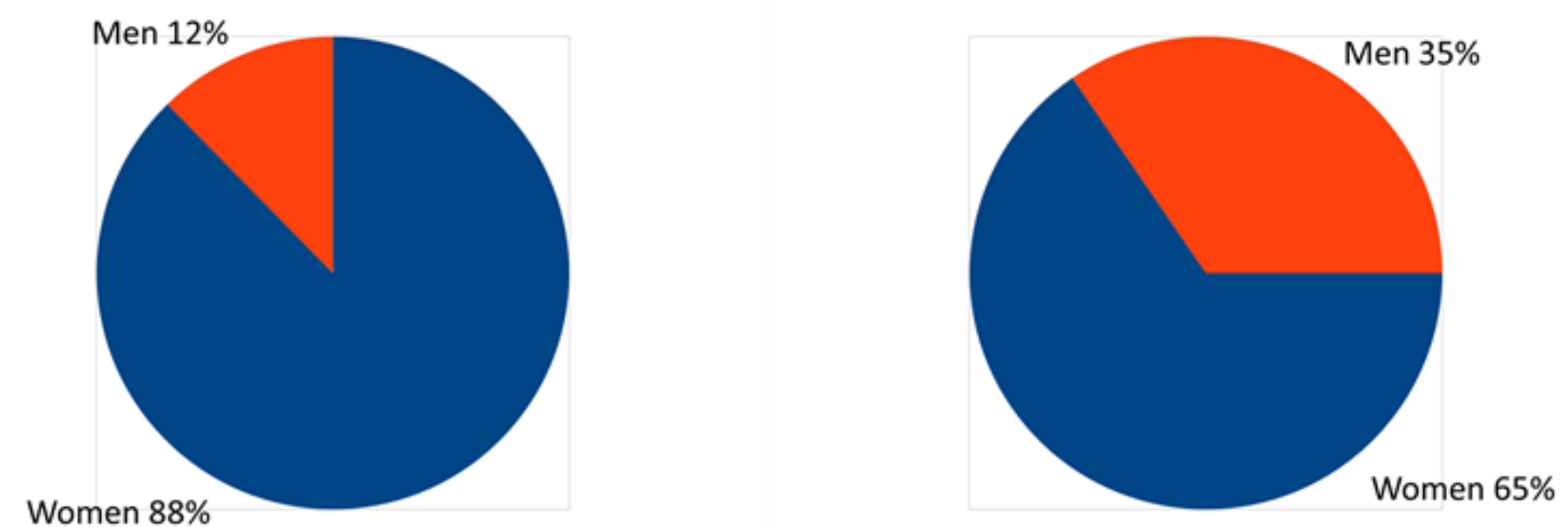

\section{Recognition of the Gendered Subaltern}

Broadly, comparing 'Men' and 'Women' reveals similar results to 'Māori' and 'Pākehā' - a greater tendency to name the subaltern group (Figure 11). Parliamentary parties invoke women as publics, through 'women's issues'; Women's Refuge (King, 2011), celebrating the right to vote (Goodhew, 2014) and equal pay (Delahunty, 2011). However, 'men' are named proportionately more than 'Pākehā' - even reaching $35 \%$ in press coverage, compared to $6 \%$ for Pākehā. Gender minorities are not mentioned at all (a point that will be expanded in Chapter 3). In some situations men are named in relation to women's rights; e.g. Labour MP Kelvin Davis asserts that "men should own domestic violence as a male problem" (Pagani, 2014). In these cases, the dominant emerges in relation to the subaltern, as in the discursive relationship between 'Māori' and 'Pākehā'.

However in other cases, the term 'men' is used more broadly or generically. In 2011 and 2014, the Labour Party leaders referred to the Pike River miners as 'men' (Goff, 2011; Cunliffe, 2014). This is unobjectionable on its own - the miners who died were men, in a male-dominated industry - however it indicates a more subtle tendency to equate masculinity with working-class identity. For example, New Zealand Herald article on Labour's electoral failings focused on a photo op in a West Coast mining town, emphasising an assumed relationship between working-class and male identity: "[MPs] obliged reporters' requests for muscular union-style poses" (Young, 2014c). The article then noted a recent poll showing male support of under $20 \%$, indicating that their "muscular union-style poses" were ineffective at winning over men (ibid). Finally, the implied association between gender and class was made explicit: 
Friday's DigiPoll gender breakdown showed that only 18.4 per cent of men supported Labour, an incredible low for the party founded by and for organised labour (ibid).

The reporter assumes an association between organised labour and masculinity. However, the majority of union members are women (Ryall \& Blumenfield, 2014; p. 9). This has been the case for over a decade (ibid). Press criticism is premised on an out-dated conception of class composition; assuming a majority-male union movement, which has not been the case for more than a decade. 'Women' and 'workers' are treated as distinct publics, arguably reflecting the separation of recognition and redistribution in ruling discourse, whereby recognition occurs on bourgeois terms. The relationship between gender and dominant political representation is debatable - unlike other culturally oppressed groups, women are about as likely as their male counterparts to vote (Statistics New Zealand, 2014a). However, in future surveys of non-voters, it may be worth investigating the role of double-oppression in political disenfranchisement - whether low-income women (dis)engage, considering that women are overrepresented among low-income groups.

The National Party political programme for women matches their programme for Māori: recognition without redistribution. Women's Affairs Minister Jo Goodhew outlines this programme in a release commemorating women's suffrage. Goodhew genuflects towards the nation, in keeping with the discourse that must run through all dominant political articulation:

We are all proud that New Zealand was the first nation in the world to grant women the vote on September 19th, 1893.

After an acknowledgement that there is still a ways to go, Goodhew commemorates women who have succeeded on terms acceptable to the bourgeoisie:

Today I have been inspired by our talented women who are leading innovation in science, business and society.

While these gains in bourgeois democratic rights may be a progressive result of prior feminist struggle, they do not necessarily address the concerns of multiply-oppressed women. Around $56 \%$ of solo parent families live in poverty, and $84.2 \%$ of those families are headed by women (Dwyer, 2015). Unlike women in business, solo mothers are not honoured by Jo Goodhew. National Party releases 
euphemistically refer to "support[ing] beneficiaries into work" and aiming to reduce benefit numbers by 25\% (Bennett, 2014), indicating this punitive approach to solo parents performing the unpaid childrearing necessary to reproduce social relations. As with Māori, a selected layer of women are recognised, while poor women are punished. 


\section{Figure 12: 3 most common economic terms}

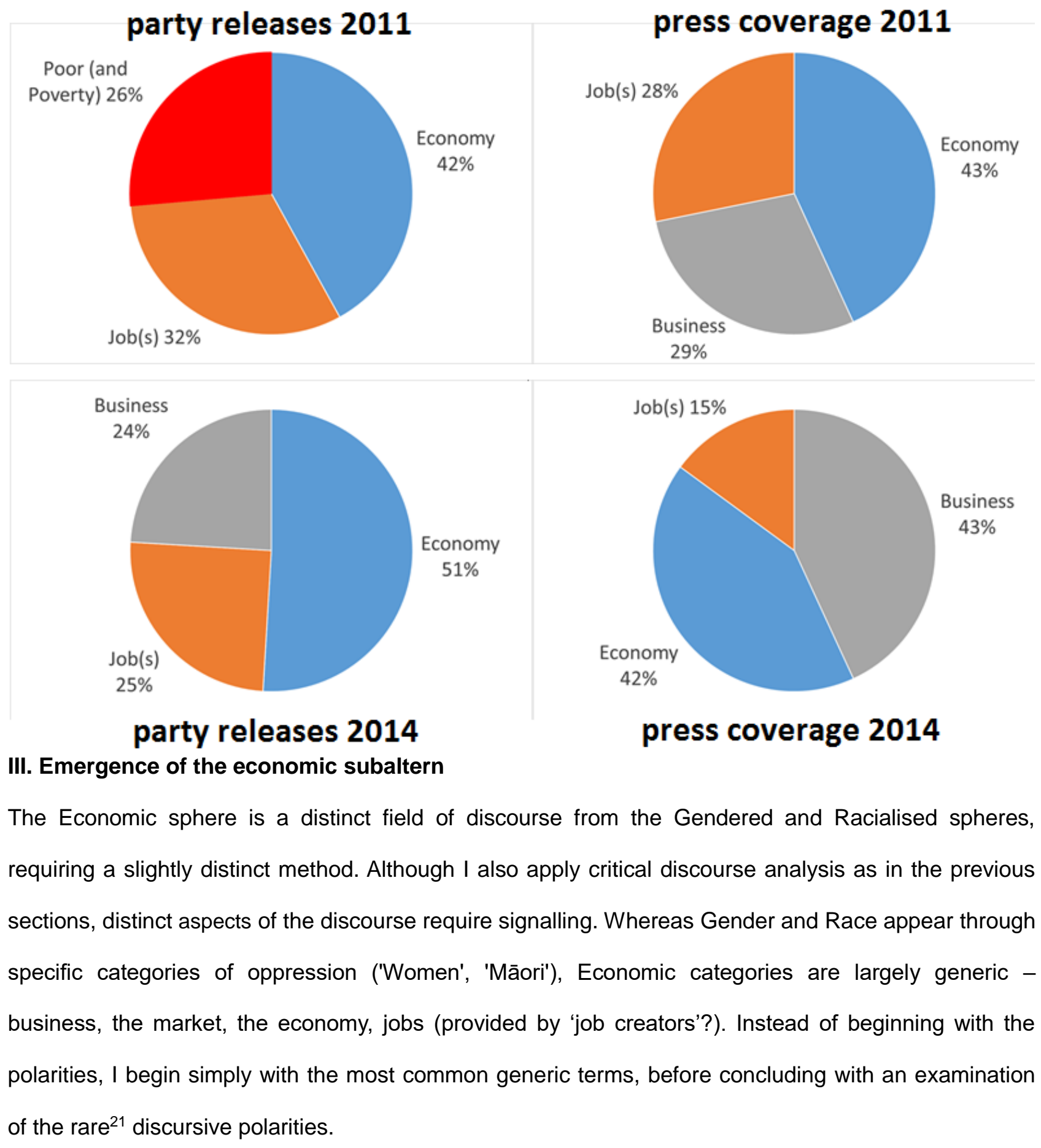

21

In previous cases I have generally merged the 2011 and 2014 data, as the patterns were consistent. However in this case, party releases in 2011 saw a major deviation from the dominant pattern: the emergence of 'the poor' as a significant category, in a field which tended to use more generic, less class-conscious categories. For now I am noting this more polarised language and bracketing it for later discussion. 
Across all party and press coverage, the 'Economy' was the most common term (tied with 'Business' in 2014 press coverage). While it may seem intuitive that 'the economy' is the most common Economic term, it has an ideological inflection, concealing and naturalising class contradiction beneath a generic term. From a different political perspective, 'Critical Political Economy' rather than 'the economy' might seek to specify the power relations of capitalism. One article defends 'the economy' from critics, as an abstract force over and above social actions:

Opposition parties seek to portray the economy as heading into a parlous state. It is not. The economy created 82,000 new jobs in the past year.

In this formulation, a set of social interactions - employment of workers by capitalists, trading of goods and services, transactions in the field of fictitious capital, imposition of laws and regulations - are not specified, and are rather homogenised under the generic category of 'the economy'. Causal and historical interactions are not clear, e.g. whether this growth in jobs is new, what the usual fluctuations in employment are, how government policies relate to growth, what industries have seen growth (or contraction), whether the new jobs are permanent or precarious. Instead of explaining any specific interactions between social actors, the writer simply attributes an apparently positive development to 'the economy', before moving on. Commodity exchange appears to take on its own venerated form of historical agency, independent of the people participating. As Lukacs (1923) describes in his account of reification ('thing-ification'), social relations assume a 'phantom objectivity':

[The commodity structure's] basis is that a relation between people takes on the character of a thing and thus acquires a 'phantom objectivity', an autonomy that seems so strictly rational and all-embracing as to conceal every trace of its fundamental nature: the relation between people.

Whereas Gender and Race oppression are uncomfortable truths that can perhaps be rectified through recognition, the 'market' is natural, universal, simply the space we inhabit. In Gendered and Racialised discourse, the subaltern group is more visible than the dominant. In mainstream Economic discourse, the line between subaltern and dominant, the existence of any stratification, is largely invisible.

Media coverage largely assumes identity of interests between readers and business, indicating bourgeois universality. A front-page banner before the 2014 election emphasises the $\$ 12$ billion promises from the two major parties. This emphasises the fiscal cost over other economic impacts. Conversely, New Zealand's public debt is relatively low (IMF, 2014). The impact of policies on inequality, 
or private debt, do not occupy the same default position as fiscal policy. Kelsey (2015) notes that the embedding of fiscal (or monetarist) policy was a key part of neoliberal entrenchment in Aotearoa/NZ ( $p$. 190). The default emphasis on fiscal policy implies that the reader, as a New Zealander, must identify with the interests of business. The interests of business are identical with the interests of the nation as a whole: this 'Institutional' discourse in the press is closely comparable with the ruling party's discourse covered in Chapter 1.

Business most clearly emerges as a constituency in the pages of the Business Herald. This is not complimented by a section on the labour-force, a larger section of the population than 'business' (primarily CEOs and other bourgeois figures). An annual Mood of the Boardroom survey, focused on the views of chief executives, carries a headline that explicitly articulates the premise of bourgeois universality: "Business confidence bodes well for everyone" (Business Herald, 2014). 97\% of those surveyed prefer a National government (ibid).

\section{Figure 13: Asset sales "bonanza"}

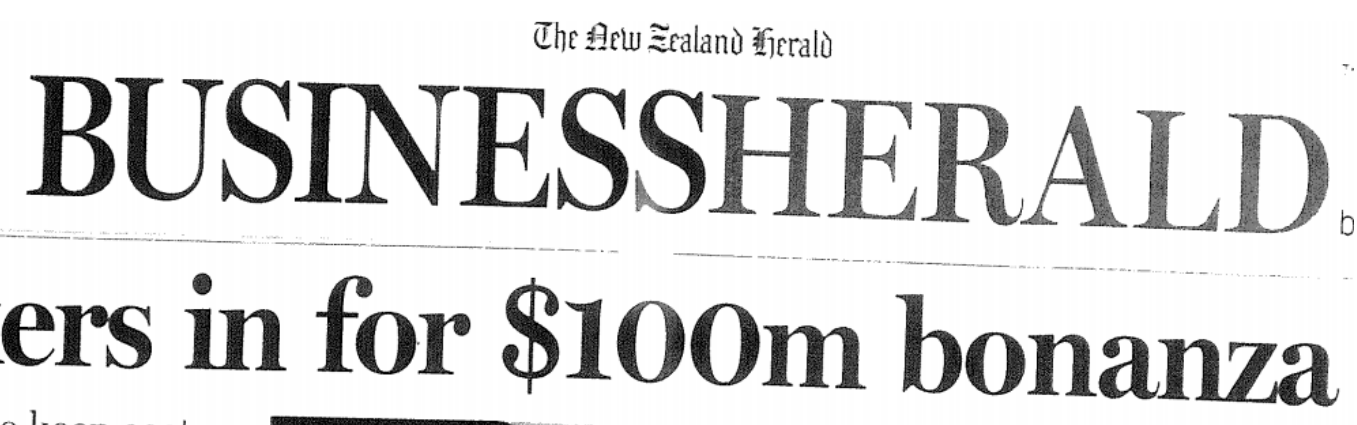

Firms warned to keep costs and brokerage fees moderate
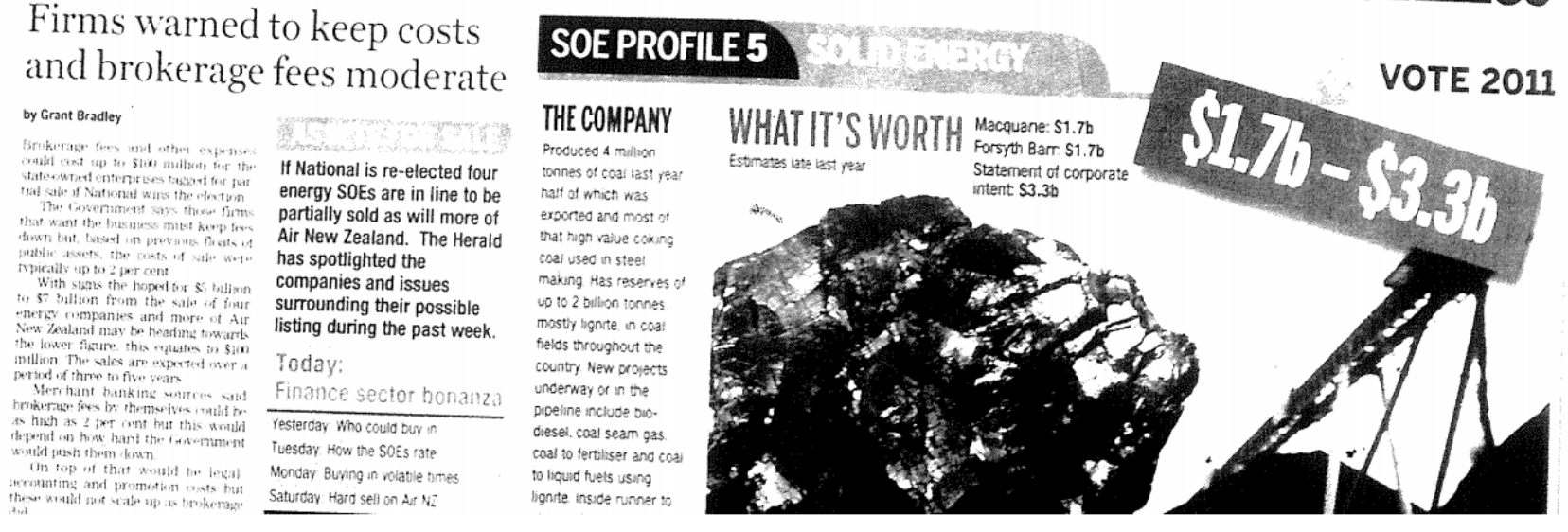

While coverage largely cloaked business interests under generic categories like 'the economy', the Business Herald openly celebrates neoliberal victory with the headline "Bankers in for $\$ 100 \mathrm{~m}$ bonanza" on the controversial asset sales policy (Figure 13), opposed by around two thirds of voters according to 
a Citizens-Initiated Referendum (Rutherford, 2013). Democracy seems incidental: what's best for business is best for everyone, whether they like it or not. This disconnection between democracy and policy may help explain why poor and working-class citizens increasingly disengage from the electoral process (Statistics New Zealand, 2014a).

While the Business Herald asserts the interests of the bourgeois public, MANA in 2011 represents the partial emergence of the subaltern as counterpublic. MANA formed from MP Hone Harawira's split from the Māori Party, over that party's economic concessions to the ruling National Party (Watson, Hartevelt, 2011). Populist discontent crystallised around the leader-figure of Hone Harawira, particularly in his electorate Te Tai Tokerau - populist movements tend to form around a leader-figure, who gives expression to discontent (Laclau, 2005a, p. 100). In the ferment of the party's 2011 formation, the party embodied a range of sometimes contradictory political currents. MANA in some respects reproduced broader Right-Wing Populist discourse, referring negatively to 'foreign' interests, alongside a nascent left-wing populism that departed from dominant Opposition discourse. I have discussed how nationalist ideology can displace class contradiction (Chapter 1). A Foreign Policy press release by MANA explicitly counterposes progressive internationalism with National's bourgeois internationalism:

MANA believes that the relationships between Aotearoa New Zealand and other peoples and countries must be shaped by our ethics of solidarity and manaakitanga and our vision for a just future, not by the interests of major powers and their corporations, as happens now... New Zealand governments send troops fight the super-powers' wars in other countries but fail to condemn abuses of human rights, especially of indigenous peoples, elsewhere... Mana stands for an ethical foreign policy (MANA, 2011).

As previously mentioned, content analysis reveals that 2011 party releases deviate ${ }^{22}$ from largely

22 Labour Party references to Insurance also grew in 2011, with 62 mentions (Table 2). These all concerned the aftermath of the Christchurch Earthquake, and associated insurance crisis. Labour repeated the following policy prescription in each press release on the topic: "Resolve the insurance gridlock... Intervene in the insurance market as a last resort... Establish an independent insurance commissioner." As this policy statement leaves policy prescriptions at a very general level, limits direct intervention to a 'last resort', and does not identify the broader systemic issue of neoliberalism, I do not consider this a major departure from prevailing discourse. 
generic Economic terms - the emergence of 'the poor' as a public. The newly formed MANA Movement was nearly single-handedly responsible for this deviation, with their 133 mentions ${ }^{23}$ of 'Poor' or 'Poverty' distantly followed by the Green Party's 16 mentions (Figure 14). MANA was also the most likely party to name 'workers' and 'unions', terms which imply more working-class agency than the potentially paternalistic emphasis on 'poverty' (ibid). Further, MANA was the most likely party to use explicit terms like 'the rich' or 'capitalists' for dominant groups, indicating a left-wing populism absent elsewhere (Figure 14). Whereas many parties name 'Small Business' (cloaking pro-business policies behind a generic populism), only MANA in 2011 named 'Big Business'. Whereas race "interrupts" the surrounding space of whiteness (Ahmed, 2007, p. 153), class terms like 'rich' and 'poor' interrupt the surrounding reified space of "economics.". According to Kelsey (2015), any departure from neoliberalism must be wholesale rather than piecemeal (p. 125), which partly requires naming the systemic problem: MANA was the only party in my survey to name 'neoliberalism'. These polarising terms interrupt bourgeois universality, highlighting counterposed economic interests rather than identification of bourgeois interests with broader interests.

Although the press in 2011 generally used 'classless' economic terms (Figure 12), coverage of MANA in 2011 reproduced their left-wing populist rhetoric. A Herald headline announced, "Mana fills void as rivals drift to the centre" (Davison, 2011). On November 25 $5^{\text {th }}$, eve of the 2011 election, the front page of the New Zealand Herald announced MANA's party promise: "Tax the rich and feed the poor." Another article, albeit one tucked away as a minor story, explained:

The Mana Party's "parasites on poverty" tour - an extension of leader Hone Harawira's war on poverty - highlighted what he said were major hits on poor people's lives (Tahana, 2011).

As a minor party, MANA contested the dominant neoliberal terms of representation. Instead of dichotomising cultural recognition with economic redistribution, MANA sought an integration of cultural and economic demands (e.g. recognition of Treaty rights, taxing the rich to feed the poor), requiring an appropriate form of political representation: what Nancy Fraser (2005) calls a "three-dimensional politics" (p. 305-306). Harawira (2014) called for an alliance of progressive Pākehā with the Māori Sovereignty movement, harking back to the historical alliance between the Labour Party and the favourable, indicating a need to remain business-friendly.

23 This is even notable considering MANA sent less press releases out than Labour and National, yet MANA made up $82 \%$ of mentions, or 133 out of 156 . 
Ratana Movement. In understanding this discourse, it's worth highlighting the contentious historical context for such an alliance. In her influential work Māori Sovereignty, Donna Awatere (1984) warned of the challenges of bicultural political alliance. Awatere's description of the Pākehā far left was harsh, but resonant:

The left in this country is worse than fragmented. It is dust which unhappily drifts between trade unions and the student unions, subject to every whim of wind and puff of change (p. 50)

Awatere attributed this weakness to the purism and individualism of far leftists (ibid). Conversely, she also noted the emphasis on communal ownership and collective decision-making on the left, traits shared with the Māori sovereignty, movement which may offer a basis for alliance (ibid). MANA attempted at such an alliance. The party articulated working-class constituency in bicultural terms, naming "te pani me te rawakore (the poor and the powerless) as their constituency. Annette Sykes, MANA Candidate for Waiariki, stated in a press release "We are quite clear: we are a party of the left and we are Kaupapa Māori focused" (Sykes, 2011). Similarly, in an interview with the Herald Sykes explained the relationship between working class and Māori constituency:

We're really clear that we are a party for the poor and dispossessed, and unfortunately in my [area] 62 per cent of the unemployed are Māori. But there's also a burgeoning Pākehā poor, and they don't have support (quoted in Davison, 2011).

MANA's electoral strength lay in the Māori electorates, particularly Hone Harawira's Te Tai Tokerau. Prominent Pākehā leftists such as Sue Bradford and John Minto campaigned in General seats, although they campaigned for the Party vote rather than an electorate vote, appealing to a broader Pākehā public. However, they lost by a wide margin, and the Party vote at $0.9 \%$ was marginal. While the party drew on a significant Māori counterpublic in Harawira's electorate, it was unable to forge an alliance with a broader working-class Pākehā counterpublic. After the apparent failure of this strategy in the 2011 election, Hone Harawira sought a new alliance with Pākehā Kim Dotcom in 2014 (to be discussed in the conclusion of Chapter 3). 


\section{Figure 14: Economic terms, party releases 2011}

\begin{tabular}{|c|c|c|c|c|c|c|c|c|c|}
\hline 200: Economic (2011) & ACT & Green & Labour & MANA & Maori & National & NZF & UF & Totel \\
\hline 201: Taxpayer(s) & 2 & 4 & 12 & 5 & 0 & 15 & 5 & 0 & 44 \\
\hline 202: Household & 0 & 0 & 9 & 0 & 0 & 3 & 1 & 0 & 13 \\
\hline 202: Homsowner & 0 & 0 & 5 & 0 & 0 & 1 & 0 & 0 & 7 \\
\hline 203: (First-time) Home Buyer & 0 & 0 & 1 & 0 & 0 & 0 & 0 & 0 & 1 \\
\hline 204: Rent(er) & 0 & 6 & 0 & 5 & 5 & 0 & 0 & 0 & 16 \\
\hline 205: Landlord & 0 & 1 & 4 & 1 & 0 & 0 & 0 & 0 & 6 \\
\hline 206: Homeless & 0 & & 3 & 0 & 1 & 0 & 0 & 0 & 4 \\
\hline 207: Investor & 0 & 1 & 5 & 3 & 0 & 0 & 0 & 0 & 9 \\
\hline 208: Speculator & 0 & 0 & 1 & 2 & 0 & 0 & 3 & 0 & 6 \\
\hline 209: Profit(s) & 0 & 1 & 8 & 4 & 0 & 0 & 6 & 0 & 19 \\
\hline 210: Business & 6 & 8 & 37 & 11 & 2 & 16 & 11 & 0 & 91 \\
\hline 211: Small Business & 4 & 4 & 0 & 0 & 0 & 1 & 1 & 0 & 10 \\
\hline 212: Big Business & 0 & 0 & 0 & 5 & 0 & 0 & 0 & 0 & 5 \\
\hline 213: Entrepreneur & 0 & 0 & 0 & 0 & 0 & 0 & 0 & 0 & 0 \\
\hline 214: Company & 0 & 8 & 8 & 6 & 2 & 11 & 6 & 1 & 42 \\
\hline 215: Corporation & 0 & 1 & 0 & 5 & 0 & 0 & 0 & 0 & 6 \\
\hline 216: Millionaire & 0 & 0 & 0 & 4 & 0 & 0 & 0 & 0 & 4 \\
\hline 217: Billionaire & 0 & 0 & 0 & 0 & 0 & 0 & 0 & 0 & 0 \\
\hline 218: Capitalist & 0 & 0 & 0 & 3 & 0 & 0 & 0 & 0 & 3 \\
\hline 219: Baniker & 0 & 0 & 5 & 1 & 0 & 0 & 3 & 0 & 10 \\
\hline 220: Finance & 0 & 0 & 6 & 5 & 0 & 4 & 1 & 1 & 17 \\
\hline 221: Insurance & 0 & 0 & 62 & 3 & 0 & 9 & 0 & 0 & 74 \\
\hline 222 : Real estate & 0 & 0 & 0 & 0 & 0 & 0 & 0 & 0 & 0 \\
\hline 223: Subcontractor & 0 & 0 & 0 & 0 & 0 & 4 & 0 & 0 & 4 \\
\hline 224: Rich & 0 & 5 & 5 & 24 & 1 & 0 & 1 & 0 & 45 \\
\hline 225: Poor (and Poverty) & 0 & 16 & 6 & 132 & 1 & 0 & 0 & 0 & 156 \\
\hline 226: Inequality & 0 & 2 & 0 & 0 & 0 & 0 & 0 & 0 & 2 \\
\hline 227: (Economic) Class & 0 & 0 & 4 & 1 & 2 & 0 & 3 & 0 & 10 \\
\hline 228: Worker & 0 & 3 & 21 & 37 & 14 & 9 & 4 & 0 & 90 \\
\hline 229: Beneficiary & 0 & 0 & 1 & 35 & 0 & 6 & 0 & 0 & 42 \\
\hline 230: Unemployed & 0 & 0 & 2 & 9 & 0 & 0 & 1 & 0 & 12 \\
\hline 231: Professional & 0 & 0 & 4 & 2 & 0 & 4 & 1 & 1 & 12 \\
\hline 232: Struggler & 0 & 0 & 1 & 0 & 0 & 0 & 0 & 0 & 1 \\
\hline 233: Bludger & 0 & 0 & 0 & 0 & 0 & 0 & 1 & 0 & 1 \\
\hline 234: Union & 0 & 2 & 2 & 13 & 7 & 8 & 0 & 0 & 32 \\
\hline 235: Industry(ies) & 2 & 7 & 25 & 12 & 9 & 25 & 7 & 2 & 91 \\
\hline $236: \operatorname{Job}(s)$ & 0 & 24 & 64 & 32 & 9 & 44 & 14 & 0 & 187 \\
\hline 237: Public private partnership(s) & 0 & 0 & 0 & 0 & 0 & 2 & 0 & 0 & 2 \\
\hline 238: Trans Pacific Partnership Agreement & 0 & 3 & 1 & 14 & 0 & 7 & 1 & 0 & 28 \\
\hline 239: Economy(ic) & 4 & 21 & 77 & 37 & 2 & 99 & 6 & 6 & 248 \\
\hline 240: Market & 0 & 7 & 26 & 9 & 0 & 21 & 2 & 0 & 65 \\
\hline 241: Capitalism & 0 & 0 & 0 & 2 & 0 & & 1 & 0 & 3 \\
\hline
\end{tabular}




\section{Chapter 3: Political convergence and the production of Nonpublics}

Chapter 1 argued that dominant political articulation, and even dominant opposition discourses are shaped by identification with 'New Zealand'. This chapter expands on this point, outlining enforced characteristics of the national political 'centre'. This chapter argues that the 'centre' is in large part defined by exclusion of illegitimate publics and political forces. According to the content analysis, major parties are more likely to name their rivals' potential coalition partners than their own. The chapter will argue that this contributes to a sense of political risk, i.e. that minor party extremists may jeopardise the political centre; the neoliberal capitalist nation-state. Right-wing parties and business voices also tend to portray MMP, which benefits minor parties, as a political risk (NZ Herald, 2011). Similarly, the two major parties each try to claim a centrist public space, both less likely to self-identify as 'left' or 'right' than identify their rivals as such.

Chapter 3 also argues that the press socially construct the political 'centre' in their political reportage. The press are unlikely to use first-person pronouns outside of quotes, and more likely to use thirdperson pronouns, indicating a tendency to stand 'outside' the political process (in keeping with genre conventions which imply 'objectivity'). Conversely, a critical discourse analysis reveals that press tend to reproduce the existing political spectrum, taking cues from official sources. For example, while press cover both minor and major parties, they are more likely to report on 'sensational' minor party figures, reproducing the major party tendency to portray minor parties as political extremists: both the National Party and the major newspapers emphasise sensational figure Kim Dotcom, who backed minor party Internet-Mana, over the politicians in that party.

My critical discourse analysis proceeds to characterise three ways that press and major parties together produce a bounded, legitimised political public. I use the term Disciplined Democracy in reference to a normative limitation on the terms of public participation; social movement activity (such as the Occupy movement) is portrayed as dangerous or unnecessary, while the act of voting is encouraged. Publics therefore are hailed to legitimate existing political forms, rather than contest them. I coin the term Secular Heteronormativity in reference to the tendency of political parties to avoid ${ }^{24}$ explicit references

24 The rare explicit references to sexuality were an exception that proved the role, often discussing sexual liberalism as a political liability (Tapaleao, 2014), a point that the discussion of Secular Heteronormativity will 
to either religion or sexuality, leaving heteronormativity unchallenged, while idealising 'the family' as a normative space outside the public sphere. Finally, the chapter examines the production of an expanding criminalised nonpublic, mainly black and brown (Māori make up $50 \%$ of the prison population), across partisan boundaries. This criminalisation also overlaps with political disenfranchisement, with prisoners deprived of the right to vote, and black and brown subjects generally unlikely to vote (Statistics New Zealand, 2014a).

expand on. While there were other gaps in the nouns surveyed, for example references to disability, this active and explicit disavowal was notable. My survey of nonpublics is not necessarily comprehensive and could be expanded. 


\section{Figure 15: Major party references to minor parties, 2011-2014}

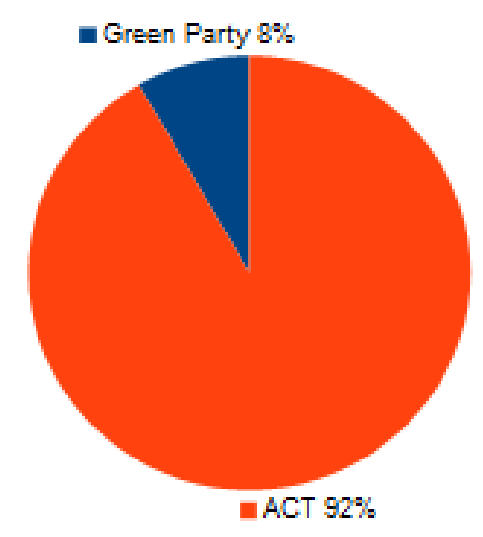

Labour Party

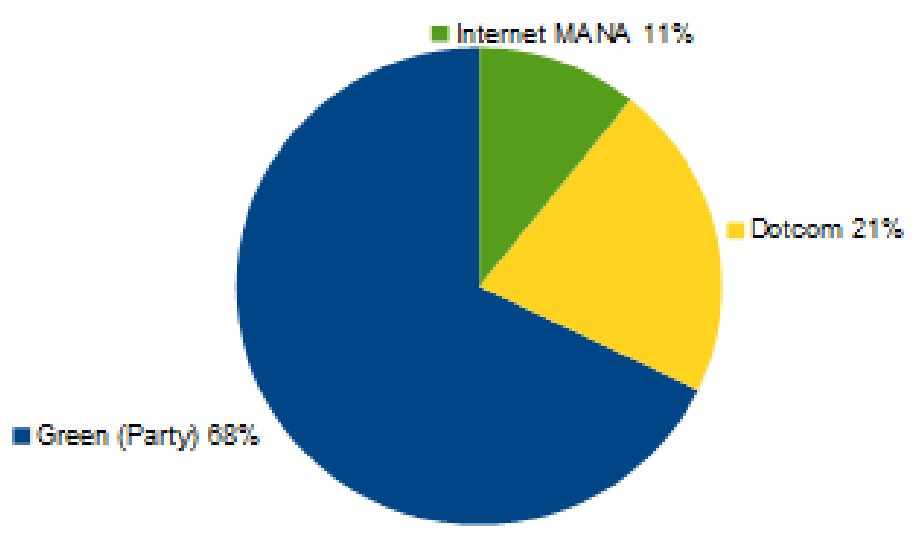

National Party

\section{Major parties vs minor parties}

This chapter is focused on the enforced shape of the political 'centre' in Aotearoa/New Zealand. However as noted in Chapter 1, a positive term can often be understood best through its negation. This section therefore begins with the operation of casting parties out of the 'centre', into political extremities of right and left. Examining major party references to minor parties in the 2011 and 2014 Elections, major parties only tend to name their rivals' potential coalition partners, not their own potential coalition partners (Figure 15). Understanding the reason for this emphasis requires a qualitative examination. In one press release, National MP Bill English warns that a left-wing coalition would be fiscally irresponsible: "Labour, the Greens and Dotcom.... would introduce five new and unnecessary taxes and create a surge of wasteful government spending" (English, 2014). At the outset of the election campaign, Attorney General Chris Finlayson warns about the potentially risky "hydra" of a left coalition:

"Cut off Phil Goff and up shoots David Shearer and Hone Harawira. Saw off David Shearer and up springs David Cunliffe and Laila Harre.”

"The fragmentation on the left hasn't made the hydra weaker," said Mr Finlayson "only more unstable if it can force its way into power again" (Young, 2014a).

National is more likely to name Kim Dotcom than the party or candidates he backed (English, 2014; Joyce, 2014c), a tactic I will return to at the conclusion of this chapter. ACT leader Jamie Whyte refers to a potential left coalition as a "Frankenstein" at the outset of his campaign (Whyte, 2014a). Opponents of MMP in the business community view it as leading to dangerously unstable government (NZ Herald, 
2011). Nationalist, anti-neoliberal minor party leader Winston Peters is particularly seen as a threat to stability (ibid). Press also tend to emphasise sensationalist minor party figures and the associated risks, a point that will be expanded in the section on press coverage of parties. Although minor party ACT benefits from MMP, ACT voters tend to oppose MMP (Miller, 2015, p. 102), arguably because it is seen (by both supporters and opponents) as a curb on the neoliberalism of the major parties. MMP is perceived across the spectrum as offering opportunities to leftist and anti-neoliberal parties.

Labour also tends to name National's potential coalition parties rather than their own, suggesting that National will enter into coalitions with dangerous partisans of the right. Labour MP Grant Robertson warns that the Prime Minister's association with minor party ACT enables neoliberal privatisation: "[Key should] cut ACT adrift. But he won't because he can't. He will need ACT's support to sell our state assets" (Robertson, 2011a). In common, the parties seek to claim the political 'centre' through exclusion of extremist elements.

\section{Figure 16: Political ideology, party releases 2011-2014}

\begin{tabular}{|c|c|c|c|c|c|c|c|c|c|c|}
\hline 1400: Political ideology & ACT & Green & IP & Labour & MANA & Maori & National & NZF & UF & Total \\
\hline 1401: Left & 3 & 0 & 0 & 0 & 9 & 3 & 3 & 0 & 0 & 18 \\
\hline 1402: Social Democratic & 0 & 0 & 0 & 0 & 0 & 0 & 0 & 0 & 0 & 0 \\
\hline 1403: Socialist & 0 & 0 & 0 & 0 & 1 & 0 & 0 & 0 & 0 & 1 \\
\hline 1404: Communist & 0 & 0 & 0 & 0 & 0 & 0 & 0 & 3 & 0 & 3 \\
\hline 1405: Anarchist & 0 & 0 & 0 & 0 & 0 & 0 & 0 & 0 & 0 & 0 \\
\hline 1406: Right & 8 & 0 & 0 & 0 & 17 & 2 & 0 & 0 & 2 & 29 \\
\hline 1407: Neoliberal & 0 & 0 & 0 & 0 & 2 & 0 & 0 & 0 & 0 & 2 \\
\hline 1408: Conservative & 1 & 0 & 0 & 0 & 1 & 0 & 0 & 0 & 0 & 2 \\
\hline 1409: Fascist & 0 & 0 & 0 & 0 & 0 & 0 & 0 & 0 & 0 & 0 \\
\hline
\end{tabular}

\section{Political ideology}

Content analysis of explicit ideological terms finds a similar result: parties are more likely to name their rivals' supposed political ideology ('left' or 'right', 'socialist' or 'neoliberal') than their own (Figure 16). National and Labour generally stay away from language about 'left' and 'right'. National calls their rivals left-wing three times in one press release, warning that the "Left hits "Peak Spending"' (English, 2014). Labour only calls their rivals right-wing once, but neither party self-identifies ideologically. Even MANA, the only party to openly self-identify as 'left-wing' in the content surveyed, names the 'right' nearly twice as much, and is the only party to name 'neoliberalism'. Although this indicates a rare left-wing populism, it also indicates the general preference to label rivals politically rather than self-identifying. Only ACT, a 
firmly neoliberal party, self-identifies as right-wing more often than it accuses its rivals of being left-wing - articulating an explicit strategy of pushing National rightwards (Whyte, 2014a). The only reference to 'communism' comes from right-wing populist party New Zealand First, associating National's privatisation plans with the 'communist government of China', as buyers include Chinese-owned companies (Peters, 2011). Alongside underlining the xenophobia of right-wing populism, this also indicates the sometimes counterintuitive logic of anti-partisanship: Peters associates a right-wing policy with the far-left, both perceived as politically extreme violations of the 'centre'.

With the exception of some minor parties then, the terrain of self-identification is generally 'non-partisan' - any partisanship is regarded as a liability. A cross-partisan consensus upholds the centre as a safe zone. Māori Party leader Tariana Turia articulates this dominant non-partisan ideology the day before the 2011 election, implicitly defending their agreement with the ruling National Party:

Our future wealth and wellbeing is too precious to enter into rhetorical wars of rich against poor; left versus right; tories versus socialists (Turia, 2011)

Turia's term 'our', as with previously covered first-person collective pronouns, stitches together a national coalition, in this case defined by its rejection of political partisanship. Conversely, the only party to refer explicitly to the political 'centre' is minor party ACT: whereas 'left' and 'right' are named and cast out by major parties, the centre is implicitly the unnamed surrounding space. This unnamed surrounding centre-ground is arguably analogous with the rarely-named dominant publics discussed in Chapter 2; Pākehā, men, and capitalists.

\section{Press pronouns}

Chapter 1 discussed how major parties tend to use first-person collective pronouns (we, our), often blurring the line between party and nation. By contrast, press sources only tend to use the first-person collective pronoun when quoting from parties. Outside of quotes, journalists are far more likely to use third person pronouns, specifically 'they', referring to subjects of reportage, particularly voters or politicians:

"a combined 49.2 per cent -- either thought [Jamie Whyte] would make no difference or didn't know or refused to answer, suggesting they simply don't know much about him" (Armstrong, 2014a), "A "no surprises" policy requires departments to tell their ministers when information on 
which they might be questioned is to be released" (Fisher, 2014), "[National] could form a Government with its current support partners, Act, United Future and the Maori Party, assuming they return to Parliament" (Young, 2014b).

This relatively 'neutral', unemotive use of the third-person pronoun positions journalists outside parliamentary processes. This is in keeping with genre conventions, implying objectivity. However, I suggest that the uncritical empiricism of news coverage limits its capacity for political enquiry; they are 'outside' parliament, yet their political horizons are limited to existing political processes and statements. Moreover, the implied objectivity naturalises existing political processes. As Aeron Davis (2010) contends, in defining the 'social construction of politics' model of press-politician relations: "Reporters have become one key component of the social and cultural construction of the political centre and the business of politics itself" (p. 73). Press report on the 'horse race' of parliamentary politics, never offering a philosophical position that challenges the terms of bourgeois democracy itself (a point that will be expanded in the section on 'Disciplined Democracy'), thereby actively 'bounding' the political centre. While the press refer far more often to 'left' and 'right' politics than the parties themselves, this of course refers exclusively to existing parliamentary parties, meaning that the existing political system operates as the limit of political discourse. While the press as a whole may offer a relatively non-partisan, external account of official democratic proceedings, they may also unconsciously collude with the major parties in framing the political 'centre', helping limit the terms of legitimate public participation to existing bourgeois democracy. 
Figure 17: Parties \& leaders, coverage by press 2011

\begin{tabular}{|c|c|}
\hline Parties and leaders & Total \\
\hline National (Party) & 2648 \\
\hline (National Party leader) John Key & 2066 \\
\hline Labour (Party) & 2434 \\
\hline (Labour Party leader) Phil Goff & 925 \\
\hline Green (Party) & 1517 \\
\hline ACT & 905 \\
\hline Maori Party & 356 \\
\hline
\end{tabular}

Figure 18: Parties and leaders, coverage by press 2014

\begin{tabular}{c|c}
\hline Parties \& leaders & Total \\
\hline Labour (Party) & 525 \\
\hline (National Party leader) John Key & 491 \\
\hline National (Party) & 480 \\
\hline Green (Party) & 249 \\
\hline (Labour Party leader) David Cunliffe & 237 \\
\hline (New Zealand First leader) Winston Peters & 176 \\
\hline (Internet Party backer) Kim Dotcom & 165 \\
\hline (Conservative Party leader) Colin Craig & 112 \\
\hline
\end{tabular}

\section{Press coverage of parties}

Drawing out only the most commonly referenced parties, it initially seems the press cover both major and minor parties proportionately to their voter share, with the Greens as the largest minor party (Figures 17, 18). John Key, the Prime Minister, is the most common source in both elections, covered about twice as often as the two successive Labour Party leaders (ibid). However the proportionality becomes less clear when focusing from individual minor party leaders. Minor party leaders are not covered proportionally to their public support: in 2014 , the press was far more likely to cover InternetMana backer Kim Dotcom than party leaders Laila Harre (Internet Party leader) or Hone Harawira (MANA leader). Controversial figures Winston Peters and Colin Craig also crowd out Green Party leaders (Figure 18), despite the Green Party being the third largest party. The press tendency to emphasise 'sensational' minor party figures possibly helps create the impression of extremist threats to the centre. Headlines include "Dotcom's last chance to win credibility" (Armstrong, 2014b), "Gamemakers [Dotcom et al] wreak havoc but leaders battle on" (Trevett, 2014), and "Spectre of resurgent Peters..." (2011). Minor party personalities are portrayed as clowns or as dangerous, compounding the major party narrative of competing threats to the 'centre'. 


\section{Characteristics of the 'centre'}

While apparently disagreeing over which political forces pose a threat to the 'centre', major parties and press both apparently guard the centre against political threats. It may therefore be worth establishing the characteristics of the political 'centre'. While there may be significant overlap between majority opinion and centrist discourse, I contend that 'the centre' is more framed by the "zero level" of discourse, the unstated institutional premise: the capitalist nation-state. According to Roy Morgan polls, $41 \%$ of New Zealanders were concerned about Economic issues in 2014, with the most important Economic issue being 'Poverty / The gap between the rich and the poor' (Roy Morgan, 2014). Although the actually-existing public expresses paramount concern about 'the gap between the rich and the poor', they are hailed not on an economic or class basis, but on a national basis - as New Zealanders. Although the press may retain some critical distance from individual parties and politicians, I will contend they reproduce and actively enforce the limits of the cross-partisan political 'centre': 1) Disciplined Democracy, a bounding of legitimate public participation to voting, 2) Secular Heteronormativity, a discourse that leaves normative sexual \& religous assumptions unchallenged and 3) Criminalisation/Racialisation, the production of a growing criminal nonpublic. 


\section{Disciplined Democracy}

'Disciplined Democracy' is an elite-endorsed form of political representation, in which Discipline predominates over Democracy, actively limiting the terms of participation (see Chapter 0; Mon News, 2010). I define Discipline in Michel Foucault's (1977) sense: an arrangement of bodies in service of power, an enforcement of norms (p. 184). This section will argue that the press limit the terms of Disciplined Democratic participation to engagement with existing institutions, particularly the act of voting, which legitimates the parliamentary system through active consent. Meanwhile, the press chastises or ignores other forms of political activity.

The most explicit articulations of Disciplined Democratic norms emerge in response to non-voting. Three opinion pieces from the Herald and Dominion Post argue for the virtues of existing democratic forms: "Divorcing democracy not an option, despite fatigue" (Bowron, 2014), "A world of reasons to vote" (Dominion Post, 2014), and "It is your decision, don't give it away" (Herald on Sunday, 2014). All three articles note the declining rate of participation, which hit a record low in the 2011 General Election. However, instead of calling for rejuvenated or expanded civic engagement, the editorials simply call for more disciplined participation in existing institutions. After running briefly through a number of possible contributors to the crisis in participation, one editorial states: "Yet finally the responsibility for the low turnout must fall on the non-voters themselves. They are wrong to consider their choice meaningless" (Dominion Post, 2014). For the Dominion Post, non-voters are simply wrong. A Herald editorial also bluntly dismisses reasons given by non-voters to Statistics New Zealand, such as a disbelief that voting would make a difference: "None of these is a good excuse" (Herald on Sunday, 2014). Non-voters' subjective reasons to reject the options are dismissed outright: it is nearly self-evident that any informed citizen in their right mind would want to participate, so these individuals must not be in their right minds. Conversely, while these editors encourage voters to participate, they also place an extensive range of limits on which forms of participation are appropriate, legitimate and permissable. This is perhaps starkest in the contrast between two articles published on November 25 $5^{\text {th }}$ (eve of Election Day), 2011: 


\section{Figure 19: NZ Herald conceptions of democracy}

\section{Remember who owns the election}

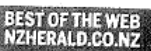

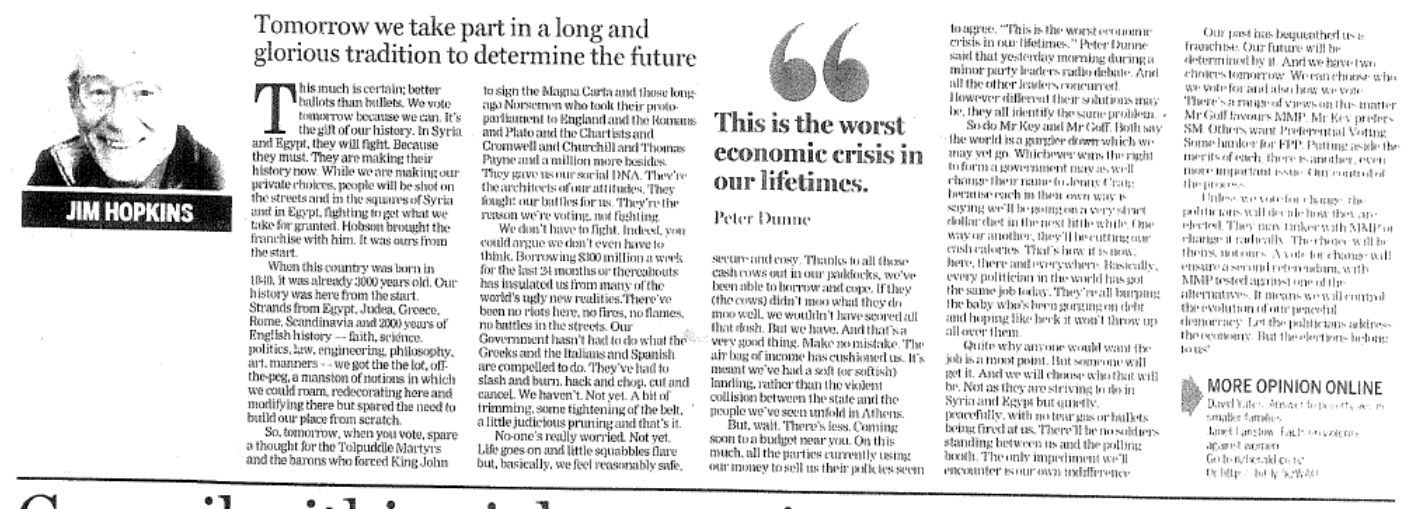

Council within rights to evict Occupy squatters

A more important is at stake than letting protesters stay, writes Patrick Mulligan

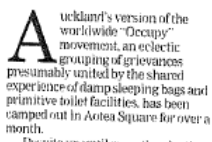
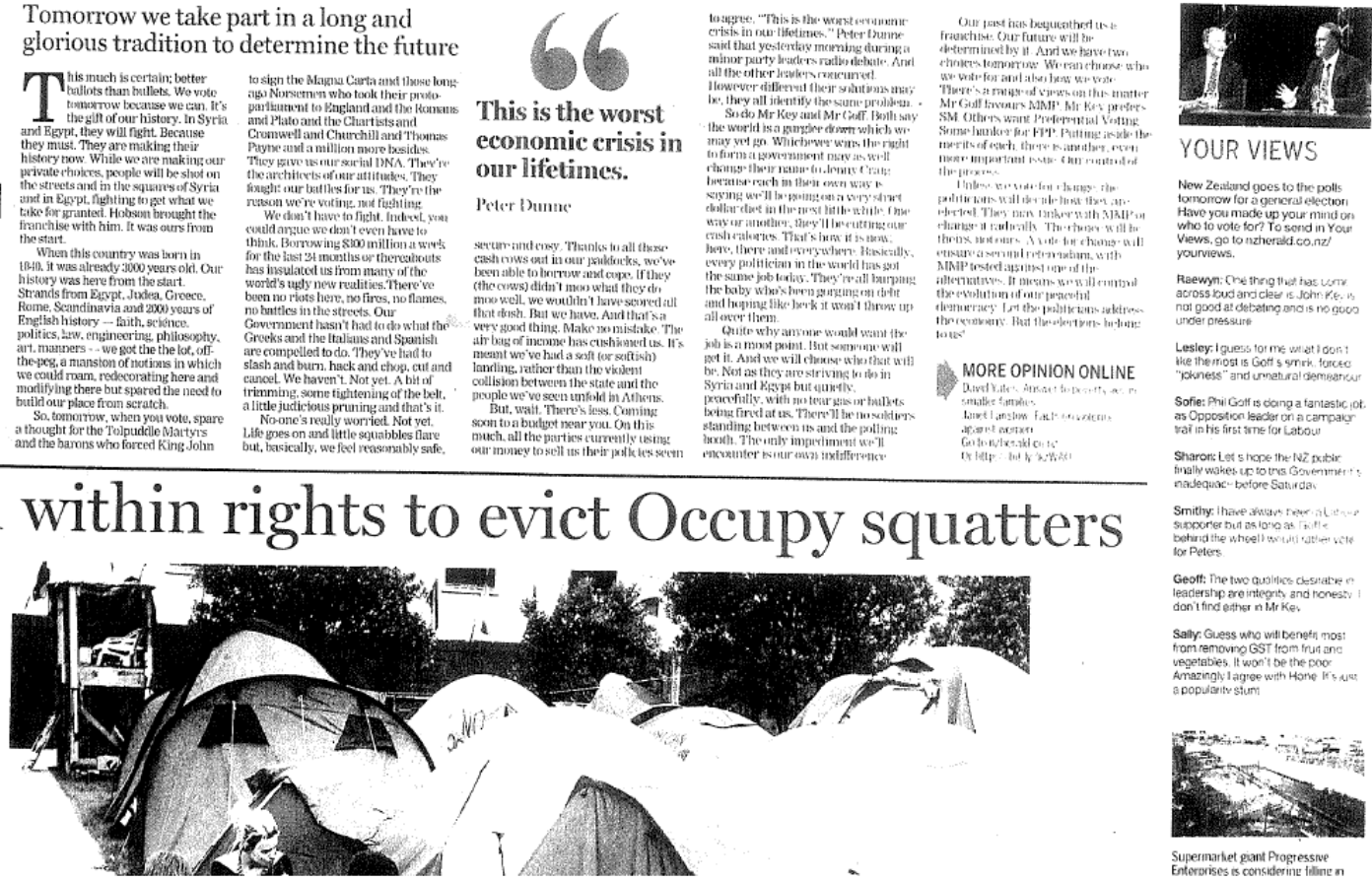

First, the article "Remember who owns the election" (Hopkins, 2011). Contrary to my own prejudices,

Hopkins does not identify the bourgeoisie as 'owning' political processes. Rather, the democratic system was "ours from the start" (ibid). Conversely, this is accompanied with the article "Council within rights to evict Occupy squatters," (Mulligan, 2011), indicating that our democratic rights do not extend to civil disobedience. These articles, and their juxtaposition (Figure 19), draw clear distinctions between Disciplined and Undisciplined political participation.

In fact, the range of disciplined forms of democratic participation are limited to one basic action; casting a ballot. Even the valorisation of democracy movements in the Arab world serves to shore up this limited notion of participation:

In Syria and Egypt, they will fight. Because they must. They are making their own history now... people will be shot in the streets and in the squares of Syria and in Egypt, fighting to get what we take for granted (Hopkins, 2011);

New Zealand is apparently past the need for revolutionary social movements. Hopkins underlines that "Hobson brought the franchise with him" (ibid), apparently not considering the contrast between colonisation and popular revolution as a basis for democracy. Whereas Egyptians are making their 
history, New Zealanders presumably sit at the end of history, in a teleological Eurocentric account. Representative capitalist democracy is the apex of social progress. Meanwhile, attempts to organise a popular movement in Aotearoa/NZ are mocked as "an eclectic grouping of grievances presumably united by the shared experience of damp sleeping bags and primitive toilet facilities" (Mulligan, 2014). For Mulligan, sleeping in an urban tent is not an action befitting a New Zealand citizen; Occupiers are a nonpublic, albeit perhaps a relatively harmless one. The fact that one of Occupy's key issues inequality - overlaps with popular concern merits no mention (ibid). As Butler (2013) contends, longterm occupations of public space assert the political primacy of dispossessed people's material needs:

We cannot presume enclosed and well-fed space of the Polis where all the material needs are somehow being taken care of elsewhere... Rather, we not only have to bring the material urgencies of the body into the square, but make those needs central to the demands of politics (p. 123).

Hopkins notes the significance of the crisis ("This is the worst economic crisis in our lifetimes"), which underlies the material needs asserted by Occupy, but insists that the franchise is all we need. Contrasting examples of social movement activity - the celebrated Egyptian social movement, the derided local social movement - serve as a contrast to the political maturity of the vote.

In contrast to these misguided souls, a number of editorials and opinion pieces hail a kind of Disciplined Democratic citizen, explicitly as a response to the crisis of conventional democracy. A particularly strange opinion piece contends that early voting is somehow an affront to democracy, arguing that voters must keep up with daily coverage and leave their decision until polling day:

Unless you were dead set in your political ways and absolutely sure that nothing would deter you from voting for your political party of choice, surely it would be "unwise" (to use a catchword of this election campaign) to cast your vote early... Keeping up with politics requires real time investment... a commitment to read, listen, watch and process current affairs on a daily basis, even if what you may hear isn't very nice (Bowron, 2014, parentheses in text).

Implicitly, existing press coverage is adequate, and any distaste or disengagement incurred is the problem of the non-voter. Bowron warns that citizens may be abandoning "civil and human rights" (ibid), but makes no effort to explain what's wrong with casting early votes based on policy platform, or party loyalty, or simply due to accessibility requirements. Mysteriously, voters are abandoning the spirit of 
democracy if they don't make a decision on Polling Day, informed by up-to-the-minute reports. For all Bowron's dramatic talk of "taking up arms against a sea of our own troubles" (ibid), her overall prescription apparently expects the voting public to be pliable, non-partisan, law-abiding, centrists who could be swayed based on the latest polls or reports - this 'centrist' figure is cast less as a symptom of a converging political spectrum, than the ideal democratic citizen. Although parties do not show the same interest in non-voters as the press, they do in some ways hail a similar kind of Disciplined Democratic public - as outlined at the beginning of the chapter, major parties tend to cast partisanship as a threat to the centre, apparently calling on a non-partisan public. For the editors and major parties then, the Disciplined Democratic citizen is relatively non-partisan (perhaps frightened by the minor parties), does not participate in social movements, makes their decision based on objective daily updates on parliamentary developments, and most importantly, ticks a box in a voting booth, a legitimation of the existing bourgeois democratic form. 
Figure 20: Gender/sex/sexuality, party releases 2011-2014

\begin{tabular}{|c|c|c|c|c|c|c|c|c|c|c|}
\hline 300: Gender, sex, sexuality & ACT & Green & IP & Labour & MANA & Maori & National & NZF & UF & Total \\
\hline 301: Women & 0 & 6 & 0 & 35 & 1 & 6 & 35 & 0 & 0 & 83 \\
\hline $302:$ Men & 0 & 2 & 0 & 7 & 0 & 3 & 2 & 1 & 0 & 15 \\
\hline $303:$ Intersex & 0 & 0 & 0 & 0 & 0 & 0 & 0 & 0 & 0 & 0 \\
\hline 304: Gender-Diverse & 0 & 0 & 0 & 0 & 0 & 0 & 0 & 0 & 0 & 0 \\
\hline $305:$ Lesbian & 0 & 0 & 0 & 0 & 0 & 0 & 0 & 0 & 0 & 0 \\
\hline $306:$ Gay & 0 & 0 & 0 & 0 & 0 & 0 & 0 & 0 & 0 & 0 \\
\hline $307:$ Bisexual & 0 & 0 & 0 & 0 & 0 & 0 & 0 & 0 & 0 & 0 \\
\hline $308:$ Transgender & 0 & 0 & 0 & 0 & 0 & 0 & 0 & 0 & 0 & 0 \\
\hline $309:$ Cisgender & 0 & 0 & 0 & 0 & 0 & 0 & 0 & 0 & 0 & 0 \\
\hline $310:$ LGT & 0 & 0 & 0 & 0 & 0 & 0 & 0 & 0 & 0 & 0 \\
\hline 311: Qveer & 0 & 0 & 0 & 0 & 0 & 0 & 0 & 0 & 0 & 0 \\
\hline 312: Straight & 0 & 0 & 0 & 0 & 0 & 0 & 0 & 0 & 0 & 0 \\
\hline 313: Heterosexual & 0 & 0 & 0 & 0 & 0 & 0 & 0 & 0 & 0 & 0 \\
\hline
\end{tabular}

Figure 21: Religion, party releases 2011-2014

\begin{tabular}{|c|c|c|c|c|c|c|c|c|c|c|}
\hline 1000: Religious belief \& community & ACT & Green & IP & Labour & MANA & Maori & National & NZF & UF & Total \\
\hline 1001: Muslim & 0 & 0 & 0 & 0 & 0 & 0 & 0 & 0 & 0 & 0 \\
\hline 1002: Christian & 0 & 0 & 0 & 0 & 0 & 0 & 0 & 0 & 0 & 0 \\
\hline 1003: Jewish & 0 & 0 & 0 & 0 & 0 & 0 & 0 & 0 & 0 & 0 \\
\hline 1004: Atheist & 0 & 0 & 0 & 0 & 0 & 0 & 0 & 0 & 0 & 0 \\
\hline 1005: Believer & 0 & 0 & 0 & 0 & 0 & 0 & 0 & 0 & 0 & 0 \\
\hline 1006: Faith (communities) & 0 & 0 & 0 & 0 & 0 & 3 & 1 & 0 & 0 & 4 \\
\hline
\end{tabular}

\section{Secular heteronormativity}

The most striking thing about discussion of sexuality in the 2011-2014 General Elections is that there isn't any; whereas women are named more than men, queer/trans folk are simply not named, let alone naming heterosexuals (Figure 20). Heterosexuals are perhaps analogous with Levi-Strauss' (1963) father at the zero-level of discourse (p. 35). Sexuality and (trans)gender are apparently not considered important election issues by any party, even the parties with progressive policies. Religion is also not mentioned (Figure 21). I call this combined construction of a 'centre', free of troubling challenges to religious ${ }^{25}$ or sexual mores, secular heteronormativity.

Prime Minister John Key typifies the evasive approach to queer politics evinced in secular heteronormativity, justified openly through courting competing publics. When Key voted against the Civil Union Bill in 2004, he said this was due to his constituency's views rather than his own (Trevett, 2012). Before the 2011 election, Key refused to indicate whether he would support same-sex marriage rights at

25 I don't intend here to imply that all religious groups are anti-gay; liberal churches were a key part of the coalition that won marriage equality in Aotearoa/New Zealand (Heather, 2013). However, I suggest that the avoidance of both religion and sexuality as worthwhile election topics indicates an exclusion of contentious topics I have termed 'secular heteronormativity'. 
a forum held by conservative group Family First (ibid). As Family First opposes same-sex marriage rights, Key's reticence may have again been a calculated move in courting a conservative public. Finally, in 2012, Key indicated with a rather passive double-negative that he was "not personally opposed to gay marriage" (ibid). Nationwide polls repeatedly indicated general support for marriage rights, so Key's stance was politically safe in appealing to a broad public. Like all other parties and politicians, Key never referred explicitly to sexuality during the last two weeks of the 2011 and 2014

\section{Figure 22: 3 most common family terms, party releases 2011-2014}

\begin{tabular}{c|c|c|c|c|c|c|c|c|c|c|}
\hline Family terms & ACT & Green & IP & Labour & MANA & Maori & National NZF & UF & Total \\
\hline Child(ren) & 8 & 107 & 1 & 130 & 82 & 16 & 95 & 5 & 0 & 444 \\
\hline (Family(ies) & 1 & 21 & 0 & 100 & 47 & 36 & 67 & 7 & 1 & 280 \\
\hline Kid(s) & 0 & 31 & 0 & 34 & 33 & 2 & 3 & 0 & 0 & 103 \\
\hline
\end{tabular}

General Elections.

Although sexuality is not explicitly mentioned in electoral coverage, regular references to 'children' and 'families' imply a normative and pre-public notion of sexuality. In both elections, parties across the political spectrum invoke 'children' and 'families'. Some parties mention 'children' more often even than 'families', perhaps undermining the thesis that ideal publics are necessarily voters. The Greens in 2014 used 'children' and 'kids' more often even than 'Kiwis' and 'New Zealanders' (although 'New Zealanders' remain their single most common term for the public). We may expect that the ideal 'public' is the free citizen, the voter - hence the castigation of prisoners and non-citizens as nonpublics - however the invocation of the 'child' complicates this. Children do not vote. The idealised 'child' implies a kind of preexisting innocent space where publics are formed, from whence publics enter into discourse, the nonpoliticised space of 'the family.' As Berlant and Warner contend, the heterosexual family is "prepolitical", located outside the public sphere (p. 553). Families both incubate future voters, and more crucially, members of 'the public' are assumed to have children. The invocation of children hails an assumed parental audience, including an extended audience who may not be parents but are assumed to care about 'our children'. Assumed parental publics seek to guard children against threats, and vote for the parties who will combat threats to their children. These threats are a moving target; the threat of poverty for left-populists (Bradford, 2011), of illness for major parties (Ryall, 2011), of homosexuality for conservative lobby groups (Family First, 2014). Whatever the specific threat, the concern for children crosses partisan boundaries, as a 'floating signifier' which all political actors seek to appropriate. Sociologist Joel Best (1990) suggests that as concerns about the future have increased in the risk 
society of neoliberalism, a specific focus on the Child as "innocent" has also increased (p. 171-172). Queer theorist Lee Edelman (2004) contends that the Child is "the fetishistic fixation of heteronormativity" (p. 21). Of Labour's 55 references to 'poverty' in 2011-2014, 30 refer specifically to 'child poverty'. More dramatically, 59 out of 61 Green Party references to poverty in 2011-2014 specify child poverty (National makes no references to 'poverty' in the content analysed). Journalist Bryan Bruce's avowedly 'apolitical' documentary on child poverty also received widespread attention in the lead-up to the 2011 election (TV3, n.d.; APNZ, 2011; Mullord, 2011). While this may reflect a genuine social crisis and the concerted work of groups like Child Poverty Action Group, the single-minded focus on the innocence of child victims may also imply a distinction between deserving and undeserving poor. While no child could deserve poverty, adults can be said to bring it on themselves. As the deserving/undeserving framework is a key ideological justification of poverty (Dorey, 2010), this approach arguably cedes ground to the right, attempting to avoid political-economic conflict through reference to the imagined pre-political common ground of 'the family'.

The innocence of children gives way to the threat posed by youth, who become a nonpublic that must be normalised. Around $40 \%$ of $18-25$ year olds in Aotearoa/New Zealand do not vote, compared with 5$6 \%$ of over 65 s (Statistics New Zealand, 2014a). There may be a range of factors influencing this this; youth unemployment, housing precarity affecting eligibility for enrolment, political failure to address youth concerns, or lack of interest. Applying a Foucauldian analysis to the treatment of youth in the Canadian criminal justice system, Eisler (2007) argues that rather than focusing on youths' individual pathology, we must consider how the system produces "classifications of normal and abnormal, healthy and unhealthy, and acceptable versus unacceptable" (p. 103). While minor parties refer to youth rarely if at all, National and Labour refer to youth 25 times and 32 times respectively in 2011 and 2014. For both parties, the term 'youth' always occurs in combination with terms like 'drugs', 'prison', 'offenders' - a consistent association between youth and criminality. National Party press releases express concern about 'youth offenders', whose behaviour can be addressed through youth courts, youth prisons, targeted healthcare, and Youth Guarantee schemes in employment (te Heuheu, 2011). Labour focuses more than National on employment opportunities for youth, most often using the the slogan "[u]se youth unemployment to fill the skills gap". While this is a different emphasis to National, youth still appear as a problem that must be fixed, and both parties suggest employment as a fix. As Eisler (2007) notes, the 
criminal justice system works in combination with other institutions to normalise youth (p. 114). Youth by definition are always dangerous and endangered, in contrast to children who are always innocent and endangered, or adults who may actually be productive citizens. Youth must be normalised, fixed, reintegrated into capitalist society, so they can become healthy productive adults. This discourse is about the youth problem, addressing adults rather than youth as an active public. Youth are thereby produced as a nonpublic, albeit one 'we' (implicitly adults) should be concerned about. Youth in this discourse confront a fork; to continue as a nonpublic, becoming criminalised adults after passing through youth courts; or to join the ranks of the respectable, productive public. Whereas children are always-already integrated into the prepolitical family, youth partially depart from this ideal into a dangerous 'nonpublic' space, and must be re-normalised.

Berlant and Warner (1998) contend that central to dominant political articulations of 'the public' is "something that cannot speak its name, though its signature is everywhere: national heterosexuality" ( $p$. 548) This theoretical context is worth establishing before proceeding to a critical discourse analysis of selected articles. Although Aotearoa/New Zealand has granted formal equality to same-sex couples, the assumed "notion of privacy" (p. 547) in invocations of 'the family' cloaks the "memory" of sexual life necessary to challenging heteronormativity (p. 562). Explicit discussion of sexual and intimate relationships is absent, leaving dominant forms uncontested (while some may note that this is not what you'd expect in an election campaign, queer theorists and activists would respond that this relegation of sexuality outside the democratic 'public sphere' is part of the problem). As queer theorist Michael Warner (1993) underlines in coining the term, "heteronormativity can be overcome only by actively imagining a necessarily and desirably queer world" (xvi), in contrast to political articulations which leave normative assumptions unchallenged. Formal equality is also compatible with what Duggan (2002) terms 'homonormativity', an extension of heteronormative norms to same-sex relationships:

[homonormativity is] a politics that does not contest dominant heteronormative assumptions and institutions but upholds and sustains them while promising the possibility of a demobilized gay constituency and privatized, depoliticized gay culture anchored in domesticity and consumption (p. 179).

While the recognition of same-sex couples may be a progressive step, the extension of formal rights assumes a certain kind of romantic relationship and a certain kind of queer subject. A young single, 
urban person who is experimenting with intimate relationships, and has not settled into a monogamous relationship, is constituted outside the zone of familial comfort and the associated economic protections. Queer urban subjects are nonpublics in this discourse, unnamed as a constituency. By contrast, 'the child', as a venerated member of 'the family', is named and defended by all political players in appealing to an assumed heteronormative public.

Given this assumed heteronormative public, queer rights are perceived as a political liability. In a New Zealand Herald article on Pasifika voters, gay rights is openly discussed as a liability for politicians:

People still upset about Labour's gay marriage bill were considering giving their votes to the Conservatives and those with more radical views were now thinking of giving Internet Mana or the Greens the tick (Tapaleao, 2014).

In this extract, Pasifika voters who express homophobic and conservative views are assumed by media to represent the community as a whole. A 2011 Research New Zealand poll actually found that Māori and Pasifika participants were slightly more likely than Pakeha to support same-sex marriage rights; $66 \%$ of Māori-Pasifika participants in contrast to $61 \%$ of Pakeha (Research New Zealand, 2011). However, Pasifika and gay publics are discursively counterposed with each other. Common ground among oppressed groups is foreclosed (the term fa'afafine, referring to a Pasifika form of Third Gender, does not show up in the content), leaving politicians as the necessary mediators between competing publics. Politicians are therefore portrayed as walking a tightrope, between a homophobic constituency and a minority granted some rights in a secular regime. I call this negotiation between imagined publics secular heteronormativity: although the regime generally does not endorse open homophobia, political 'leaders' practice a calculated silence on both religious conservatism and the rights of gender/sexual minorities, in an attempt to shore up competing constituencies.

While sexuality is very rarely mentioned in the content under analysis, a 2012 controversy around Key was an exception that perhaps explains the rule. Appearing on a radio programme, The Farming Show, Key used a homophobic slur in ribbing host Jamie Mackay:

You're munted mate, you're never going to make it. You've got that gay red top on there (Stuff, 2012).

References to clothing as 'gay' call mainstream masculinity into question; in this case John Key jokingly 
continued that Mackay's clothing called his credentials as a "centre-right, interested community member" into question (ibid). Given that lesbian, gay and bisexual ${ }^{26}$ youth in Aotearoa/NZ are five times more likely than their straight peers to attempt suicide (Lucassen et al, 2012), many queer activists do not take the use of schoolyard insults like 'gay' lightly. Activists as geographically distant as lan McKellan rebuked Key (Chapman, 2012). National Party leaks indicate that leaders' public appearances tend to follow the careful prescriptions of PR advisers (Hager, 2006), so it's unlikely this was an accidental slip. Rather, Key's appearance on The Farming Show was a conscious attempt to court a conservative public. Although the specific term 'gay' may not have been planned, it fits this broader discursive strategy of courting conservatives, in this case through use of a term that gay activists have underlined as doing harm.

In fact, even defence of Key's action indicates that it was a conscious effort to court a conservative public. An opinion piece by Karl du Fresne indicates the sneering attitude that enforcers of secular heteronormativity hold towards gay activists, with the headline "Gays being precious over PM's 'slur'" (du Fresne, 2012). Du Fresne cites "New Zealanders", the key cross-partisan public, as a presumably heterosexual and conservative audience:

I suspect most New Zealanders would have viewed the fuss with an air of worldly resignation. They have become well-accustomed to minority groups rearing up on their hind legs at every imagined slight (du Fresne, 2012).

Notably, queers apparently aren't the only "minority group" to alienate "New Zealanders", indicating that the term for a national public refers implicitly to dominant groups. Du Fresne also endorses and justifies the interpretation that Key is attempting to balance constituencies:

[He] was merely making an attempt to sound blokey in order to connect with that radio programme's audience.

How quickly his critics forget that he has ingratiated himself with gay men, too - for example, by speaking at the Big Gay Out rally in Auckland last February and posing for photographs with transvestites.

26 Transgender youth were not explicitly covered in this survey. 
That's what politicians do: pander to whichever group they happen to be addressing at the time (ibid).

While this argument coincides with my assertions about courtship of competing publics, du Fresne's comments leave this political cynicism naturalised and unchallenged. Du Fresne makes no attempt to claim that Key's slur was an accidental or thoughtless comment. He contends that it was a conscious attempt to court a public, and is therefore justified. For du Fresne, the job of a politician is to court audiences, not to stand on consistent programme or principles - in late politician Tony Benn's terms, politicians should be 'weathercocks' rather than 'signposts', prioritising popularity over principles (Farndale, 2009). A 'casual' slur on talk radio may serve to attract conservative audiences otherwise alienated by prevailing liberal attitudes, and is therefore appropriate. Du Fresne also further provokes the implied queer audience by using the term 'transvestite', a dated and medicalising term that has largely been superceded by 'drag queen'. This implies an ambivalent relationship between queers and the secular heteronormative regime; we (queers) will not be executed or imprisoned, we will be legally tolerated, even outrageous performances of Outness are tolerable in dedicated venues following a welladvertised timetable, so long as we tolerate the occasional public slur, for the 'Kiwi blokes' in the audience. Secular heteronormativity constructs the national 'centre' as a space excluding challenges to sexual and gender norms. Secular heterormativity is a liberal regime in which some forms of formal equality are conceded, yet 'the family' remains unquestioned as the pre-political site of nourishment, and queer militancy risks alienating 'the (heterosexual) public'. 


\section{Criminalisation/racialisation}

This research project has often focused on common political discourses that transcend partisan boundaries. The carceral state (Foucault, 1977), or the specific tactic of 'penal populism' (Pratt, 2007), is one such cross-partisan project. In terms of my thesis, the prison system produces a growing nonpublic, disavowed by the political establishment, defining the national public by negation. Although incarceration has fostered this barrier since its inception, the neoliberal era has seen an intensified form known as "mass incarceration" (Alexander, 2010). With the advent of 'colourblind' discourse in the US, mass incarceration provides an alibi for the deprivation of citizenship rights to (primarily) black and brown subjects, who form a growing reserve army of labour (Alexander, 2010; Smith, 2014a). Similarly in Aotearoa/New Zealand, 'bicultural' discourse masks a growth of Māori imprisonment, with Māori making up around $50 \%$ of prisoners compared to $13 \%$ of the general combination (Smith, 2014a). This production of racialised subjects as a nonpublic also extends to political disenfranchisement, with prisoners unable to vote and non-voters likely to be Māori or Pasifika (Statistics New Zealand, 2014a). To facilitate the neoliberal combination of cultural recognition with upward redistribution of wealth, the disciplinary apparatus has expanded exponentially. Smith's (2014a) account explains how the ruling class benefits from mass incarceration in Aotearoa/NZ: my account will consider how the ruling class seeks consent for this project. Criminologist John Pratt notes how public support for 'penal populism' has counterintuitively grown during a period with a declining crime rate (p. 36). Pratt suggests that penal populism offers a sense of "social cohesion" in a period marked by increasing economic precarity and decreasing participation in public institutions (p. 37-65). Coercion and consent, key elements of hegemonic state power, work in tandem here: consent of the lawful public is sought through the application of coercion.

Law and order rhetoric crosses partisan boundaries, with all parties competing to prove their toughness on crime. On the eve of the 2011 election, Labour appeal to the state's monopoly of violence as a function undermined by the cost-cutting ruling party:

They think if they sling enough mud, they will be able to shift attention from the fact they've been caught out cutting police recruits. But Kiwis won't be fooled (Robertson, 2011b; emphasis mine). 
During the 2014 General Election campaign, reactions to a National Party announcement about "working prisons" underlined the cross-partisan enthusiasm for incarceration. Press coverage was unambiguous that prisoners would be paid a tiny fraction of the minimum wage: "Inmates can earn a small income -- about 60c an hour -- inside jails" (Davison, 2014). Spokespeople for the Greens and Labour endorsed "working prisons" in principle (ibid). A Green spokesperson supported the project "as long as the cheaper labour did not undercut the private sector outside," a concern premised only on the rights of free labourers (ibid). No party expressed any concern about the employment rights of prison workers. Prisoners directed to work by the Department of Corrections are not considered employees (Morgan v Attorney General, 1965; cited in NPIP, 2016). Prison workers are therefore deprived of the basic rights ensured by the Employment Relations Act 2000 and Minimum Wage Act 1993, along with the deprivation of other fundamental rights of citizenship (NPIP, 2016, p. 86). In other words, the conditions of prison workers would merit the term 'slavery' if the workers were not already designated 'criminals'.

Angela Davis (2003) underlines how, paradoxically, the notion of depriving citizenship rights (like the minimum wage) requires the elaboration of universal rights as a political principle, beginning with the French and US revolutions (p. 43-44). The notion of depriving rights as a punishment stems from the elaboration of rights, where previously they were not assumed (ibid). While some liberal reformers sincerely consider prison labour a form of rehabilitation, rather than punishment, there is no $a$ priori reason why rehabilitation should involve labour exploitation without the full rights of a citizen. Rather, this requires that people are designated 'prisoners', a nonpublic. This recognition (or nonrecognition) of prisoners as a nonpublic is universally accepted ${ }^{27}$ in dominant political discourse. A press release from New Zealand First asserted that "Working prisons are not a breakthrough innovation - it's simply common sense" (Lole-Taylor, 2014; emphasis mine). This would appear to match Gramsci's notion of 'common sense' as the "average opinion of a particular society" (2011a, p. 173). As Foucault underlines, punishment must appear natural, above politics (1977, p. 106). Not only was National's policy supported by the 'Left', but parties further to the Right suggested it was too generous: "Two of the party's potential coalition partners, Act and the Conservatives, want the Government to take a tougher approach to criminals" (Davison, 2014). To the degree that parties were in competition, this competition 
was less over divergent political programmes than assuring the assumed public that parties supported the "common sense" of expanding the carceral state. No party wanted to be seen as 'soft on crime'. Further, media coverage served to emphasise this political convergence, with the headline "Left backs National's plan for 'working prisons'" (Davison, 2014).

The cross-partisan consensus hails a law-abiding citizen, who wishes to see criminals punished, or more charitably rehabilitated through slavery. This cross-partisan support extends not only across the parliamentary 'Right' and 'Left,' but to liberal NGOs and academics working in the area. John Pratt, a criminologist focusing on 'penal populism' in NZ and internationally, endorses prison labour as a rehabilitative measure. JustSpeak, an NGO seeking prison reform, proudly announce that their pamphlets are "Printed by Rimutaka Prison printing press" (JustSpeak, 2014). Prison abolitionists have criticised this as endorsement of "slave labour" by the NGO (McRae, 2014). To understand how JustSpeak's reform programme could involve endorsing slavery, it is worth underlining the specific historic relationship between prison 'reform' and the carceral state. Foucault (1977) contends that prison reform "is virtually contemporary with the prison itself: it constitutes, as it were, its programme" (p. 36, cited in Davis, 2003, p. 40). Foucault outlines the 'programme' of prison reform, which has been fairly continuous from the inception of the carceral state to this day:

[N]ot to punish less, but to punish better; to punish with an attenuated severity perhaps, but in order to punish with more universality and necessity; to insert the power to punish more deeply into the social body (p. 82)

Reformers enshrine the production of a criminal nonpublic as a necessary evil, meaning that carceral logic is only further embedded by reformist discourse. The prisoner is the "common enemy" of society (p. 90), the ultimate nonpublic. Whereas foreigners may become citizens, and unemployed people may become employed, the prisoner is defined by the loss of citizenship rights. Even on release, access to housing, employment and other basic rights is limited by having a criminal record (Alexander, 2010; Smith, 2014a). The legitimate, law-abiding public has its position apparently secured through the creation of a growing class of unpersons. Conversely, the punishment also serves as a threat. Foucault notes the "lateral" impacts of punishment: "punishment is directed above all at others, at all the potentially guilty" (p. 108). The boundaries of the public are maintained through the threat of the nonpublic. The notion of securing publics against criminality also offers perceived security in the 'risk 
society' of neoliberalism (Pratt, 2007). As all parties and press converge around this production of a nonpublic, it is expressed as a universal 'common sense'.

\section{Dotcom as a criminal threat}

This chapter has previously discussed how parties tended to name their rivals' potential coalition parties and ideologies, rather than their own. In 2014, National perfected this strategy by referring to 'Dotcom', seen as a threat to the centre, more often than Internet Mana, the party he backed. In separate press releases from separate MPs, National referred to their rivals as "Labour, The Greens and Dotcom" (Joyce, 2014c; English, 2014). This is an interesting turn of phrase, as it mixes categories: two party names, and the financial backer of a third party who was not even standing as a candidate.

National's strategy worked out ${ }^{28}$ in the mainstream media. Dotcom received more coverage in 2014 than Laila Harre, Hone Harawira, or their respective parties (Figure 18). In press releases, Hone Harawira still uses the left-populist rhetoric he had used in 2011:

The National government and its attack bloggers refer to the working poor as scum, bludgers and ferals, but it's clear the real problem is with the top $1 \%$ of income earners who get all the benefits of taxpayer funded facilities and services but don't pull their weight paying for them (Harawira, 2014)

This release was not picked up by the press, which was typical of 2014 Internet-Mana coverage. Whereas in 2011 the press reported directly on Harawira's leftist rhetoric (see Chapter 2), in 2014 MANA's left-populism was eclipsed by the ambiguous politics of Kim Dotcom. This alliance was controversial on both ends of the political spectrum; 1) for the socialist militant, Harawira was made a traitor by his association with Dotcom (Peters, 2014; Ferguson, 2014; Gregory, 2014); 2) for the bourgeoisie, I suggest, Dotcom was made a traitor by his presumed criminality and his alliance with leftist and Māori militants. It is the second half of this equation - the demonisation of Dotcom by his fellow billionaires and by bourgeois politicians - that this analysis focuses on.

28 It is worth noting here that the relationship between party press releases and newspaper coverage was not direct. While the press used similar discourse to the major parties, as noted in the Dotcom example, this often took the form of original writing by journalists or quotes from politicians (which closely matched the discourse of press releases). Therefore while press did not simply reproduce the content of press releases, major parties had an agenda setting role. 
Dotcom's Pākehā status was highlighted more than any other Pākehā participating in the 2011-2014 General Elections. In fact, no other individual Pākehā was named as such in 2014, with the Māori Party and MANA making brief references to Pākehā as a broader class of people, but not singling Pākehā out (similarly in 2011, MANA candidates Sue Bradford and John Minto were singled out as Pākehā). ACT's Jamie Whyte described the Internet MANA coalition thusly: "Who are working as volunteers - the Maori $^{29}$, and who are getting paid exorbitant money - the Pakeha" (Whyte, 2014b). This appears to be the only time ACT express concern about Pākehā materially benefiting from exploitation of Māori. Similarly, other commentators identify Dotcom as a multimillionaire or billionaire, not terms used anywhere else in election campaigns: "[Harawira's rival candidate Kelvin Davis questioned] the relationship multimillionaire Kim Dotcom had struck up with the Mana Party" (Ihaka, 2014), "The worse thing about all these allegations is that they have all come from one source, the Internet Mana Party backed by the billionaire hacker" (Flavell, 2014). Accusations came not only from rival parties, but bourgeois commentators such as John Barnett, the CEO of South Pacific Pictures, who stood to benefit from copyright laws Dotcom violated: "[Dotcom is] a man with a criminal record who pays little or no tax in New Zealand and uses ill gotten gains to promote a personal agenda designed to influence legal outcomes." Dotcom was marked as foreign, criminal, and rich. ACT's Jamie Whyte also referred to Dotcom often as a "German fraudster" (Whyte, 2014b; 2014c; 2014d); a formulation combining foreignness and criminality. National Party MP Maggie Barry reportedly told Internet Party leader Laila Harre to "stop sucking on the German's purse" (Bowron, 2014). An opinion piece derisively referred to him as a "large German" (Pagani, 2014). Critics failed to explain why a German (or a large person) should be less credible than any other tau iwi (non-Māori/foreigner). It's hard to avoid a conclusion that this emphasis harks back to New Zealand's role in the first two world wars, with Germans depicted as inherently threatening to 'our democracy'. Dotcom was depicted as a threat to the centre, a foreign and illegitimate influence on public discourse.

Although dominant political actors repeatedly name Dotcom as a 'Pākehā' and a 'billionaire', this cannot be the crux of their objection - as previously covered, Pākehā billionaires fund both major parties, remaining largely unnamed in political discourse. Rather, Dotcom is marked and separated from the 
bourgeoisie first by criminalisation, and second by alliance with a left-wing indigenous movement. Harawira appears a hypocrite ${ }^{30}$ for aligning with a bourgeois pakeha - Dotcom appears as a traitor to the bourgeoisie, eclipsing Harawira and the MANA Movement. Through this betrayal of the bourgeois nation-state, Dotcom emerges as a kind of warped mirror of international capital; a transnational archcriminal, a leader of a Nonpublic ${ }^{31}$, a representative of risk society, a threat to the nation, and perhaps worst of all, a German. In an ironic twist on populist themes, this party with a widely demonised 'foreign' capitalist backer also campaigned against 'foreign' capitalist ownership alongside other opposition parties.

As a minor party, Internet-Mana used Dotcom's prominent criminalisation to highlight the broader issue of surveillance. On the Internet Mana Road Trip, Annette Sykes highlighted Dotcom's criminalisation as a point in his favour, in terms recalling the surveillance and criminalisation of Tuhoe (who Sykes has defended in court):

Families are destroyed when the cops come into your house with their guns. That's what happened to Kim Dotcom. I must say that was the only thing about him, I don't care about his money, that was the only thing that I really admired him for. Because when it happened he stood up for him and his kids and his family (Anderson, 2014).

Sykes advocated a cross-class alliance between Dotcom and a Māori counterpublic, on the basis of common experiences of surveillance and criminalisation. Given that Hone lost his Māori electorate seat in the 2014, it seems this attempted alliance around the surveillance issue failed. However, the NZ Herald referred to 'surveillance' 53 times in their coverage of the 2014 election, in contrast to 4 times in their 2011 coverage. All of these references occurred in articles dealing with the Internet Party's Moment of Truth event, designed to highlight mass surveillance. Although Dotcom eclipsed Mana's messages concerning inequality, this minor party was still able to influence mass media discourse. highlighting mass surveillance in an attempt to hail a subaltern counterpublic (apparently unsuccessfully, as MANA lost its only seat in 2014).

30 Harawira lost his seat, meaning that MANA lost its sole representative in parliament.

31 One moral panic during the Internet Mana campaign centred on teenagers chanting "Fuck John Key" at a Dotcom event, clearly transgressing limits of Disciplined Democracy. 


\section{Conclusion}

A context of "democratic deficit" (Beetham 2002; Grey and Sedgwick 2013), or declining public participation in politics, poses challenges for theorists with a normative interest in popular agency. This project asked the questions, how did political parties named the 'public' (or publics) in the 2011 and 2014 Aotearoa / New Zealand General Elections? Secondly, what degree of representation these invocations of 'the public' find in the national press? As a possible answer, reseach sought to test the hypothesis that dominant cross-partisan electoral discourses defined the 'public' in terms of dual identification with productive work and capital, in opposition to named subaltern nonpublics. My analysis began with a content analysis of parliamentary party press releases and newspaper coverage in the last two weeks of the 2011 and 2014 General Election. My analysis identified the importance of the nationstate to dominant identification, with 'New Zealander' by far the most commonly hailed public, a more common site of identification than any explicit economic identification. I would therefore reconceptualise the initial formulation to say that dominant cross-partisan electoral discourses defined the 'public' in terms of identification with the bourgeois nation-state, in opposition to named subaltern nonpublics. As the bourgeois nation state is a cross-class coalition, this partially confirms the initial hypothesis, albeit in a refined form. My distinction between left-wing and right-wing populism, with the latter concept hailing the nation in opposition to institutional elites, helped analyse the divergent and common ground between dominant Government discourses and dominant Opposition discourses. Both articulations fail to challenge the dominance of capital, whether through identifying the interests of the nation with the interests of international capital in National's case, or diverting attention from capital towards 'foreigners', including migrants, in Labour's case. Having identified a central focus (the nation) through content analysis, my critical discourse analysis then characterised how this nationalist identification was constituted, the commonalities and divergences across parties, and the challenges that emerged. MANA briefly emerged as a left-wing challenger, hailing a subaltern counterpublic - te pani me te rawakore (the poor and powerless). The mainstream press tended to reproduce the existing parliamentary spectrum, and portrayed minor parties in a sensationalist fashion, but also reported on the policy concerns raised by minor parties. 


\section{Dominant discourse}

With the exception of MANA and the Māori Party, 'New Zealander' was the most commonly named public across all parties. The first chapter considered how the two major parties, National and Labour, invoked a national public. The analysis focused first on pronouns, as an indicator of identity and allegiance. Ruling party National strongly preferred first-person collective pronouns - 'we' or 'our' - at $83 \%$ of their pronoun uses, the most likely party to use first-person collective (Figure 6). My analysis suggested that the major party 'we' stands for the party representing the nation. Critical discourse analysis therefore examined how each party sought to constitute this representative link.

The comparison considered how each party constitutes the national 'we', before critically examining these discourses. The analysis examined the converse terms for 'New Zealander', as a way of understanding the discursive limits of 'New Zealand'. The ruling National Party was the most likely party to use the term 'international', while the opposition Labour Party was most likely to use the term 'foreign(er)' (Figure 8). The National Party tended to use a confident executive 'we', singularly and competently mediating between social interests, in service of the nation. I considered this discourse through Laclau's 'institutionalism', which for Laclau is the opposite of 'populism' (1985, 2005a, 2005b). National Party discourse tended to emphasise social mobility over directly addressing poverty. In a neoliberal inflection of institutionalist discourse, the National Party 'we' offered a managerial voice, elevating private sector management principles to a general ideology (Klikauer, 2013). The National Party's institutional discourse can also be characterised as bourgeois internationalist, promoting integration with neoliberal international institutions. For the National Party, participation in the international neoliberal regime was best for New Zealand business, and therefore all New Zealanders; a neoliberal inflection of national discourse.

This analysis also considered whether the main opposition party challenged the dominant discourse. The last two years have seen the re-emergence of significant social democratic/left-reformist movements in the Anglo-European world; behind Syriza in Greece, Bernie Sanders in the USA, and Jeremy Corbyn in the UK (Dean, 2016, p. 1-25). Each of these countries has also seen the growth of right-wing populist movements; Golden Dawn (Greece), Donald Trump (USA), and UKIP (UK). My analysis suggested that a major left alternative has not emerged in Aotearoa/NZ. My framework defined 
Right-Wing Populism in terms of polarisation between nation and elite, and Left-Wing Populism through polarisation between subaltern and elite (Figure 4). This distinction between left- and right-wing populism helped identify the degree to which nationalist articulation contested or enforced existing political structures. This distinction is not adequately considered in Laclau's (2005a) analysis of populism (Jovanovski, 2016; Gurhanli, 2013). Labour was the most likely party to use the term 'foreigner' negatively, using the term 35 times, failing to distinguish between international capital and migrant labour, and ignoring the role of local capital (Figure 8). This term polarised the political terrain along nationalist lines. Although this nationalist discourse called aspects of National's neoliberal 'bourgeois internationalism' into question, it did not contest the structural elements at the root of the neoliberal project. Rather than identifying the capitalist basis of the housing crisis (Harvey, 2014), New Zealand Labour scapegoated migrants with 'Chinese surnames' (Chapter 1). Therefore neither major party addressed the roots of the housing crisis, instead encouraging publics to identify with capital.

I suggest that these competing Institutionalist/Populist articulations are less differences of programmatic principle, than differences between Government (institutionalist) and Opposition (populist) discourses. While in government from 1999-2008, Labour began negotiating the Trans-Pacific Partnership Agreement, and generally "served to embed neoliberalism more deeply" (Kelsey, 2016, p. 123-124). By contrast, over that period, the National Party resorted to anti-Māori populism (Hager, 2006), explicitly discussing this approach as a 'populist' electoral tactic in leaked private emails (ibid). When race-baiting failed, National spoke of an oppressed 'underclass' ignored by the Labour government, again a populist term (Berry, 2007). A content analysis of Key's speeches since 2007, published in The Dominion Post, found that he referred to "climate change" 121 times in 2007, and only 3 times in the last three years, indicating a shift after his election (Mitchell, 2015). This comparison suggests these discourses are more a function of Opposition and Government roles than permanent features of the respective parties. Whereas Government may benefit from the 'Institutionalist' discourse implying that differences are being competently mediated, Opposition may seek a populist polarisation demanding a change of government. However, my quantitative analysis only covers a period with Labour in opposition. A more longtitudinal content analysis could more firmly establish to what degree party discourses are permanent features of the respective parties, or shaped by their shifting positions in parliamentary contest. In any case, both Institutional discourse and Right-Wing Populism invoke a national public, 
keeping class contradiction safely hidden.

My analysis in the second chapter was framed by a 'tripod' of publics; Racialised, Gendered and Economic publics. Subaltern racialised publics, in particular Māori publics, were named more than Pākehā, the dominant group: Māori made up over $90 \%$ of references to either Māori or Pākehā in both party releases and press coverage. Qualitatively, the National Party's official discourse on 'Māori Affairs' articulated a programme of bourgeois hegemony in the field of cultural recognition. The Party rushed for 'settlement', seeking to foreclose the articulation of indigenous grievances. Yet over a period of increased settlement, inequality within Maoridom has only increased (Poata-Smith, 2005). The National Party emphasised cultural recognition of an economically privileged layer ('iwi leaders'), without adequate measures to address the poverty of most Māori. This is consistent with Nancy Fraser's (2005) analysis of contemporary feminism whereby gains in recognition have been traded for losses in redistribution (p. 299). Fraser herself identified that this bargain was "was not limited to feminism," and had a broader impact on social movements (299-300).

In keeping with the pattern of subaltern recognition, women were named more frequently than men, at over $60 \%$ of both party and press release references to gender. My analysis assumed again that the dominant group was encoded in terms like 'New Zealander'. Men were sometimes named in relation to women and feminism, whereas sometimes the term 'men' served as a signifier for working class publics. Like their programme for Māori, the National Party's programme for women traded redistribution for recognition. While the party celebrated formal equality, and recognised the achievements of bourgeois women, poor and working-class women did not find the same recognition. Rather, poor women were denigrated through categories such as 'beneficiary'. Press coverage also equated working-class identity with masculinity, despite the feminisation of poverty and the fact that the majority of union members in Aotearoa/New Zealand are women.

Economic categories tended to be more generic than explicitly Racialised and Gendered categories, with classless terms like 'the market' and 'the economy' rife in dominant discourse. These terms reified economic relations as simply the terrain of existence, rather than historically specific social relations of power. Conversely, the bourgeoisie was assumed to be a universal class, as the interests of business 
were equated with the interests of the public as a whole (for example, the headline "Business confidence bodes well for everyone").

The third chapter outlined enforced characteristics of the national political 'centre'. My content analysis found that major parties were less likely to self-identify as 'left' or 'right' than identify their rivals as such, indicating a common motivation to claim a centrist, non-partisan public space. Similarly, major parties were more likely to name their rivals' potential coalition partners than their own; just over $90 \%$ of Labour's references to minor parties named ACT, and all of the National Party's references to minor parties named the Greens or Internet Mana. This combined negative emphasis on minor parties may contribute to a sense of political risk, that minor party extremists may jeopardise the political centre. Neoliberal parties and business voices also tended to portray MMP, which benefits minor parties, as a political unstable risk to the neoliberal project.

I also argued that press socially construct the political 'centre' in their political reportage. The press were more likely to use third-person pronouns than first-person, indicating a tendency to stand 'outside' the political process. This genre convention implies an objective perspective, rather than political partisanship. However, the empiricism of press coverage limited the ability to challenge the terms of political representation, instead reproducing the existing institutional political spectrum. The relationship between party press releases and newspaper coverage was not direct: rather than directly reprinting press releases, newspapers tended to use similar terms independently of press releases, or interview party spokespeople (who often used very similar terms to press releases). Therefore while press releases were not directly reproduced, major parties had an agenda setting role. Further, while the press covered both minor and major parties, they were more likely to report on 'sensational' minor party figures. Controversial figures like Kim Dotcom, Winston Peters and Colin Craig received far more coverage than the leaders of the Green Party, the third largest party in Aotearoa/New Zealand. These limitations in dominant discourse may be further exacerbated in future by the merger of major media companies NZME and Fairfax, meaning that both major press groups will be owned by one company, and support for journalism may be further cut (Peacock, 2016). This coverage may discourage civic engagement for those alienated by dominant discourse. The Civics and Media Project suggested that support for public interest journalism should be expanded in Aotearoa/NZ, particularly through publicly 
owned multi-platform media, to keep citizens informed and politically engaged (Civics and Media Project, 2016). Independently organised media can also assist the formation of critical counterpublics, independent of both the state and monopoly capital (Fraser, 1990).

Critical discourse analysis of party and press material established three ways that dominant discourses produced a bounded, legitimised political public. The analysis deployed the concept of Disciplined Democracy in reference to a normative limitation on the terms of public participation; social movement activity was portrayed as dangerous or unnecessary, while the act of voting was encouraged. Publics were therefore interpellated as compliant subjects, encouraged to legitimate existing political forms, rather than challenge them. Other forms of democratic participation were portrayed at best misguided, at worst dangerous (see Hopkins, 2011). In Gramsci's terms, "The "normal" exercise of hegemony on the now classic terrain of the parliamentary regime is characterized by a combination of force and consent which balance each other so that force does not overwhelm consent but rather appears to be backed by the consent of the majority" (1992, p. 155-156). When cops clear out Occupy Auckland, it is important that the operations of the New Zealand state appear to have majority consent; citizens must do their duty and vote.

I coined the term Secular Heteronormativity in reference to the avoidance of explicit references to religion and sexuality among political parties. This leaves heteronormativity unchallenged, while courting conservative publics threatened by a secular regime. Finally, I examined the production of an expanding criminalised 'nonpublic', with all parties enthusiastic about prison labour schemes which pay a tiny fraction of the minimum wage. This discursive and material production of a criminal Nonpublic seeks conversely to produce a lawful public, identifying with the state against subalterns.

The notion of 'publics' and 'nonpublics' proved useful in distinguishing between groups invoked by dominant discourse (particularly 'New Zealanders') and disavowed groups (eg 'foreigner', 'beneficiary'). My analysis found a strong overlap between groups scapegoated as nonpublics and the 'missing million' of non-voters. As previously mentioned, opposition parties scapegoated 'foreigners' for the economic crisis, overlapping with the overrepresentation of recent migrants in non-voting statistics (Chapter 1). The ruling neoliberal party 'recognised' economically privileged layers of women and Māori, 
while working-class and impoverished communities - disproportionately women and Māori - were not recognised as a legitimate constituency (Chapter 2). Youth, again overrepresented among non-voters, were cast by major parties as a dangerous nonpublic that would have to be reintegrated into productive society (Chapter 3). Mainstream press coverage focused negative attention on non-voters per se (Chapter 3). Parties and press also produced queers as a nonpublic, primarily through silence, although the political regime has made some liberal concessions to queer social movements (Chapter 3). However research on non-voters has not factored sexuality in - further research is needed on the relationship between LGBT publics and dominant political discourse. My analysis does not comprehensively cover all potential (non)publics; for example, disabled people did not show up in the data, a point that could be investigated further. In producing nonpublics, dominant discourse hailed an assumed public of older, Pākehā, heterosexual, middle-class homeowners (or prospective homeowners/mortgagees), under the generic term 'New Zealanders'. This limited representation may contribute to the democratic deficit.

\section{Challenges to dominant discourse}

In addition to characterising dominant discourse, I argued that the MANA Movement sought to challenge this discourse. In my content analysis, economically polarised language was more common among 2011 party releases than anywhere else, particularly represented in MANA press releases. In MANA's formative 2011 ferment, the party at time reflected the dominant Right-WIng Populism of other opposition parties, yet also articulated a nascent Left-Wing Populism. In linking Māori and Pākehā publics on the basis of working-class constituency, MANA integrated demands for (cultural) recognition and (economic) redistribution, thereby requiring an new form of (political) representation; what Nancy Fraser (2005) calls "three-dimensional politics" (p. 305-306). MANA named its constituency as te pani me te rawakore (the poor and the powerless), a subaltern rather than national public. My distinction between Left-Wing Populism and Right-Wing Populism was therefore fruitful, enabling identification of a minority discourse of Left-Wing Populism. Despite a media environment that tended to exacerbate political convergence, MANA found coverage for its populist campaigning on 'inequality' (in 2011) and 'surveillance' (in 2014). Therefore while press reproduced the existing parliamentary spectrum, this included minor party concerns to a certain degree. However, Harawira lost his seat after the politically ambiguous alliance with Kim Dotcom, perhaps reflecting a perceived abandonment of principles. 
This analysis suggests that a gap remains for a coherent left-wing party to engage popular discourse. While this party may employ electoral tactics, the 'quick fix' of poll-driven politics must be rejected, in favour of developing a cross-sectoral 'chain of equivalence' with a common programme. The party should seek to articulate the grievances and aspirations of those relegated to 'nonpublic' status in bourgeois discourse. The party should also develop an "affective infrastructure" able to collectively support the initiative of individuals (Dean, 2016). The party's common programme must integrate the three dimensions of (economic) redistribution, (cultural) recognition and (political) representation (Fraser, 2005). As discourse polarises between neoliberalism and racist nationalism, this party should also articulate a progressive internationalism.

We must also consider why existing left projects have so little currency. While the general public tends to consider 'inequality' important (Roy Morgan, 2014), left-wing political projects are marginal (even before the alliance with Dotcom, MANA failed to reach a broader Pākehā public). While this can be partly explained through the party and media mechanisms previously covered, understanding this dynamic may also require a participatory approach to considering ideology and working-class agency. My project consciously focused on media 'encoding', with questions of audience 'decoding' outside the scope of analysis (Hall, 2001). In academic-disciplinary terms, an 'audience study' could address these questions. Such a study may consider receptiveness to dominant messages; what range of media audience members use (including social media, television, radio et al); intertextual interpretation; whether social or family networks affect interpretation; membership in political parties; membership in 'non-political' voluntary organisations (churches, sports clubs); the role of preconceived beliefs; participants' assessment of the existing political environment; class, race and gender of participants; and at a general level, the role of situated interpretation. Having textually identified a gap on the political left in Aotearoa/New Zealand, a study specifically on the possibilities for communist or left-wing consciousness may consider receptiveness to counter-messages; access to alternative media sources; membership in non-parliamentary political groups; the role of oppositional decoding, and what political alternative participants may imagine.. 


\section{Works Cited}

Ahmed, S., 2007. "A phenomenology of whiteness". Feminist Theory August 2007 vol. 8 no. 2 pp. 149168

Ailes, E., 2015. "Election 2015: Who are the non-voters?" BBC News online article 6 May 2015 [WWW Document]. URL http://www.bbc.com/news/election-2015-32527697 (accessed 8.26.15).

Alexa, 2014. "Top Sites in New Zealand" Alexa online page published by Amazon, no date. [WWW Document]. URL http://www.alexa.com/topsites/countries/NZ (accessed 22.09.2016)

Alexander, M., 2010. The New Jim Crow. New York: The New Press.

Althusser, L., 1971. "Ideology and Ideological State Apparatuses (Notes towards an Investigation)". In Lenin and Philosophy and Other Essays. Verso.

Althusser, L., 1962. "Contradiction and Overdetermination”. In Part III of For Marx. Penguin Press.

Amore, K., 2016. "Homelessness Accelerates Between Censuses" University of Otago news article 3 June 2016. [WWW Document]. URL http://www.otago.ac.nz/news/news/otago613529.html (accessed 31.08.2016)

Anae, M., 2012. "Overstayers, Dawn Raids and the Polynesian Panthers". In Sean, Mallon. Tangata O Le Moana: New Zealand and the People of the Pacific. Te Papa Press.

Anderson, B., 1982. Imagined Communities. Verso.

Anderson, I., 2014. "Rearranging the deck chairs on the Titanic? The Labour Party and MANA" Fightback online article 24 July 2014. [WWW Document]. URL http://tinyurl.com/hjmudsz (accessed 17.07.2016) 
Anderson, P., 1976. "The Antinomies of Antonio Gramsci". New Left Review, 1/100, November December 1976.

APNZ, 2011. "Strong reaction to damning TV child poverty doco" NZ Herald online article November 23 2011. [WWW Document]. URL http://tinyurl.com/hovgof2 (accessed 21.09.2016)

Armstrong, J., 2014a. "Winners, losers before we vote" The New Zealand Herald [Auckland, New Zealand] 19 September 2014, pp. A014

Armstrong, J., 2014b. "Dotcom's last chance to win credibility" The New Zealand Herald [Auckland, New Zealand] 15 September 2014, pp. A008

Awatere Huata, D., 1984. Māori sovereignty. Broadsheet, Auckland, NZ.

Banaji, J., 2016. "Stalin's Ghost Won't Save Us from the Spectre of Fascism: A Response to Prakash Karat" Sabrang India online article 12 September 2016. [WWW Document]. URL http://tinyurl.com/zhyu6v4 (accessed 13.09.2016)

Beetham, D., S. Bracking, I. Kearton, N. Vittal and S. Weir (eds), 2002. The State of Democracy: assessments in eight nations around the world. The Hague: Kluwer Law International

Bennett, A., 2012. "Crafar sale: Most Kiwis prefer local group's bid" NZ Herald online article 24 November 2012. [WWW Document]. URL http://tinyurl.com/gqmt4cm (accessed 05.06.2016)

Bennett, P., 2014. "National to reduce benefit numbers by 25 per cent" National Party Press Release 17 September 2014. [WWW Document]. URL http://tinyurl.com/zhfrqyr (accessed 20.06.2016)

Berlant, L., Warner, M., 1998. "Sex in Public". Critical Inquiry Vol. 24, No. 2, Intimacy (Winter, 1998), pp. 547-566 
Berry, R., 2007. "PM snubs Key's invitation to visit the 'underclass'" NZ Herald online article 1 February 2007. [WWW Document]. URL http://tinyurl.com/zsvce4w (accessed 21.08.2016)

Bieler, A., Morton, A.D., 2001. "The Gordian Knot of Agency—Structure in International Relations:A Neo-Gramscian Perspective". European Journal of Internatioanl Relations 7, pp. 5-35.

Bootham, L., 2016. "Consultation on Māori land law 'nonsense"” Radio New Zealand Report 9 February 2016. [WWW Document]. URL http://tinyurl.com/zrdh8pn (accessed 20.06.2016)

Boston, J., Chapple, S., 2015. The Child Poverty Debate: Myths, Misconceptions and Misunderstandings. Bridget Williams Books: Wellington.

Bourdieu, P., Gisèle, S., Ferguson, P.P., Nice, R.W., and Wacquant, L.J.D., 2010. Sociology Is a Martial Art: Political Writings by Pierre Bourdieu. New York: New.

Boucher, G., 2008. "Crop Circles in the Postmarxian Field: Laclau and Mouffe on Postmodern Socialist Strategy". In G Boucher The Charmed Circle of Ideology: A Critique of Laclau \& Mouffe, Butler \& Zizek. Melbourne: re.press. Open source e-book. Accessed online 04/03/2014

Bowron, J., 2014. "Divorcing democracy not an option, despite fatigue" The Dominion Post [Wellington, New Zealand] 8 September 2014, pp. A5

Bradford, S., 2016. "Fractured Fightback" CounterFutures: Left Thought and Practice Aotearoa 1, Published bi-annually by CounterFutures, Printed by Rebel Press: Wellington.

Brady, A., Schirato, T., 2010. Understanding Judith Butler, Understanding contemporary culture. SAGE, London.

Brown, R., 2011. "The Politics of Absence" Public Address article 3 October 2011. [WWW Document] URL http://tinyurl.com/h74de57 (addressed 15.06.2016) 
Brownlee, G., 2014. "Transmission Gully Finally Underway” National Party Press Release 8 September 2014. [WWW Document]. URL http://tinyurl.com/z947lua (accessed 06.06.2016)

Bryson, L., 1992. The State and Welfare: Who Benefits? London: Macmillan

Business Herald, 2014. "Business confidence bodes well for everyone" Business_ Herald online article 11 September 2014. [WWW Document]. URL http://tinyurl.com/zgk5gu2 (accessed 21.08.2016)

Butler, J., 1990. Gender Trouble. New York: Routledge.

Butler, J., 1993. "Gender is Burning: Questions of Appropriation and Subversion". In Bodies that Matter: On the Discursive Limits of Sex. Routledge: New York

Butler, J., 2013. "Bodies in Alliance and the Politics of the Street (excerpts)". In Gregory Sholette \& Oliver Ressler (eds) It's the Political Economy, Stupid. London: Pluto Press

Carlyle, T., 1849. "Occasional Discourse on the Negro Question". Fraser's Magazine for Town and Country, Vol. XL, pp. 670-679.

CBB, 2016. "Submission to the Commerce Commission on Wilson \& Horton Limited and Fairfax New Zealand Limited - Application for authorisation of a business acquisition" Prepared for the Coalition for Better Broadcasting (CBB) by Peter Thompson, July 2016

Chapman, K., 2012. "McKellan's words to PM over gay shirt saga" Stuff online article 11 November 2012. [WWW Document]. URL http://tinyurl.com/c5ymugn (accessed 19.06.2016)

Cooke, M., 2013. "Marx on the 'Jewish question': anti-Semitic or a cogent critique of liberalism". Links International Journal of Socialist Renewal online article July 2 2013. [WWW Document]. URL http://links.org.au/node/3429 (accessed 11.08.2015) 
Cox, R.W., 1985. "Realism, Positivism or Historicism". In RW Cox \& TJ Sinclair, Approaches to World Order. Cambridge: Cambridge University Press.

Cox, R.W., 1987. "Production, the State and Change in World Order". In Ernst-Otto Czempiel and James N. Rosenau (eds) Global Changes and Theoretical Challenges: Approaches to World Politics for the 1990s. Lexington, MA: Lexington Books

Crispe, I., 2011. "Hone's date with Pakeha" The New Zealand Herald [Auckland, New Zealand] 6 November 2014, pp. A005

Cunliffe, D., 2011a. "Empty promises on asset sales unconvincing" Labour Party Press Release 24 November 2011. [WWW Document]. URL http://tinyurl.com/jjvhbv3 (accessed 07.06.2016)

Cunliffe, D., 2011b. "John Key's asset sales an epic fail for NZ" Labour Party Press Release 13 November 2011. [WWW Document]. URL http://tinyurl.com/gkwewmr (accessed 05.06.2016)

Cunliffe, D., 2014. "Labour recommits to Pike River families" Labour Party Press Release 6 September 2014. [WWW Document]. URL http://tinyurl.com/gwzp7yw (accessed 30.05.2016)

Davidson, N., 2015. "Neoliberalism as the Agent of Capitalist Self-Destruction" Salvage online article [WWW Document]. URL http://www.salvage.zone/davidson.html (accessed 16.08.15).

Davis, A.Y., 2003. Are Prisons Obsolete? New York: Seven Stories Press

Davis, A., 2010. Political Communication and Social Theory. Routledge: London.

Davison, I., 2011. "Mana fills void as rivals drift to centre". The New Zealand Herald [Auckland, New Zealand] 23 November 2011, pp. A006 
Davison, I., 2014. "Left backs National's plan for 'working prisons'” The New Zealand Herald [Auckland, New Zealand] 11 September 2014, pp. A014

Dean, J., 2003. "Why the Net is Not a Public Sphere". In Constellations: An International Journal of Critical and Democratic Theory, Volume 10, Number 1, pp. 95-112.

Dean, J., 2016. Crowds and Party. Verso.

Delahunty, C., 2011. "Green Party will change law to ensure equal pay" Green Party Press Release 20 November 2011. [WWW Document]. URL http://tinyurl.com/hqw4uz4 (accessed 30.05.2016)

Dominion Post, 2014. "Editorial: A world of reasons to vote." The Dominion Post [Wellington, New Zealand] 11 September 2014, pp. A08

Dorey, P., 2009. "'Sharing the proceeds of growth': Conservative Economic Policy under David Cameron" The Political Quarterly, Vol. 80, No. 2, The Political Quarterly Publishing Co. Ltd. 2009

Dorey, P., 2010. British Conservatism: The Politics and Philosophy of Inequality. London, US: I.B. Tauris

Duggan, L., 2002. "The New Homonormativity: The Sexual Politics of Neoliberalism". In Russ Castronovo and Dana D. Nelson (eds) MATERIALIZING DEMOCRACY: Toward a Revitalized Cultural Politics, Durham and London: Duke University Press

Du fresne, K., 2012. The Dominion Post [Wellington, New Zealand] 16 November 2012, pp. A11

Dwyer, M., 2015. "Sole parents in poverty" Policy Quarterly - Volume 11, Issue 1 - February 2015, pp. 19-24

Edelman, L., 2004. No Future: Queer Theory and the Death Drive. Durham and London: Duke 
University Press.

Edwards, B., 2008. "Political finance and Inequality in New Zealand" New Zealand Sociology Volume 23 Number 2, 2008, Sociological Association of Aotearoa/New Zealand

Eisler, LD., 2007. "An Application of Foucauldian Concepts to Youth in the Criminal Justice System: A Case Study." Critical Criminology (2007) 15: pp. 101-122

Engels, F., 1884. The Origin of the Family, Private Property and the State. Written 1884; translated by Alick West in 1942; online version transcribed for Marxists.org by Zodiac/Brian Williams 1993; proofed and corrected by Mark Harris 2010. [WWW Document]. URL https://www.marxists.org/archive/marx/works/1884/origin-family/ (accessed 16.08.15)

Engels, F., 1890. "Engels to J. Bloch In Berlin". Letter written 1890; translated by Sidney Hook, transcribed for Marxists.org by Einde O'Callaghan 2006. [WWW Document]. URL http://tinyurl.com/hhgmu9k (accessed 30.05.2016)

Fairclough, N. \& Graham, P., 2002. "Marx as a Critical Discourse Analyst: The genesis of a critical method and its relevance to the critique of global capital" Estudios de Sociolingüística 3(1), 2002, pp. $185-229$

Family First, 2014. "The marriage pledge - Applying it at the ballot box 2014" Family First Press Release 24 July 2014. [WWW Document]. http://tinyurl.com/hogzw4k (accessed 22.05.2016)

Farndale, N., 2009. "Tony Benn: Making mistakes is part of life" Telegraph online article 12 August 2009 [WWW Document]. URL http://tinyurl.com//8d526u (accessed 19.07.2016)

Ferguson, P., 2014. "Kim Dotcom, the far left and Te Tai Tokerau: an autopsy" Redline blog entry 28 November 2014. [WWW Document]. URL http://tinyurl.com/hgrrogg (accessed 23.05.2016) 
Finlayson, C., 2014. "Treaty and Maori Affairs Policy Released" National Party Press Release 12 September 2014. [WWW Document]. URL http://tinyurl.com/okox9vd (accessed 06.11.15)

Fisher, D., 2014. “'Don't you dare release anything' " The New Zealand Herald [Auckland, New Zealand] 19 September 2014, pp. A003

Flavell, T.U., 2014. 'Voters urged to look past the lies and half-truths" Māori Party Press Release 19 September 2014. [WWW Document]. URL http://tinyurl.com/gpfxxya (accessed 21.05.2016)

Fraser, N., 1990. "Rethinking the Public Sphere: A Contribution to the Critique of Actually Existing Democracy". Social Text, No. 25/26 (1990), pp. 56-80. Duke University Press

Fraser, N., 2005. "Mapping the Feminist Imagination: From Redistribution to Recognition to Representation" Constellations: An International Journal of Critical and Democratic Theory, Volume 12, Issue 3, September 2005, pp. 295-307

Foss, C., 2011. "National committed to security, wellbeing of older Nzers" National Party Press Release 17 November 2011. [WWW Document]. URL http://tinyurl.com/jythhxg (accessed 15.06.2016)

Foucault, M., 1972. The Archaeology of Knowledge. Pantheon Books: New York.

Foucault, M., 1977. Discipline and Punish, translated from the French by Alan Sheridan. Pantheon Books: New York.

Foucault, M., 1980. "ON POPULAR JUSTICE: A Discussion with Maoists". In Power/Knowledge: Selected Interviews and Other Writings, 1972-1977. Vintage: New York.

Gibson, A., 2015. "Special investigation: Auckland house prices" NZ Herald online article 11 July 2015 [WWW Document]. URL http://tinyurl.com/o3oxf2t (accessed 05.06.2016) 
Giddens, A., 1998. The Third Way: The Renewal of Social Democracy. Polity.

Goff, P., 2011a. "Goff tells Aussie bankers to keep their hands off our assets" Labour Party Press Release 14 November 2011. [WWW Document]. URL http://tinyurl.com/jjanubj (accessed 06.06.2016)

Goff, P., 2011b. "Phil Goff remembers the men and families of Pike River" Labour Party Press Release 19 November 2011. [WWW Document]. URL http://tinyurl.com/heg4qmw (accessed 30.05.2016)

Goodhew, J., 2014. "Celebrating women's right to vote" National Party Press Release 16 September 2011. [WWW Document]. URL http://tinyurl.com/zseg5oq (accessed 30.05.2016)

Gramsci, A., 2011a. Prison Notebooks: Volume I. Columbia University Press.

Gramsci, A., 2011b. Prison Notebooks: Volume II. Columbia University Press.

Gramsci, A., 2011c. Prison Notebooks: Volume III. Columbia University Press.

Gregory, M., 2014. "Should socialists support the Internet-Mana alliance? A Reply" International Socialist Organisation (Aotearoa/NZ) blog post 3 July 2014. [WWW Document]. URL https://iso.org.nz/2014/07/03/2103/ (accessed 23.05.2016)

Grey, S.; Sedgwick, C., 2013. "The Contract State and Constrained Democracy." Policy Quarterly Volume 9, Issue 3 - August 2013, pp. 3-10

Groser, T., 2011a. “Japan seeks to join Trans Pacific Partnership Negotiation” National Party Press Release 12 November 2011. [WWW Document]. URL http://tinyurl.com/zzeak2h (accessed 06.06.2016)

Groser, T., 2011b. "Thailand-NZ Closer Economic Partnership Agreement leads to growing trade" 
National Party Press Release 12 November 2011. [WWW Document] URL http://tinyurl.com/zo9obxd (accessed 06.06.2016)

Gurhanli, H., 2013. "Post-Foundationalism of Laclau and Oakeshott: Politics of Faith, Scepticism and Populism" Annales Philosophici 7 (2013), pp. 26-37

Guy, N., 2014. "National launches primary industries policy" National Party Press Release 11 September 2014. [WWW Document]. URL http://tinyurl.com/he5mta2 (accessed 06.06.2014)

Hager, N., 2006. The hollow men: a study in the politics of deception. Nelson, NZ: Craig Potton Publishers.

Hager, N., 2014. Dirty politics : How attack politics is poisoning New Zealand's political environment. Nelson, NZ: Craig Potton Publishers.

Habermas, J., 1962. The Structural Transformation of the Public Sphere: An enquiry into a category of bourgeois society, translated by Thomas Burger and Frederick Lawrence. MIT Press

Hall, S., 2001. "Encoding, Decoding". In The Cultural Studies Reader, 2nd edition, Simon During (ed) 2001. London: Routledge.

Hall, S., 2006. "The problem of ideology: Marxism without guarantees". In Kuan-Hsing Chen, David Morley (eds) Stuart Hall: Critical Dialogues in Cultural Studies. Routledge.

Hallahan, K., 1999. "Seven Models of Framing: Implications for Public Relations" JOURNAL OF PUBLIC RELATIONS RESEARCH, 11(3), pp. 205-242. Copyright (C) 1999, Lawrence Erlbaum Associates, Inc.

Hansard, 2015. Audit of Political Engagement 12: The 2015 Report. London: Hansard Society. 
Harawira, H., 2011. "Hone Harawira - State of the Nation Speech" MANA Movement Press Release 23 November 2011. [WWW Document] URL http://tinyurl.com/h4khoc5 (accessed 22.05.2016)

Harawira, H., 2014. "How come the PM only pays $2.8 \%$ of his income in tax" MANA Movement Press Release 7 September 2014. [WWW Document]. URL http://tinyurl.com/gsubax4 (accessed 22.05.2016)

Harvey, D. 2005. A Brief History of Neoliberalism. Oxford University Press.

Harvey, D., 2010. “What Technology Reveals”. In A Companion To Marx's Capital. Verso.

Harvey, D., 2014. Seventeen Contradictions and the End of Capitalism. London: Profile Books.

Hay, C., 2007. Why We Hate Politics. Cambridge: Polity.

Heather, B., 2013. "Married gay minister celebrates as 'full citizen"' Stuff online article 6 November 2013 [WWW Document]. http://tinyurl.com/howa8cs (accessed 22.05.2016)

Herald on Sunday, 2014. "It is your decision, don't give it away" The New Zealand Herald [Auckland, New Zealand] 14 September 2014, pp. A032

Hokowhitu, B., 2013. "Producing Indigeneity." In Peters, Evelyn, and Andersen, Chris (eds) Indigenous in the City : Contemporary Identities and Cultural Innovation. Vancouver: UBC Press.

hooks, b., 1999. Ain't I A Woman: Black Women and Feminism. South End Press.

Hope, W., 1996. "A Short History of the Public Sphere in Aotearoa / New Zealand" Continuum: The Australian Journal of Media and Culture, Vol 10 No 1 1996, pp. 12-32

Hope, W., 2012. "New Thoughts on the Public Sphere in Aotearoa New Zealand". In Martin Hirst, Sean 
Phelan and Verica Rupar (eds) Scooped: The Politics and Power of Journalism in Aotearoa New Zealand. Auckland: AUT Media

Hopkins, J., 2011. "Remember who owns the election" The New Zealand Herald [Auckland, New Zealand] 25 November 2011, pp. A017

Hunt, C., 2014. "Household debt: A cross-country perspective" Reserve Bank of New Zealand Bulletin Volume 77, No. 4, October 2014, pp. 1-13

Ihaka, J., 2014. "Parties on same page in troubled electorate" The New Zealand Herald [Auckland, New Zealand] 12 September 2014, A014

IMF, 2014. "New Zealand" IMF Report June 2014 [WWW Document]. URL http://tinyurl.com/gvrnq53 (accessed 06.06.2016)

Jeffries, S., 2016. "The Frankfurt School: A Timeline" Verso online article 20 September 2016. [WWW Document]. URL http://tinyurl.com/juuzod5 (accessed 26.09.2016)

Jovanovski, I., 2016. “Translating Laclau's 'populist reason' in political praxis: experiences from Southern Europe". Paper presented for Social Movements and Social Change III: The academic and Activist Interface, Wellington.

Joyce, S., 2011. "National committed to securing NZ's UFB future" National Party Press Release 13 November 2011. [WWW Document]. URL http://tinyurl.com/jdnox2q (accessed 21.08.2016)

Joyce, S., 2014a. "National targets more skills training for Maori" National Party Press Release 12 September 2014. [WWW Document]. URL http://tinyurl.com/p6zxdgb (accessed 06.11.15)

Joyce, S., 2014b. "Ten key initiatives to boost Northland Economy" National Party Press Release 12 September 2014. [WWW Document]. URL http://tinyurl.com/nzkd438 (accessed 06.11.15) 
Joyce, S., 2014c. "The left hits "peak spending"” National Party Press Release 14 September 2014. [WWW Document]. URL http://tinyurl.com/nzkd438 (accessed 06.11.15)

Joyce, S., 2014d. "Next 10 things for Business Growth Agenda" National Party Press Release 15 September 2014. [WWW Document]. URL http://tinyurl.com/zpf6j97 (accessed 06.06.2016)

Judt, T., 2010. The Memory Chalet.. Penguin Books

JustSpeak, 2014. Unlocking Prisons: How We Can Improve New Zealand's Penal System. JustSpeak

KAROL, 2013. "That politician got amnesia again" April 262013 The Standard blog post [WWW Document]. URL http://tinyurl.com/jhps58t (accessed 10.06.2016)

Kelsey, J., 2015. The FIRE Economy: New Zealand's Reckoning. Bridget Williams Books

Key, J., 2011a. "National to build a better education system" National Party Press Release 21 November 2011. [WWW Document]. URL http://tinyurl.com/h7xylwl (accessed 08.06.2016)

Key, J., 2011b. "PM welcomes significant Pacific trade deal progress" National Party Press Release 13 November 2011. [WWW Document]. URL http://tinyurl.com/gayre3c (accessed 08.06.2016)

Key, J., 2011c. "National to step up tempo of trade missions" National Party Press Release 16 November 2011. [WWW Document]. URL http://tinyurl.com/hqor8pc (accessed 28.08.2016)

King, A., 2011. "Women's refuges not getting enough support" Labour Party Press Release 14 November 2011. [WWW Document]. URL http://tinyurl.com/jtcaatm (accessed 30.05.2016)

Klikauer, T., 2013. "What is Mangerialism?" Critical Sociology 0(0), pp. 1-17 
Korsch, K., 1938. Karl Marx. Chapman \& Hall.

Kriss, S., 2015a. "Building Norway: a critique of Slavoj Žižek" Idiot Joy Showland blog post 11 September 2015. [WWW Document] URL https://samkriss.wordpress.com/2015/09/11/buildingnorway-a-critique-of-slavoj-zizek/ (accessed 20/05/2016)

Kriss, S., 2015b. "In Defence of Fantasy: A further response to Slavoj Žižek" Idiot Joy Showland blog $\begin{array}{lllll}\text { post } & 17 & \text { November } & \text { 2015. } & \text { [WWW }\end{array}$ https://samkriss.wordpress.com/2015/11/17/in-defence-of-fantasy-a-further-response-to-slavojzizek/ (accessed 20/05/2016)

Laclau, E., 1977. Politics and Ideology in Marxist Theory: Capitalism, Fascism, Populism. London and Atlantic Highlands, NJ: Humanities Press.

Laclau, E., 2005a. On Populist Reason. Verso.

Laclau, E., 2005b. "Populism: What's in a Name?" In Francisco Panizza (ed) Populism and the Mirror of Democracy. Verso.

Laclau, E., Mouffe, C., 2001. Hegemony and Socialist Strategy: Towards a Radical Democratic Politics, 2nd edition (first published 1985). Verso.

Lakoff, G., 2004. Don't Think of an Elephant! Know Your Values and Frame The Debate. US: Chelsea Green Publishing Company.

Lasswell, Harold D. "The structure and function of communication in society". In Lyman Bryson (ed) The Communication of Ideas: A Series of Addresses. New York: Institute for Religious and Social Studies.

Levi-Strauss, C., 1963. Structural Anthropology, New York: Basic Books. 
LINZ, 2016. "Property transfers and tax residency data" Land Information New Zealand report last updated 10 May 2016. [WWW Document] URL http://tinyurl.com/z3h8fhl (accessed 06.06.2016)

Lole-Taylor, A., 2014. "Working prisons not new” New Zealand First Press Release 12 September 2014. [WWW Document]. URL http://nzfirst.org.nz/news/working-prisons-not-new (accessed 21.05.2016)

Lotu-liga, P., 2014. "New Zealand Samoans gearing up for game" National Party Press Release 9 September 2014. [WWW Document]. URL http://tinyurl.com/jswjl48 (accessed 06.06.2016)

Lucassen, M.F.G., Clark, T. C., Moselen, E., Robinson, E.M., \& The Adolescent Health Research Group, 2014. Youth'12: The Health and Wellbeing of Secondary School Students in New Zealand: Results for Young People Attracted to the Same Sex or Both Sexes. Auckland: The University of Auckland.

Lukacs, G., 1923. History and Class Consciousness. Written in 1923; Published by Merlin Press, 1967; Transcribed for Marxists.org: Andy Blunden. [WWW Document]. URL http://tinyurl.com/gwanzoo (accessed 01.06.2016)

MacDonald, F., 2016. "Has the PM mistaken himself for a flag?" Radio New Zealand blog bost 29 February 2016. [WWW Document]. URL http://tinyurl.com/jua6vhz (accessed 10.06.2016)

Macnamara, J., 2005. "Media content analysis: Its uses; benefits and best practice methodology" Asia Pacific Public Relations Journal, 6(1), pp. 1-34. 1 University of Technology Sydney

MANA, 2011. "MANA Movement - Foreign Policy Release" MANA Press Release 21 November 2011. [WWW Document]. URL http://tinyurl.com/jul34yl (accessed 05.06.2016) 
MANA Rangatahi, 2011. "We are the 99\% - MANA Rangatahi" MANA Movement Press Release 14 October 2011. [WWW Document]. URL http://tinyurl.com/je44dhs (accessed 23.05.2016)

Marcuse, H., 1965. "Repressive Tolerance". In Wolff, R.P., Moore, B., and Marcuse H., A Critique of Pure Tolerance. Beacon Press, Boston.

Marx, K., 1844. "On The Jewish Question." Written in Autumn 1843; First Published February, 1844 in Deutsch-Französische Jahrbücher; Proofed and Corrected for Marxists.org by Andy Blunden, Matthew Grant and Matthew Carmody, 2008/9. [WWW Document] URL https://www.marxists.org/archive/marx/works/1844/jewish-question (accessed 11.08.2016)

Marx, K., 1867. Capital: A Critique of Political Economy: Volume One. First published in German in 1867; Source: First English edition of 1887; Publisher: Progress Publishers, Moscow, USSR; Translated: Samuel Moore and Edward Aveling, edited by Frederick Engels; Transcribed for Marxists.org by Zodiac et al (1995-1996); Proofed: by Mark Harris (2010), Dave Allinson (2015). [WWW Document]. http://tinyurl.com/p25t9v5 (accessed 01.06.2016)

McCully, M., 2014. "NZ welcomes Fiji's return to the polls" National Party Press Release 18 September 2014. [WWW Document]. URL http://tinyurl.com/ju9fpq7 (accessed 06.06.2016)

McNeil, D., 2016. "Utopias Old and New" CounterFutures: Left Thought and Practice Aotearoa, 1, Published bi-annually by CounterFutures, Printed by Rebel Press: Wellington.

McRae, O., 2014. "Prison Reform on the Path to Prison Abolition" ISO online article 15 September 2014 [WWW Document] URL https://iso.org.nz/2014/09/15/prison-reform-on-the-path-to-prisonabolition/ (accessed 13/05/2016)

Miller, R, 2015. Democracy in New Zealand. Auckland: Auckland University Press. 
Mitchell, C., 2015. "The language of John Key, akshually" Stuff online article 3 January 2015. [WWW Document]. URL http://tinyurl.com/gp89z4j (accessed 15.06.2016)

Moir, J., 2015. "No housing crisis in Auckland: John Key" Stuff online article 18 May 2015 [WWW Document]. URL http://tinyurl.com/jf9r3m4 (accessed 05.06.2016)

Mon News, 2010. "What is meant by Disciplined Democracy?" Mon News online article 27 October 2010. [WWW Document]. URL http://tinyurl.com/ze9y7w2 (accessed 18.07.2016)

Morgan v Attorney General, 1965. New Zealand Law Report 134. New Zealand Council of Law Reports.

Mulligan, P., 2011. "Council within rights to evict Occupy squatters" The New Zealand Herald [Auckland, New Zealand] 25 November 2011, A17

Mullord, A., 2011. "Child poverty doco 'apolitical' - filmmaker" Newshub online article 23 November. [WWW Document]. URL http://tinyurl.com/h4chk4y (accessed 21.09.2016)

Negt. K., Kluge, A., 1972. Public Sphere and Experience Toward an Analysis of the Bourgeois and Proletarian Public Sphere. University of Minnesota Press.

Neuendorf, K., 2002. The Content Analysis Guidebook. Thousand Oaks, CA: Sage Publications.

Newbold, C., Boyd-Barrett, O., \& Van Den Bulck, H., 2002. The media book. London: Arnold (Hodder Headline).

Ng, K., 2015. "My last name sounds Chinese" Public Address blog post 11 July 2014. [WWW Document]. URL http://publicaddress.net/onpoint/my-last-name-sounds-chinese/ (accessed 06.06.2016)

NPIP, 2016. Abolitionist Demands: Towards the End of Prisons in Aotearoa. Auckland: No Pride in 
Prisons Press.

NZ Herald, 2011. "MMP leads to divisive government" The New Zealand Herald [Auckland, New Zealand] 17 November 2011, pp. C007

NZOA, 2014. "Where are the audiences? Benchmark survey of New Zealanders' media consumption" Survey Prepared by Colmar Brunton For NZ ON AIR, June 2014. [WWW Document]. URL http://www.nzonair.govt.nz/document-library/2014-audience-research-full-report// (accessed 20.09.2014)

Pablo, 2012. "Showing the Money versus Making Numbers Work” KiwiPolitico blog post 3 May 2012. [WWW Document]. URL http://tinyurl.com/jqjy2bl (accessed 10.06.2016)

Pagani, J., 2014a. "Your choice: Look past trickery and deals and go with gut feeling" The New Zealand Herald [Auckland, New Zealand] 18 September, pp. A014

Pagani, J., 2014b. "Silence befuddles voters" The New Zealand Herald [Auckland, New Zealand] 15 September 2014 pp. A014

Parata, H., 2011a. "Responsible energy development for jobs and growth" National Party Press Release 14 November 2011. [WWW Document]. URL http://tinyurl.com/gpkdf46 (accessed 08.06.2016)

Parata, H., 2011b. "Building Strong Communities" National Party Press Release 17 November 2011. [WWW Document]. URL http://tinyurl.com/j96dp2p (accessed 11.06.2016)

Parata, H., 2014. "Four New Partnership Schools To Open" 11 September 2014. [WWW Document]. URL http://tinyurl.com/hmgxdo7 (accessed 06.06.2016) 
Parker, D., 2011. "Why no answers on Crafar farms before election?" Labour Party Press Release 23 November 2011. [WWW Document] URL http://tinyurl.com/76oz6q9 (accessed 05.06.2016)

Peacock, C., 2016. "Media merger will change the news" Mediawatch online article 14 May 2016. [WWW Document] URL http://tinyurl.com/jzzzbad (accessed 14.09.2016)

Peters, T., 2014. "NZ pseudo-left group defends Mana-Internet Party alliance" World Socialist Web Site blog post. [WWW Document]. URL http://tinyurl.com/jamtgbo (accessed 23.05.2016)

Peters, W., 2011. "Peters: Tauranga Public Meeting" New Zealand First Press Release 15 November 2011. [WWW Document]. http://tinyurl.com/zfqyhly (accessed 22.05.2016)

Poata-Smith, E., 1997. "The Political Economy of Inequality between Maori and Pakeha”. In Rudd, C. and Roper, B.S. (eds), The political economy of New Zealand. Oxford University Press, Auckland, NZ.

Poata-Smith, E., 2005. "The Veneer Is Radical, But the Substance Is Not" Pacific Journalism Review, Vol. 11, No. 1, Apr 2005: pp. 211-217.

Pratt, J., 2007. Penal Populism. Taylor \& Francis.

Rashbrooke, M., 2015. Wealth and New Zealand. Bridget Williams Books.

Research New Zealand, 2011. "Same Sex Marriages" Research New Zealand Press Release 12 July 2011. [WWW Document]. URL http://tinyurl.com/jku7crw (accessed 10.07.2016)

Robertson, G., 2011a. "Key must say why he's so keen to revive ACT" Labour Party Press Release 15 November 2011. [WWW Document]. URL http://tinyurl.com/gqy2myv (accessed 22.05.2016) 
Robertson, G., 2011b. “National's hysteria won't wash” Labour Party Press Release 24 November 2011. [WWW Document]. URL http://tinyurl.com/zaqal86 (accessed 08.06.2016)

Robertson, G., 2011c. "Labour's campaign keeps the issues centre-stage" Labour Party Press Release 25 November 2011. [WWW Document]. URL http://tinyurl.com/jsv7hef (accessed 15.06.2016)

Rosenberg, B. 2010. "Real wages and productivity in New Zealand". Paper presented for Labour, Employment and Work in New Zealand, Wellington. [WWW Document]. URL https://ojs.victoria.ac.nz/LEW/article/view/1714/1557 (accessed 21.08.2016)

Roy Morgan, 2014. "New Zealand's biggest problems are Economic Issues (41\%)..." Roy Morgan blog post 29 August 2014. [WWW Document]. URL http://tinyurl.com/zrcu5ng (accessed 23.05.2016)

Rutherford, H., 2013. "Two-thirds of voters oppose asset sales" Stuff online article 13 December 2013. [WWW Document]. URL http://tinyurl.com/gl2jwds (accessed 19.06.2016)

Rudd, C., Roper, B.S., 1997. The political economy of New Zealand. Auckland, NZ: Oxford University Press.

Ryall, S., Blumenfield, S., 2014. "The state of New Zealand Union membership in 2014" Centre for Labour, Employment and Work: Victoria University. [WWW Document]. URL http://tinyurl.com/joucyqj (accessed 30.05.2016).

Ryall, T., 2011. "Immunisation targets ramped up for child health" National Party Press Release 17 November 2011. [WWW Document]. http://tinyurl.com/htagopa (accessed 22.05.2016)

Scherer, K., 2011. "Burning Questions" Business_ Herald [Auckland, New Zealand] 18 November 2014, pp. K012

Satherly, D., 2016. "John Key blames Helen Clark for housing crisis” Newshub article 29 August 2016. 
[WWW Document]. URL http://tinyurl.com/zbxwror (accessed 12.09.2016)

Sider, G., 1997. Against Experience: The Struggles for History, Tradition and Hope Among a Native American People, in Between History and Histories. Toronto: University of Toronto Press

Sio, S.W., 2014. "All Black-Samoa game a win for fans" Labour Party Press Release 9 September 2014. [WWW Document]. URL http://tinyurl.com/hmgugn7 (accessed 06.06.2016)

Smith, D., 2014a. Criminal Injustice: Maori, Racism and Mass Incarceration. Wellington, NZ: International Socialist Organisation Aotearoa / New Zealand.

Smith, N., 2014b. "Partnerships, Pests and Oceans Focus of National's Conservation Policy" National Party Press Release 13 September 2014. [WWW Document]. URL http://tinyurl.com/z4neu46 (accessed 06.06.2016)

Smith, N., 2014c. "\$90,000 for kea conservation" National Party Press Release 15 September 2014. [WWW Document]. URL http://tinyurl.com/go84tjv (accessed 11.06.2016)

Statistics New Zealand, 2013. "Skill Levels of Zealand Jobs" Statistics New Zealand online article 2 May 2013. [WWW Document]. URL http://tinyurl.com/okox9vd (accessed 06.11.15)

Statistics New Zealand, 2014a. "Non-voters in 2008 and 2011 General Elections: Findings from New Zealand General Social Survey" Statistics New Zealand online article 13 January 2014 [WWW Document]. URL http://tinyurl.com/mqd5pzv (accessed 19.08.15).

Statistics New Zealand, 2014b. "2013 Census QuickStats about housing" Statistics New Zealand online article 18 March 2014 [WWW Document]. URL http://tinyurl.com/jmpsbn3 (accessed 06.06.2016) 
Stemler, S., 2001. "An overview of content analysis" Practical Assessment, Research \& Evaluation, 7(17).

Stuff, 2012. "Key criticises show host over 'gay red top"' Stuff online article 5 November 2012 [WWW Document]. http://tinyurl.com/anmdxlk (accessed 22.05.2016)

Sykes, A., 2010. "The Politics of the Brown Table." Originally presented as Bruce Jesson Foundation Lecture 2010 [WWW Document]. URL http://www.converge.org.nz/pma/as051110.pdf (accessed 05.11.15).

Tahana, Y., 2011. "Election 2011: Mana Party does tiki tour to show up poor 'parasites'” The New Zealand Herald [Auckland, New Zealand] 25 Nov 2011. pp. A06

Tapaleao, V., 2014. "Choices lure Pasifika voters away from red” [Auckland, New Zealand] 10 Sep 2007

Te Heuheu, G., 2011. "Growing stronger, more vibrant Pacific communities" National Party press release 18 November 2011. [WWW Document]. URL http://tinyurl.com/z9x6q2e accessed $(18.09 .2016)$

TEU, 2013. "TEU submission on the PBRF Review" TEU blog post 16 December 2013. [WWW Document]. URL http://tinyurl.com/hyz6efs (accessed 16.06.2016)

Thompson, P., 2011. "Neoliberalism and the Political Economies of Public Television Policy in New Zealand." Australian Journal of Communication 38(3): pp. 1-16.

Civics and Media Project, 2016. Proceedings of The Civics and Media Project: A report on the three workshops held in 2015, May 2016, published by the McGuinness Institute.

Trevett, C., 2012. "Key 'not against' gay marriage" NZ Herald online article May 11 2012. [WWW Document]. URL http://tinyurl.com/73mucyr (accessed 21.08.2016) 
Trevett, C., 2014. "Gamemakers wreak havoc but leaders battle on" The New Zealand Herald [Auckland, New Zealand] 18 September 2014, pp. A031

Turia, T., 2011. "A Transformational Agenda needed for Aotearoa" Māori Party Press Release 24 November 2011. [WWW Document]. URL http://tinyurl.com/h5228t4 (accessed 21.05.2016)

TV3, n.d. "Inside Child Poverty: A Special Report" produced by Bryan Bruce for TV3, no date provided. [WWW Document]. URL http://tinyurl.com/ckan2j7 (accessed 21.09.2016)

Veracini, L., 2011. “Introducing Settler Colonial Studies”. Settler Colonial Studies (2011) 1: pp. 1-12.

Vowles, J., 2012. "Down, Down, Down: Turnout in New Zealand from 1946 to the 2011 Election." Paper for presentation at the Annual conference of the New Zealand Political Studies Association, $\begin{array}{lllll}\text { Wellington, } & \text { November } & 25-27 & \text { 2012. }\end{array}$ [WWW Document]. URL http://www.nzes.org/docs/papers/nzpsa 2012.pdf (accessed 21.08.2016)

Walters, L., 2015. "Labour's 'half-baked' property data turns Chinese buyers into 'scapegoats"' Stuff online article 11 July 2015. [WWW Document]. URL http://tinyurl.com/okw3s9d (accessed 05.06.2016)

Warner, M., 1993. Fear of a Queer Planet: Queer Politics and Social Theory. University of Minnesota Press

Watson, M.; Hartevelt, J., 2011. "Harawira quits Maori Party" Stuff online article 23 February 2011. [WWW Document]. URL http://tinyurl.com/jsypy9g (accessed 19.06.2016)

Keucheyan, M., 2015. “Ernesto Laclau: Constructing Antagonisms by Razmig Keucheyan” Verso Books online article 13 February 2015. [WWW Document]. URL http://tinyurl.com/z3gmhr4 (accessed 15.09.2016) 
Whyte, J., 2014a. "Speech - Jamie Whyte ACT Campaign Opening" ACT Press Release 7 September 2014. [WWW Document]. http://tinyurl.com/hjsb6sm (accessed 23.05.2016)

Whyte, J. 2014b. "The Letter: Beating the Media Blackout" ACT Press Release 9 September 2014. [WWW Document]. http://tinyurl.com/zkqbe46 (accessed 21.05.2016)

Whyte, J. 2014c. "Why are we letting Dotcom steal our election?" ACT Press Release 16 September 2014. [WWW Document]. http://tinyurl.com/zjmht8z (accessed 21.05.2016)

Whyte, J. 2014d. "ACT Final Election Rally" ACT Press Release 19 September 2014. [WWW Document]. http://tinyurl.com/jemh2z7 (accessed 21.05.2016)

Wilkinson, K., 2011. "Health and safety funding for safe Canterbury rebuild" National Party Press Release 15 November 2011. [WWW Document]. URLhttp://tinyurl.com/zdt7zgu (accessed 01.06.2016)

Williams, M., 2014. "Mike Williams: Higher voter turnout could topple Nats" NZ Herald online article 8 June 2014. [WWW Document]. URL http://tinyurl.com/gqmt4cm (accessed 17.08.2016)

Wilton, D., 2007. Word Myths: Debunking Linguistic Urban Legends. Oxford University Press

Workers Party, 2008. "Workers Party announces party list for 2008 election” Workers Party press releases 9 October 2008. [WWW Document]. URL http://tinyurl.com/p6zxdgb (accessed 08.05.15)

Young, A., 2014a. "Internet/Mana alliance discussed at conference" NZ Heralld online article 28 June 2014. [WWW Document]. URL http://tinyurl.com/gwb8qyd (accessed 21.08.2016)

Young, A., 2014b. "Moment of Truth gifts Team Key a late bounce in polls" The New Zealand 
Young, A., 2014c. "What's eating Labour? Just 12 days left to save campaign" The New Zealand Herald [Auckland, New Zealand] 08 September 2014, pp. A004

Zinn, H., 1991. Declarations of Independence: Cross-Examining American Ideology. Perennial Publishers.

Žižek, S., 1999. The Ticklish Subject: The Absent Centre of Political Ontology, Verso 
Appendix: Coding schedule

\begin{tabular}{|c|c|c|}
\hline 100: National \& ethnic & Frequency & Contextual notes \\
\hline \multicolumn{3}{|l|}{ 101: New Zealand(er) } \\
\hline \multicolumn{3}{|l|}{ 102: Kiwi } \\
\hline \multicolumn{3}{|l|}{ 103: Nation (national) } \\
\hline \multicolumn{3}{|l|}{ 104: Citizen } \\
\hline \multicolumn{3}{|l|}{ 105: Pakeha } \\
\hline \multicolumn{3}{|l|}{ 106: Māori } \\
\hline \multicolumn{3}{|l|}{ 107: Non-Māori } \\
\hline \multicolumn{3}{|l|}{ 108: Australia(n) } \\
\hline \multicolumn{3}{|l|}{ 109: Pacific (Pasifika) } \\
\hline \multicolumn{3}{|l|}{ 110: Samoa(n) } \\
\hline \multicolumn{3}{|l|}{ 111: Cook Islands } \\
\hline \multicolumn{3}{|l|}{ 112: Tonga(n) } \\
\hline \multicolumn{3}{|l|}{ 113: Niue(an) } \\
\hline \multicolumn{3}{|l|}{ 114: Fiji(an) } \\
\hline \multicolumn{3}{|l|}{ 115: Tokelau(an) } \\
\hline \multicolumn{3}{|l|}{ 116: Middle East(ern) } \\
\hline \multicolumn{3}{|l|}{ 117: Asia(n) } \\
\hline \multicolumn{3}{|l|}{ 118: Chinese } \\
\hline \multicolumn{3}{|l|}{ 119: Europe(an) } \\
\hline \multicolumn{3}{|l|}{ 120: British } \\
\hline \multicolumn{3}{|l|}{ 121: Africa(n) } \\
\hline \multicolumn{3}{|l|}{ 122: America(n) } \\
\hline \multicolumn{3}{|l|}{ 123: Migrant } \\
\hline \multicolumn{3}{|l|}{ 124: Refugee } \\
\hline \multicolumn{3}{|l|}{ 125: Foreign(er) } \\
\hline \multicolumn{3}{|l|}{ 126: International } \\
\hline 200: Economic & & \\
\hline
\end{tabular}




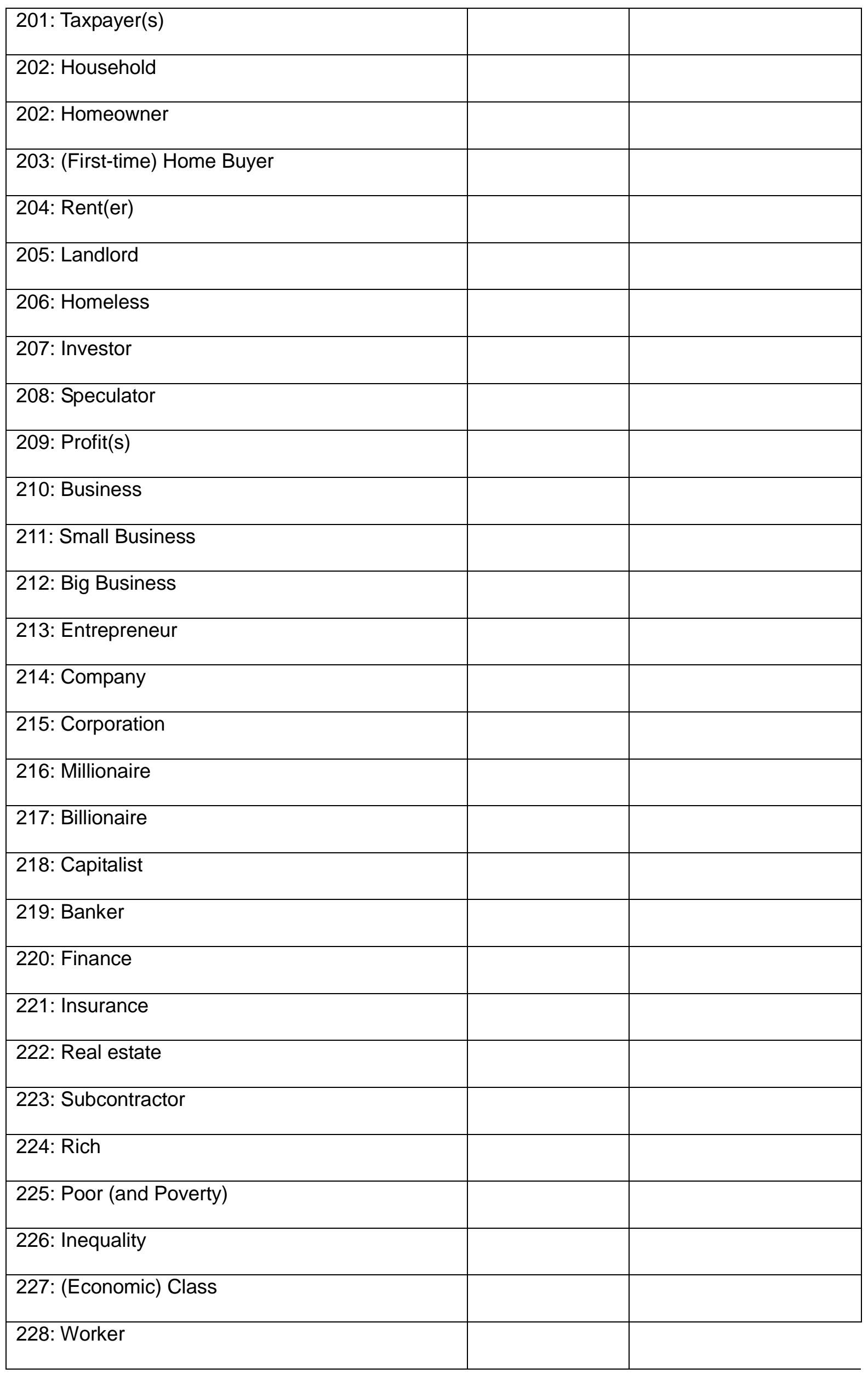




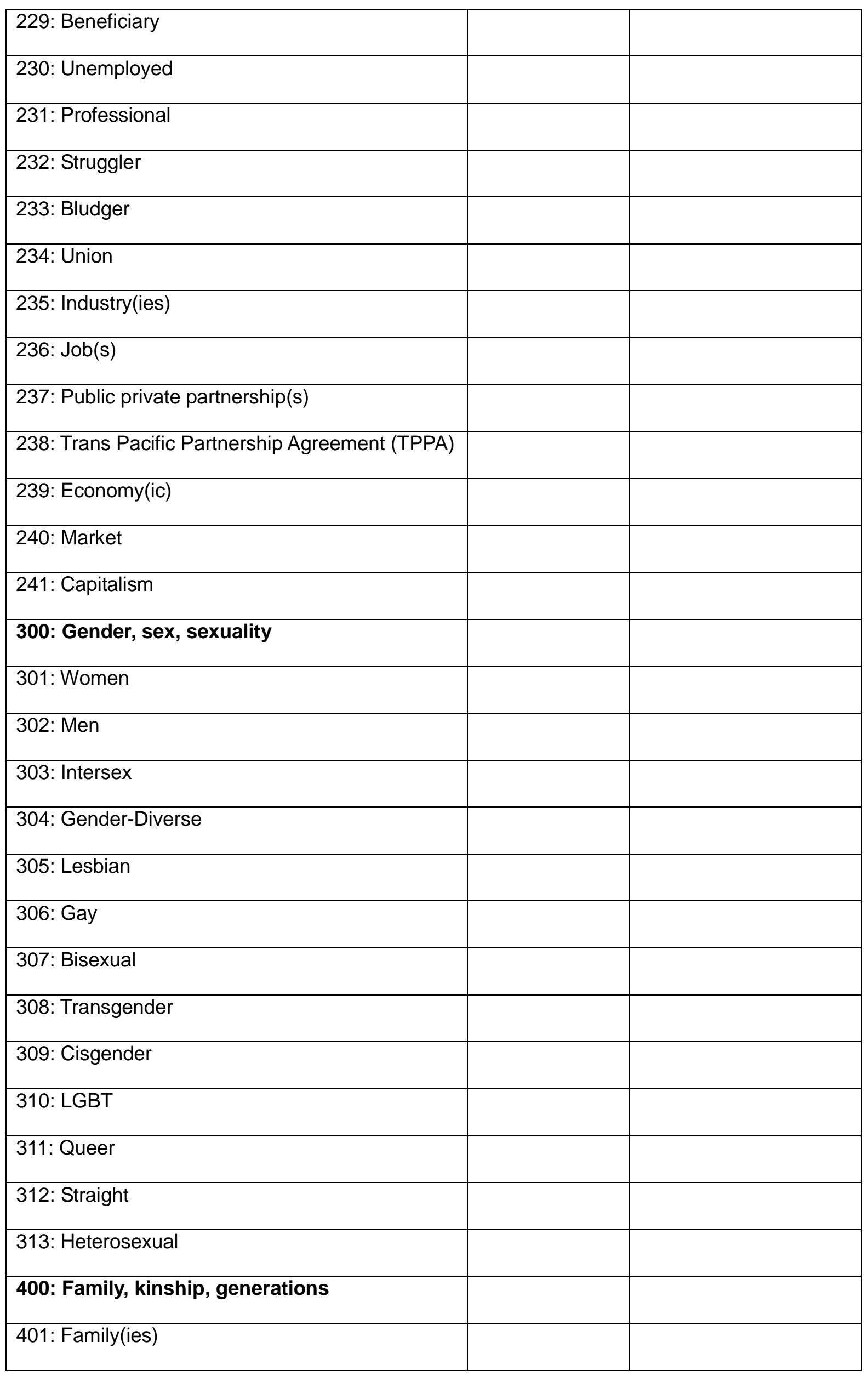




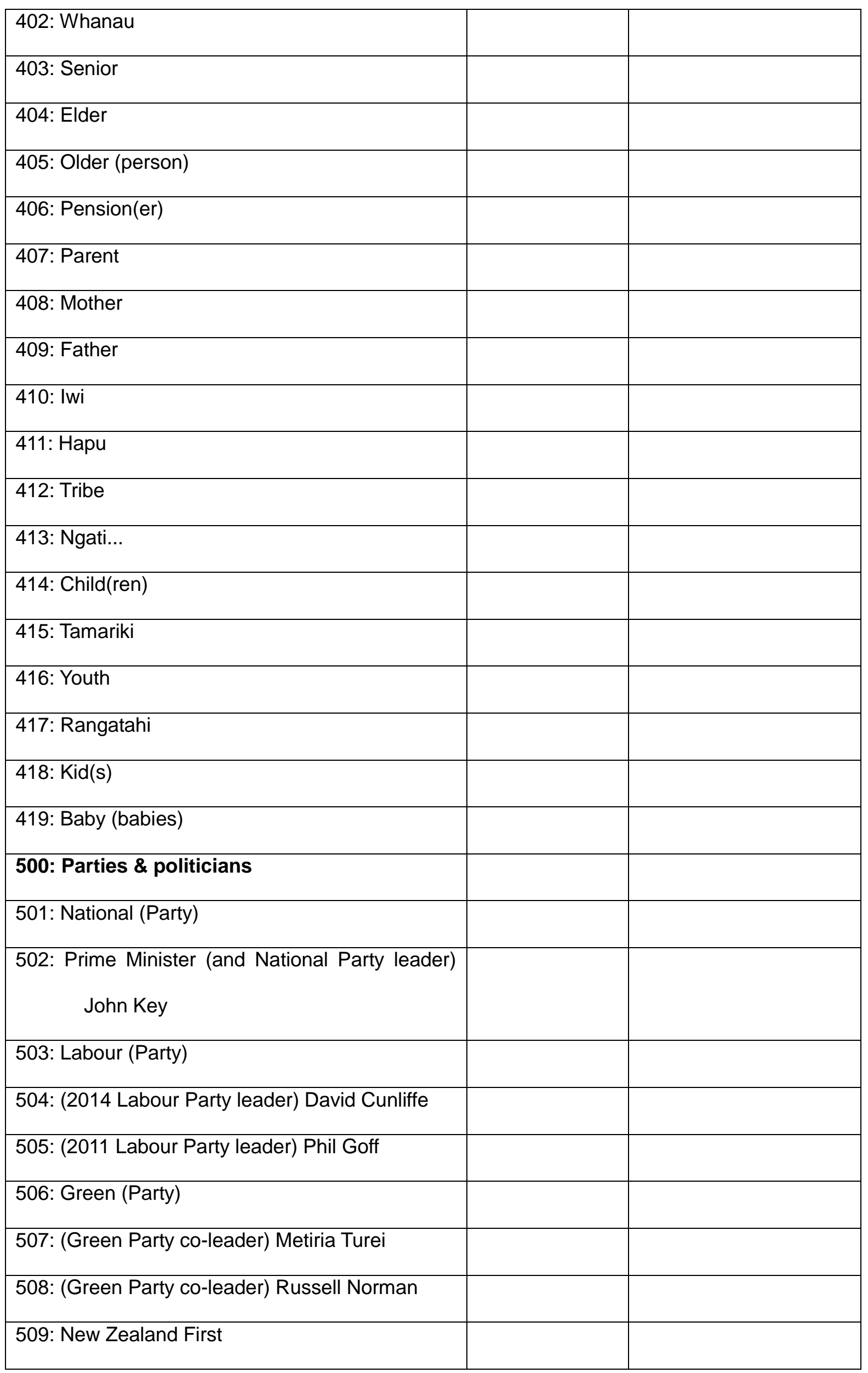


510: (New Zealand First leader) Winston Peter

511: Mana (Movement/Party)

512: (Mana Party leader) Hone Harawira

513: Internet (Party)

514: (Internet Party leader) Laila Harre

515: (Internet Party backer) Kim Dotcom

516: Internet Mana

517: Māori Party

518: United Future

519: (United Future leader) Peter Dunne

520: ACT

522: (2014 ACT leader) Jamie Whyte

523: (2011 ACT leader) Don Brash

524: Conservative (Party)

525: (Conservative Party leader) Colin Craig

526: Voter(s)

527: Non-voter(s)

528: Government

529: Opposition

530: (Wellington mayor) Celia Wade-Brown

531: (Auckland mayor) Len Brown

532: (Local) Council

533: Dirty politics (lower case)

534: Democracy

535: MMP

600: Corrections, Security, Criminality

601: Police

602: Justice (system)

603: Corrections 


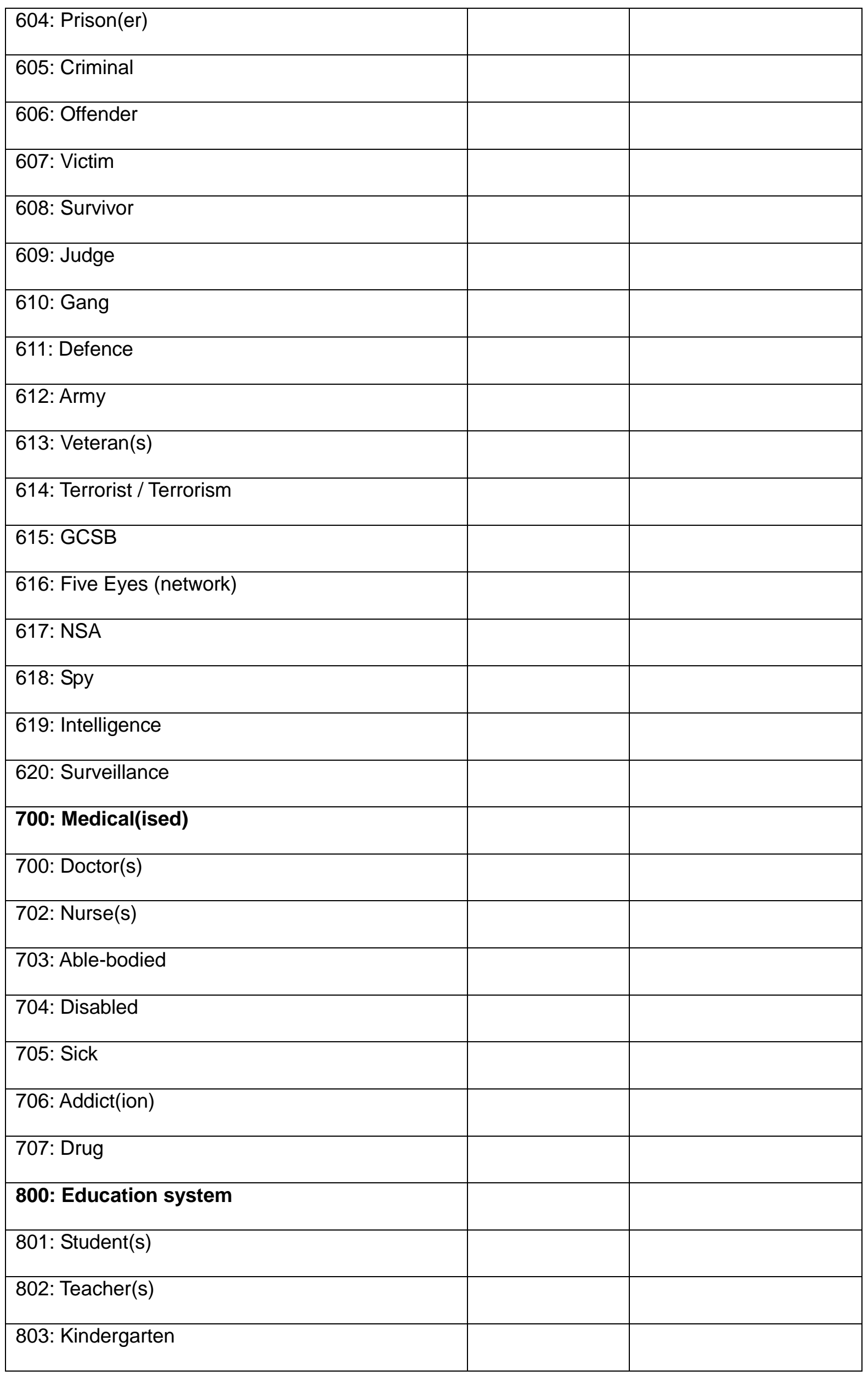




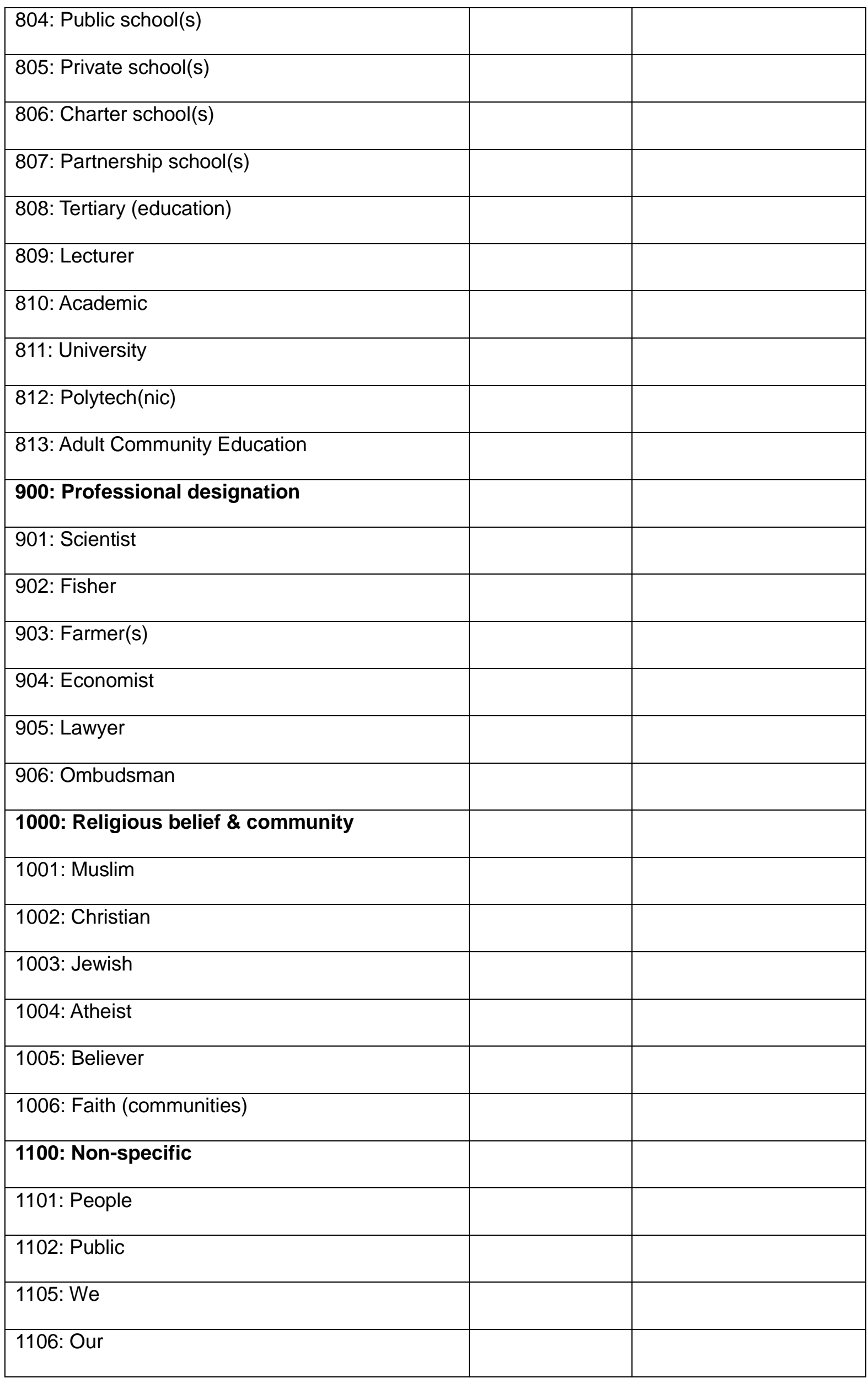




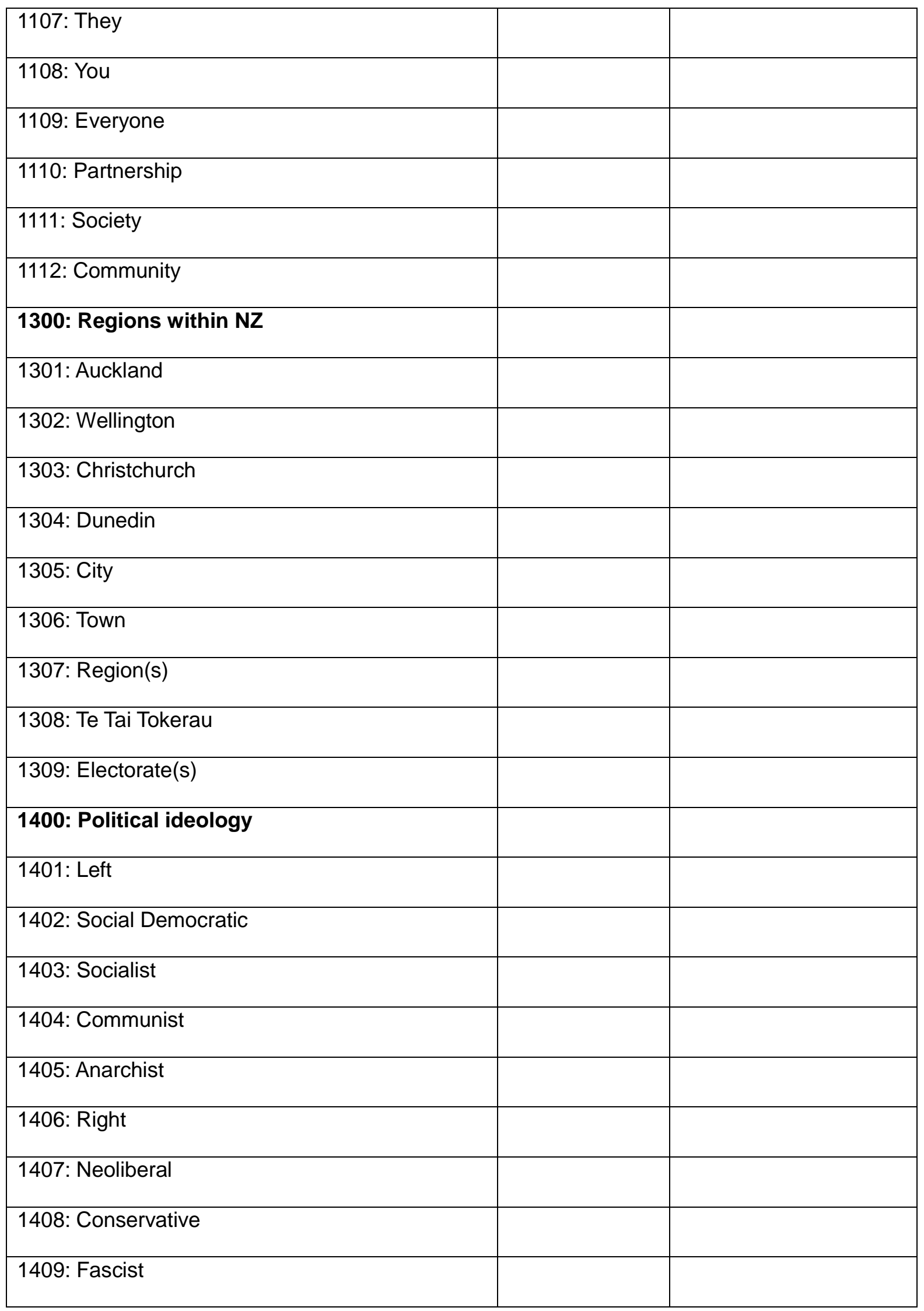

